1987

\title{
PLAN AMENDMENTS
}

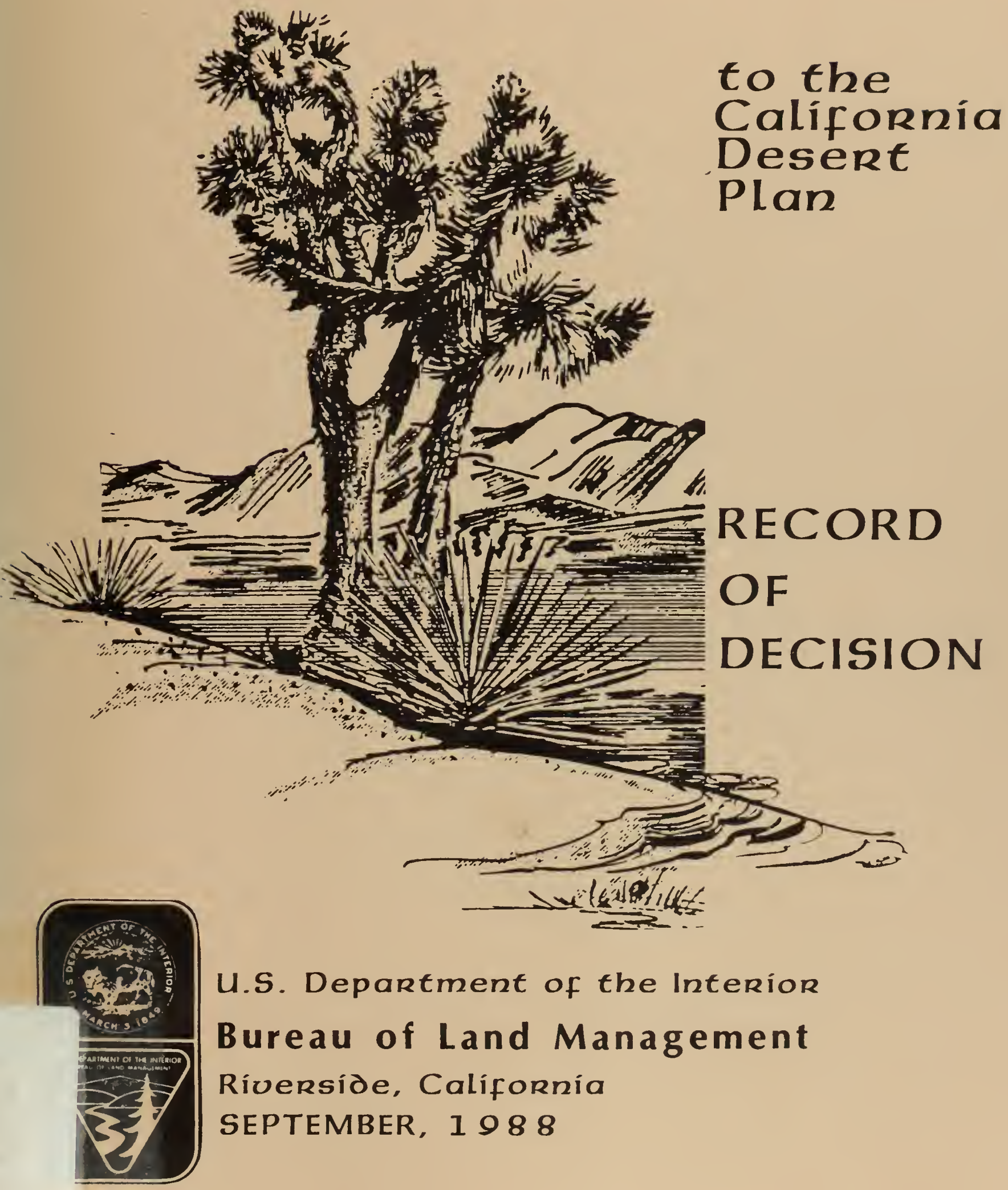


.

. 


\section{United States Department of the Interior}

BUREAU OF LAND MANA GEMENT

CALIFORNIA DESERT DISTRICT

1695 Spruce Street

Riverside, California 92507

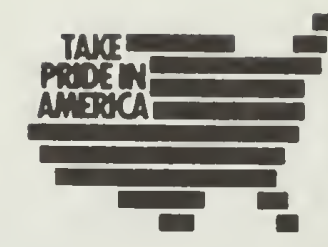

IN REPLY REFER TO:

1600

(CA-060.23)

AUG 311988

Memorandum

\section{BLM LIBRARY}

To: $\quad$ State Director (CA-910)

From: District Manager, California Desert

Subject: 1987 Amendment Decision

Enclosed is the Record of Decision for the 1987 amendment review of the California Desert Plan indicating my approval of the amendments.

The enclosed document is provided for your review and concurrence.

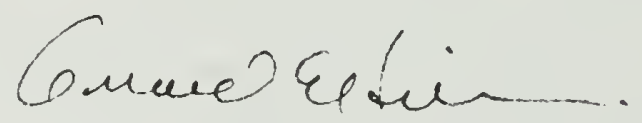

Enclosure

\section{BLM LIBRARY}

I concur with the California Desert District Manager's amendment decisions.

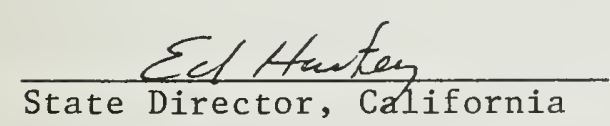

SEP 02198

Date

BLM LIBRARY

SC-32AA, BLDG. 50

DENVER FEDERAL CENTER

P. O. BOX 25047

DENVER, CO 80225-0047

Jake pride in your California Desert Conservation -trea

H Clational Treasure. 

In accordance with Chapter 7 of the California Desert Conservation Area (CDCA) Plan (1980) and with 43 CFR 1610.5-5, the Bureau of Land Management has conducted the seventh amendment review of the plan.

Proposals for amendments were accepted during a 31-day period from February 28 to March 31, 1987. Twenty-eight amendments were proposed by the public and by BLM staff. Each of the 28 amendments were screened by BLM management and by the California Desert District Advisory Council according to the following criteria:

1. Is the proposed amendment based upon new data not considered when the plan was developed?

2. Does the information represent a change in legal or regulatory mandate?

3. Is the supporting detail sufficient and the problem clearly stated so that the request can be considered?

4. Does the information represent a formal change in state or local government or agency plans?

of the twenty-eight (28) proposals sixteen (16) met the criteria. These sixteen (16) were combined into twelve (12) proposals and were analyzed by this enviconmental assessment. Of the remaining twelve (12) proposals, eleven (11) were rejected from consideration or will be handled by methods more appropriate than the amendment procedure, as described in Appendix B (tables B-1 and B-2). Consideration of the last proposal has been deferred to a later date.

The public comment period on the FA extended from October 16, 1987 to December 11, 1987. Thirty-two (32) written comments were received. Oral conments were accepted at the October 30, 1987 meeting of the Advisory Council in Ridgecrest

The preferred alternatives for all amendments are the same as those described in the enviconmental assessment.

Each amendment is described below and the environmentally prefered alternative is identified except when there is no significant difference. letter's received from the public, and responses to specific comments, are given in the Comments and Response section of this Record of Decision.

\section{Finding of No Significant Impact}

The environmental assessment identified no significant effects on the human or the natural environment. Therefore, an environmental impact statement is not r'equir'ed. 



\section{CALIFORNIA DESERT CONSERVATION AREA}

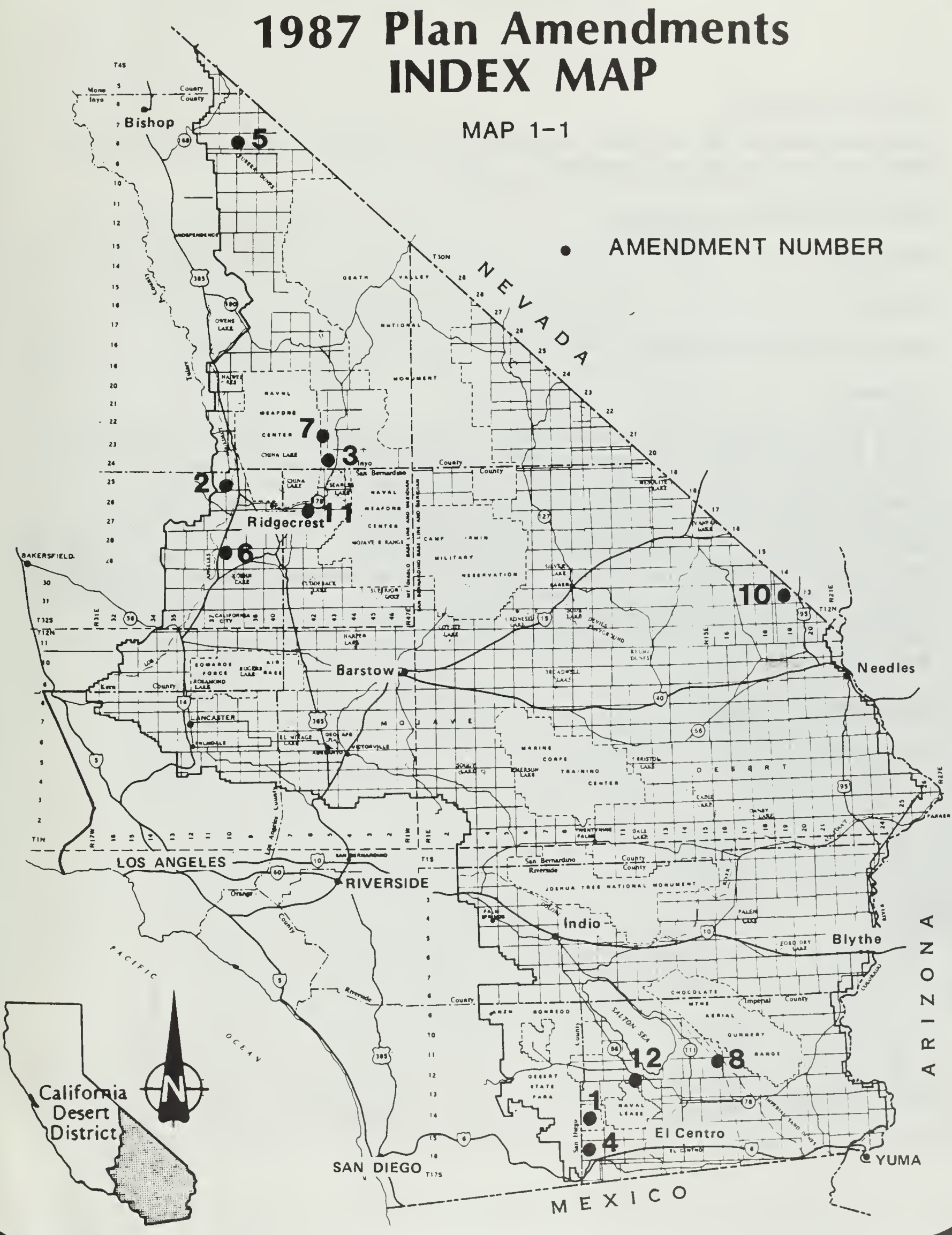


ACEC DESIGNATION FOR WEST MESA

\section{Proposed Amendment}

Designate an ACEC for wildlife, botanical, and cultural resource values in the West Mesa area of Imperial County.

\section{Other Alternatives Considered}

No Action.

\section{Decision}

Accept Proposed Amendment.

\section{$\underline{\text { Rationale }}$}

Since this area was within a U.S. Bureau of Reclamation withdrawal, leased to the U.S. Navy, it was not considered during the CDCA planning process. As part of a 1985 plan ammendment, field studies showed the area to have extremely high populations of the flat-tailed horned lizard (FTHL) and the largest amount of crucial FTHL habitat curcently existing. The FTHL is a BLM sensitive and U.S. Fish and Wildlife Service candidate species. Also present are cultural resources associated with the Lake Cahuilla shoreline and with localized ephemeral ponds. In addition there are two populations of Pilostyles thurberi and Astragalus crotalariae, two plant species listed by the California Native Plant Society. off-road vehicle use threatens all of these resources.

\section{Implementation Needs}

ACEC Management Plan.
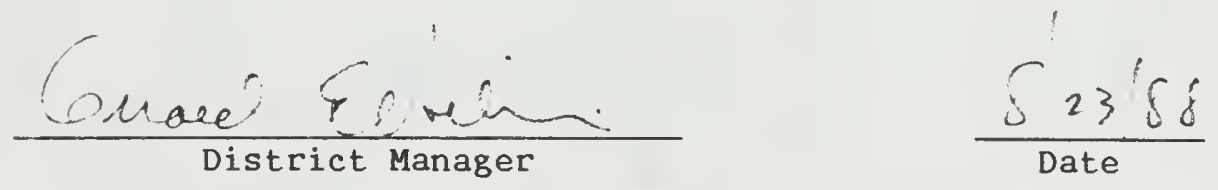


\section{AMENDMENT 1}

\section{New ACEC-West Mesa (Imperial County)}

713 Class " $\mathrm{C}$ "
$\square$ Class " $\mathrm{I}$ "
$\square$ Class " $\mathrm{L}$ "
$\square$ Class " $\mathrm{M}$ "
$\square$ Unclassified (Navy Withdrawal)
Patented Land

Proposed ACEC Boundary

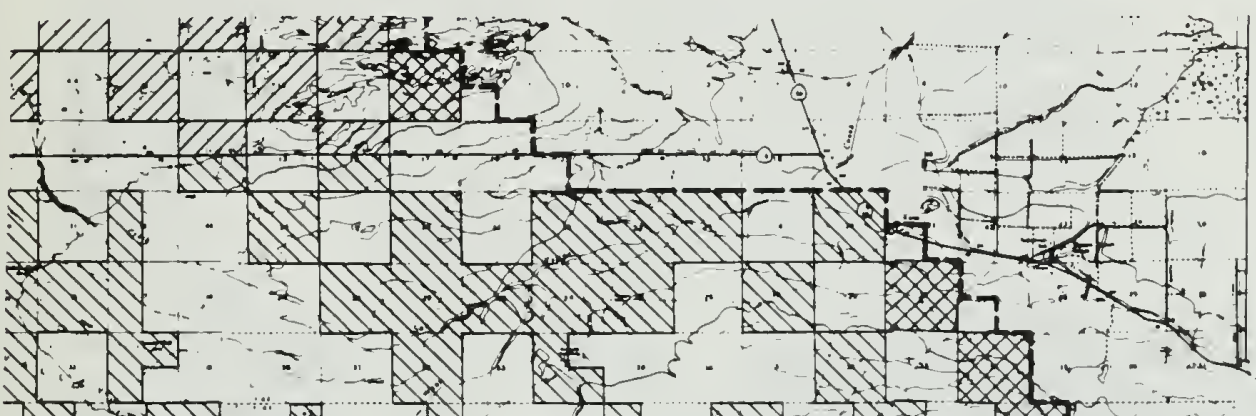

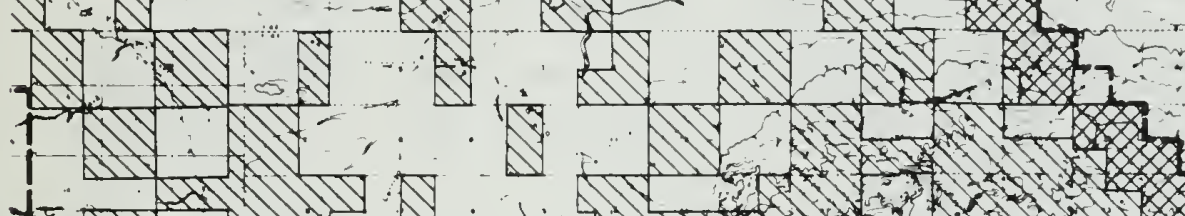
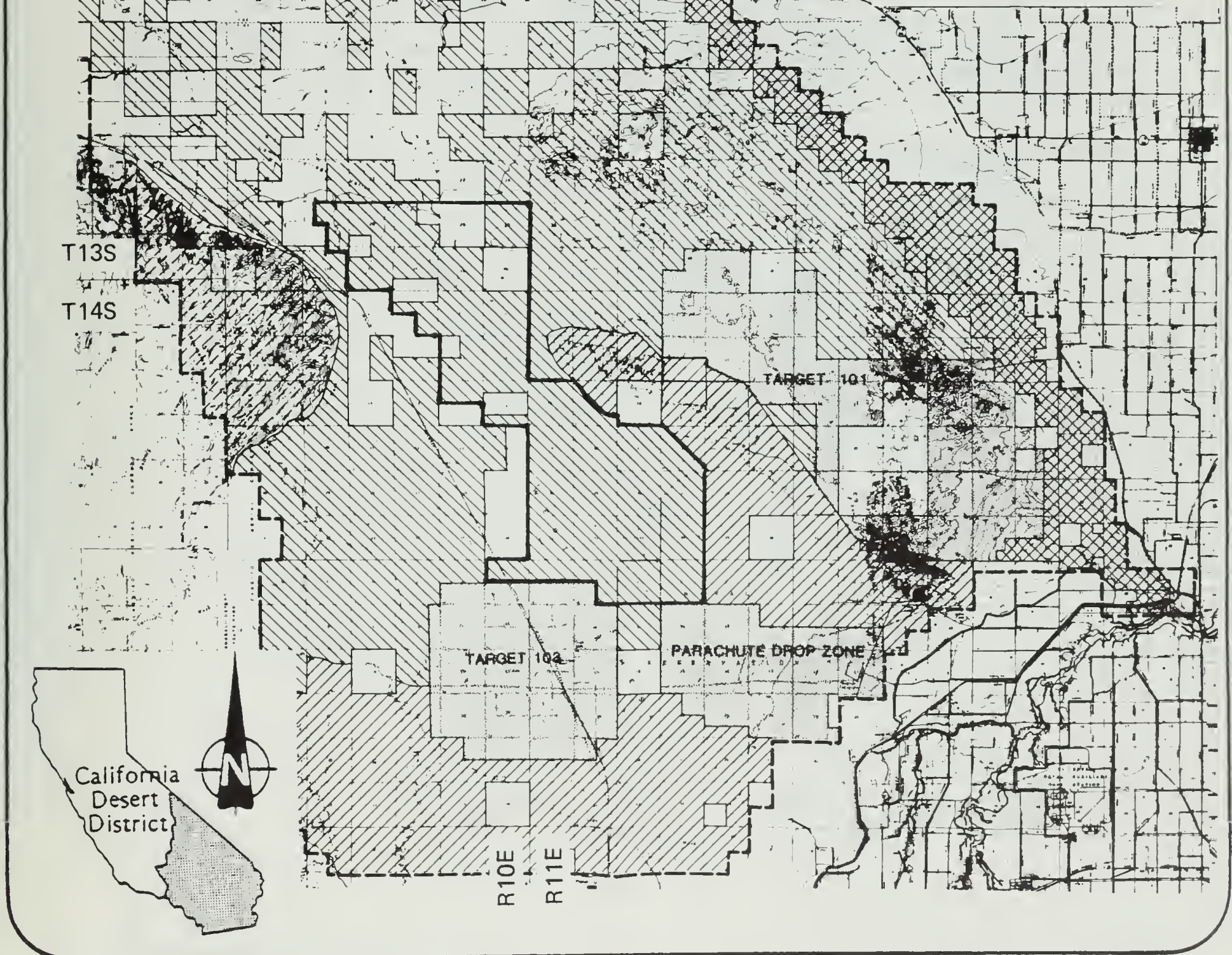
Proposed Amendment

Designate the entire drainage of Short Canyon, Kern County, as an ACEC.

\section{Other Alternatives Considered}

No Action.

Decision

Accept Amendment.

\section{Rationale}

The recently completed AMP for the Walker Pass Common Allotment requires construction of a fence across the botton of the canyon. This will eliminate grazing impacts on plants. An ACEC designation will have many benefits including measures to promote nature study and to provide aids for visitor interpretation.

\section{Implementation Needs}

ACEC Management Plan.

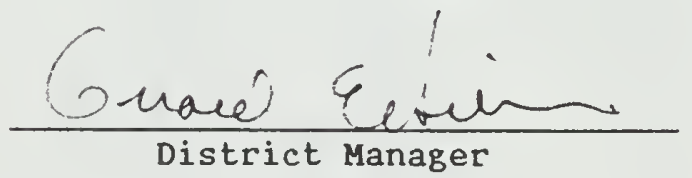

$$
\frac{\delta: 27 \delta 8}{\text { Date }}
$$



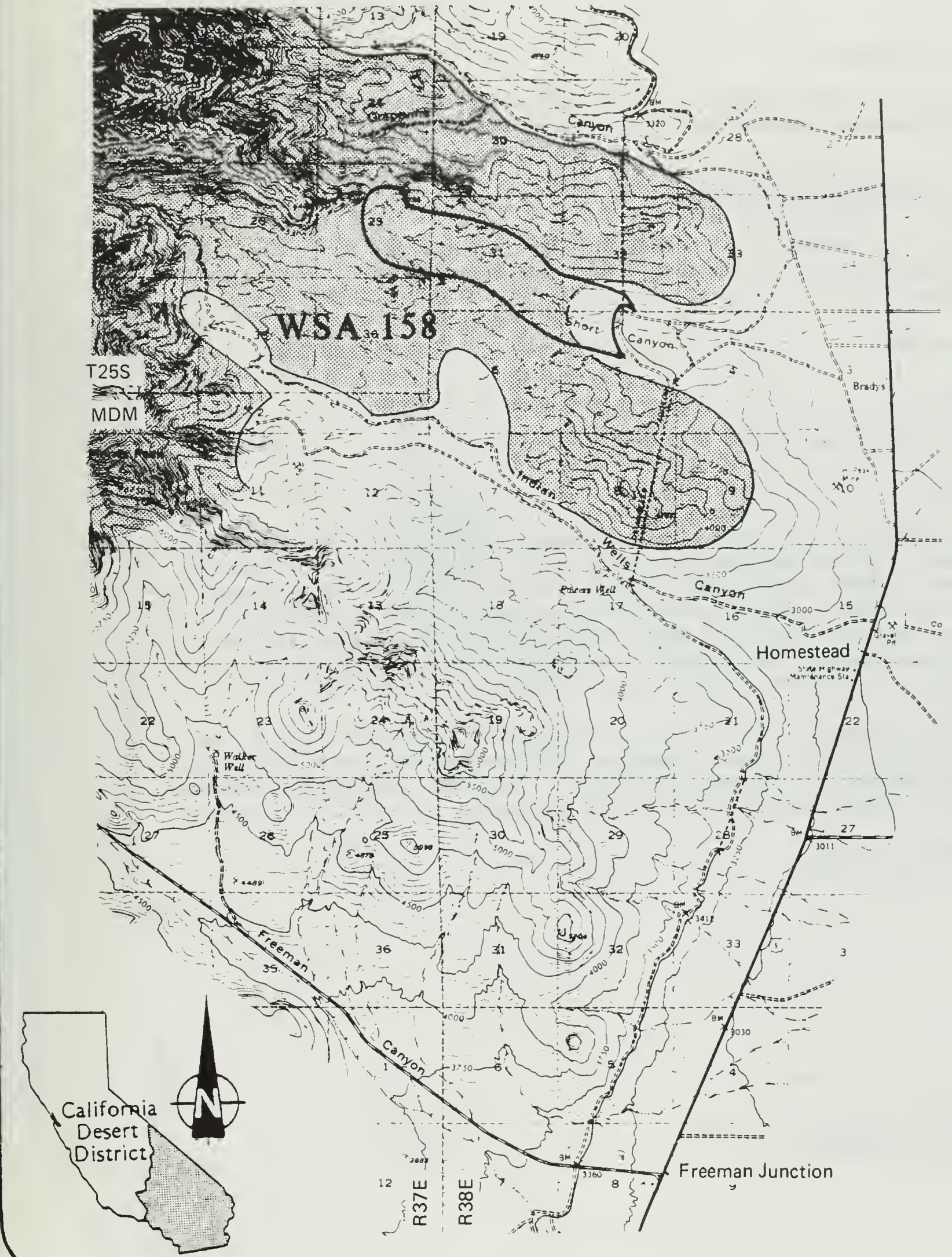


\section{Proposed Amendment}

Modify boundary to incorporate lands containing additional springs, riparian habitat and scenic resources and to delete the disturbed area around the Ruth Mine.

\section{Other Alternatives Considered}

B. Modify the boundary to include only the Great Falls Basin area; the northern portion of the ACEC, which includes Homewood Canyon, would be deleted.

C. No action.

\section{$\underline{\text { Decision }}$}

Accept Proposed Amendment.

\section{Rational}

The BLM's Great Falls Basin ACEC Management Plan recomended the proposed amendment. The current boundary does not include important habitat for the Inyo brown towhee, but it does include the unsightly Ruth Mine area. The areas to be added contain springs and riparian habitat which are important to the towhee and are presently being impacted by public activities such as uncontrolled vehicle use, camping and trash disposal. Removal of the Ruth Mine would increase the overall scenic integrity of the ACEC.

The first alternative was not acceptable. The northern portion is not primarily a residential zone, and the ACEC applies only to public lands. Critical habitat is a formal designation. The ACEC designation creates priority for BLM to develop protective management plans for the habitat.

\section{Implementation Needs}

None.

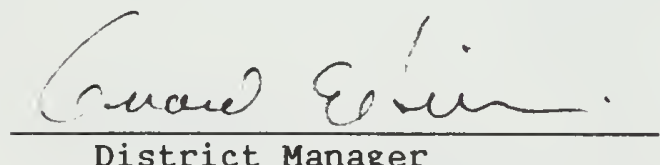

District Manager

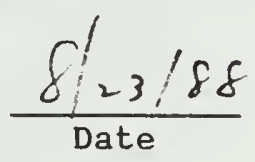




\section{AMENDMENT 3}

\section{Great Falls Basin/ Argus Range ACEC}

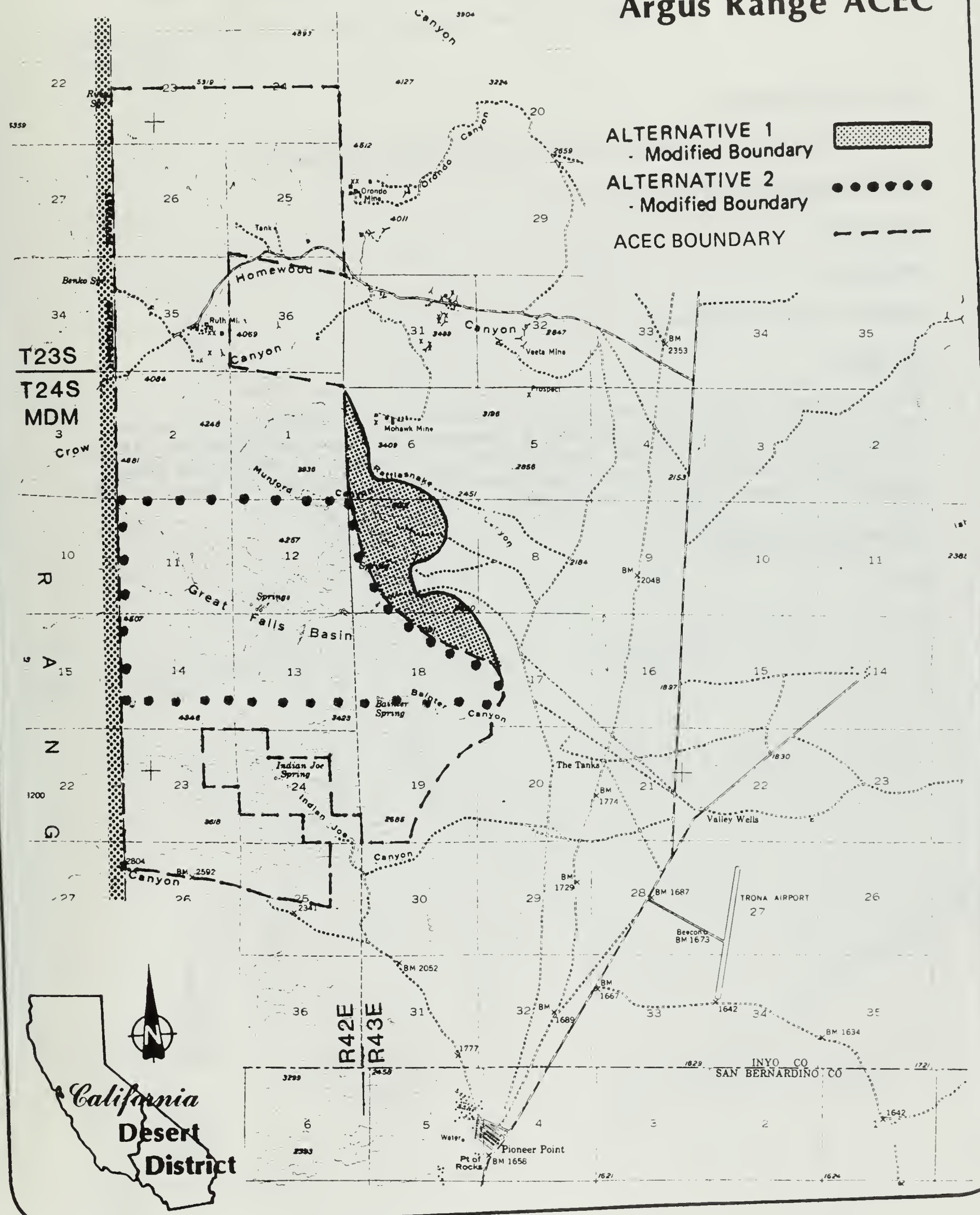


AMENDMENT FOUR

DELETE COYOTE MOUNTAINS ACEC

\section{Proposed Amendment}

Delete the current designation for the Coyote Mountains ACEC.

\section{Other Alternatives Considered}

No Action.

\section{Decision}

Accept Proposed Amendment.

\section{Rationale}

The Coyote Mountains ACEC was initially accorded this status based upon best available data. Prior to preparing a management plan, a sample investigation of the ACEC was conducted and predicted values as noted in the Desert Plan could not be verified. Cultural resources appear too sparse and insignificant compared to others found in the desert.

\section{Implementation Needs}

None.

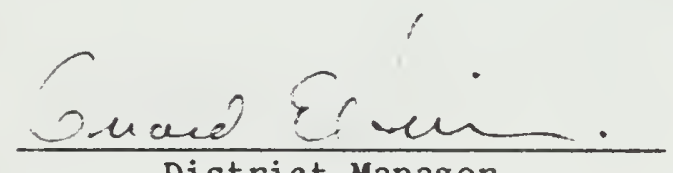

District Manager

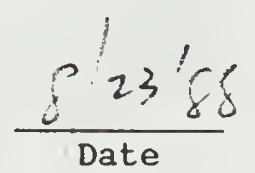


ACEC Boundary

Coyote Mountains ACEC

ALTERNATIVE $\boldsymbol{A}$

Delete ACEC

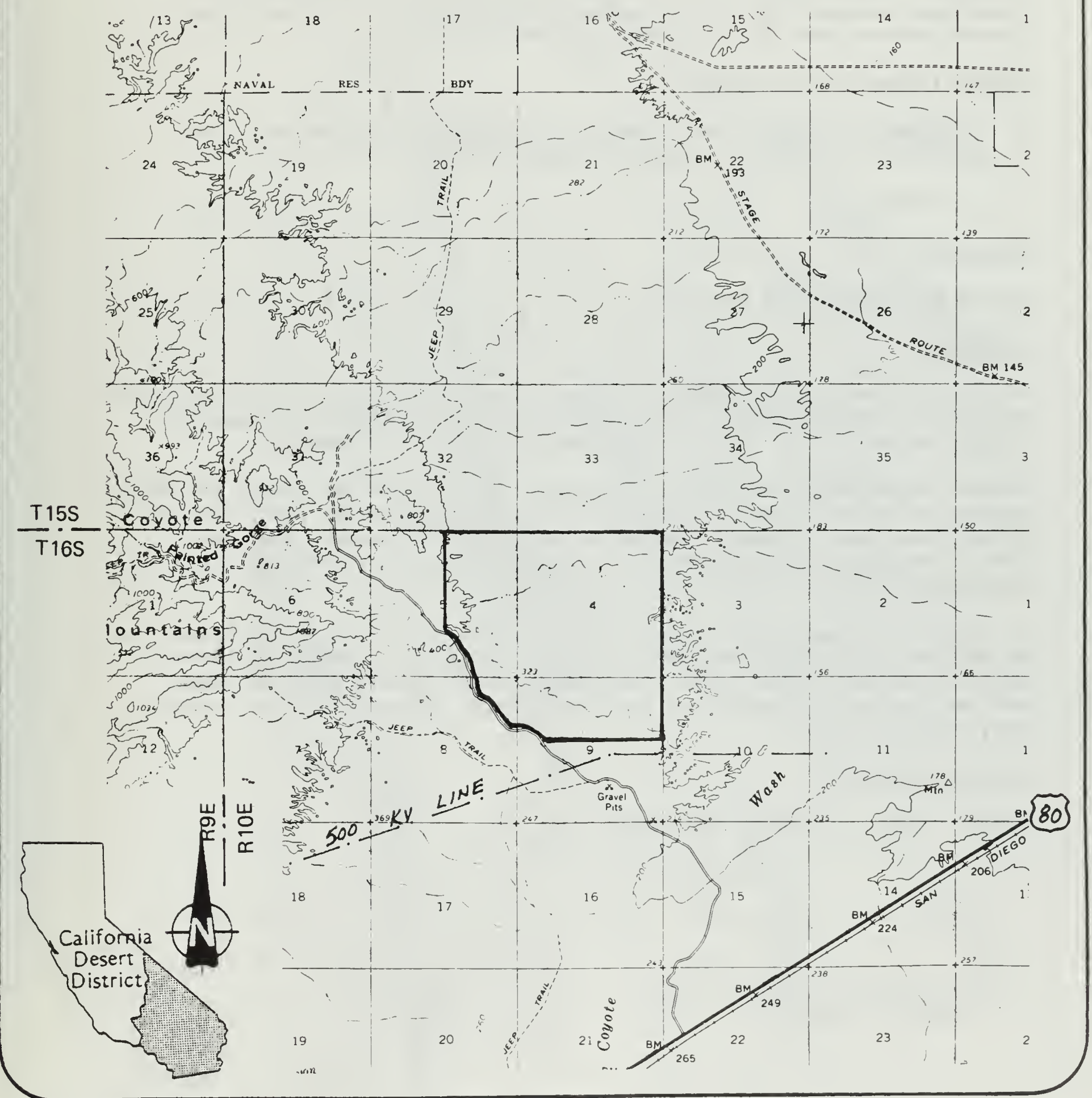




\section{Proposed Amendment}

Designate six (6) habitat management areas (HMA) in Mono and northern Inyo counties. These would be the East Slope White Mountain HMA; Soldier Pass-Piper Mountain HMA; Sylvania Mountains HMA; Last Chance Range HMA; Cowhorn-Waucoba HMA; and the North Coso Range HMA.

\section{Other Alternatives Considered}

B. Designate four HMAs: East Slope White Mountain; Soldier Pass-piper Mountain; Last Chance Range and Cowhorn-Waucoba.

C. No action.

\section{Decision}

Accept the Alternative B.

\section{Rationale}

Four (4) of the six (6) areas, Soldier Pass/Piper Mountain, East slope White Mountains, Last Chance Range and Cowhorn-Waucoba, respectively, have the highest potential for habitat enhancement of the six (6) areas.

Bighorn sheep reintroductions are planned for the first two areas, for which BLM policy requires the preparation of a habitat management plan. The Last Chance Range has a bighorn population of about 100. An HMA plan for Cowhorn-Waucoba would complement the existing Inyo-White Mountains Deer Herd Management Plan.

As regards the proposed amendment, provided there is treatment of bighorn and upland game in the grazing AMPs, it is unlikely that an HMA plan for the Sylvania and North Coso Range would additionally enhance wildlife values. Further, energy development of the western side of the North Coso precludes many wildlife actions.

\section{Implementation Needs}

Prepare Four (4) Habitat Management Plans.

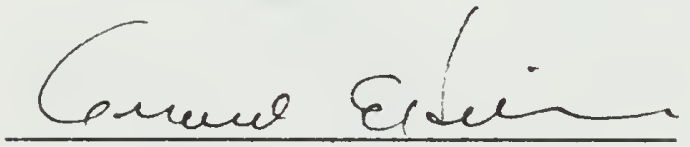

District Manager

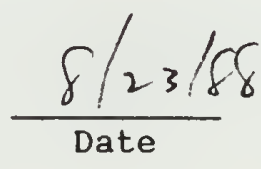




\section{Inyo/Mono Counties}

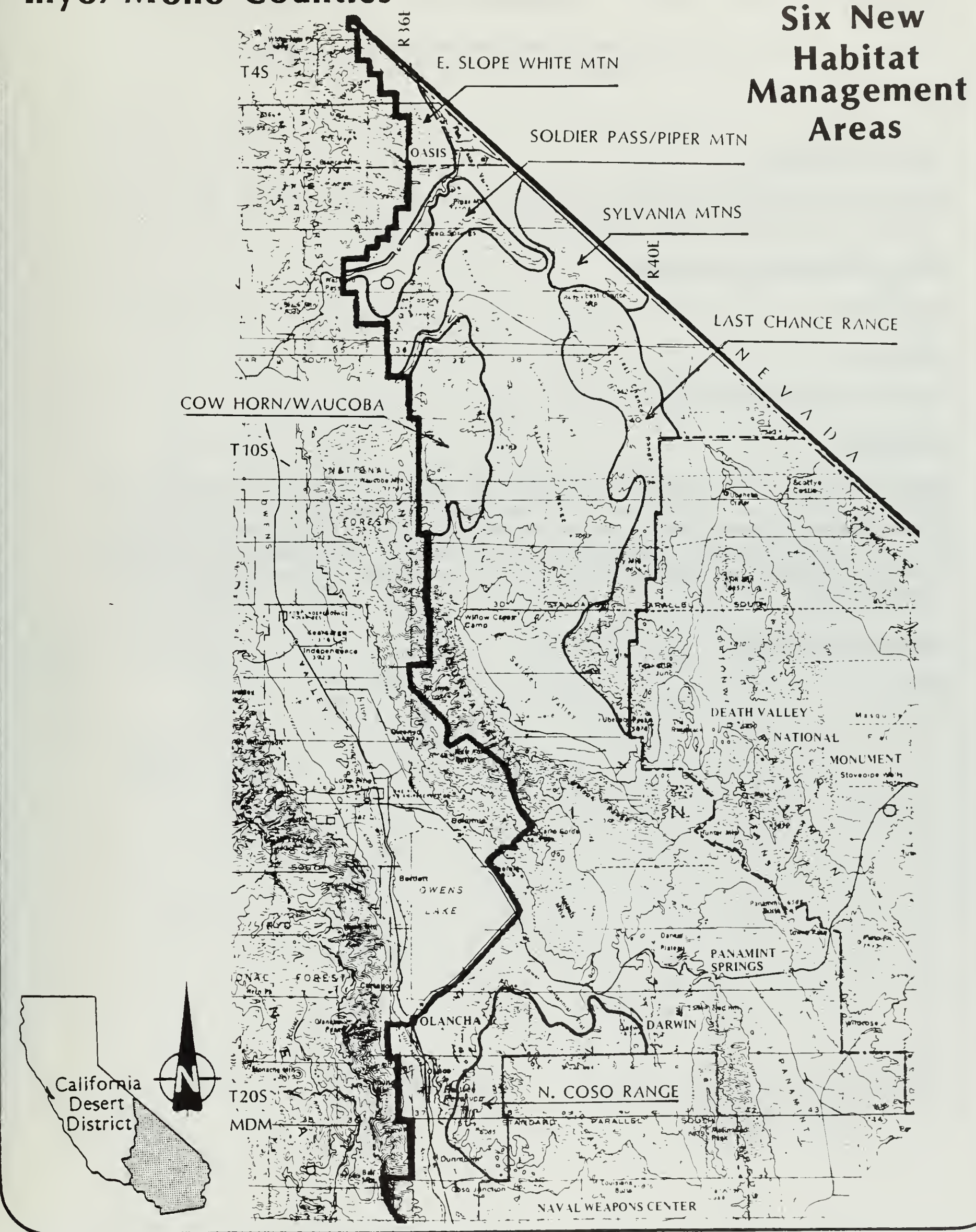

Establish

Six New

Management

Areas 
CHANGE MULTIPLE USE CLASS DESIGNATION OF 2,164 Acres

ADJACENT TO RED ROCK CANYON

Proposed Amendment

Change the multiple use class designation of 2,164 acres of land adjacent to Red Rock Canyon State Park from unclassified to Class L.

Other Alternatives Considered

No Action.

Decision

Accept Proposed Amendment.

Rationale

When the CDCA plan was adopted, the area was included within a Recreation and Public Purposes Act application. It has since been decided that the area will remain under BLM management. Since the adjacent area is designated Class L, it is consistent to designate this area as Class L. The area will continue to be managed by the BLM and the state Parks system under a memorandum of understanding.

\section{Implementation Needs}

None.
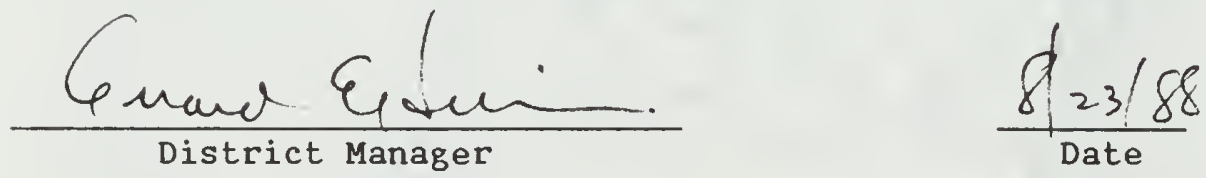


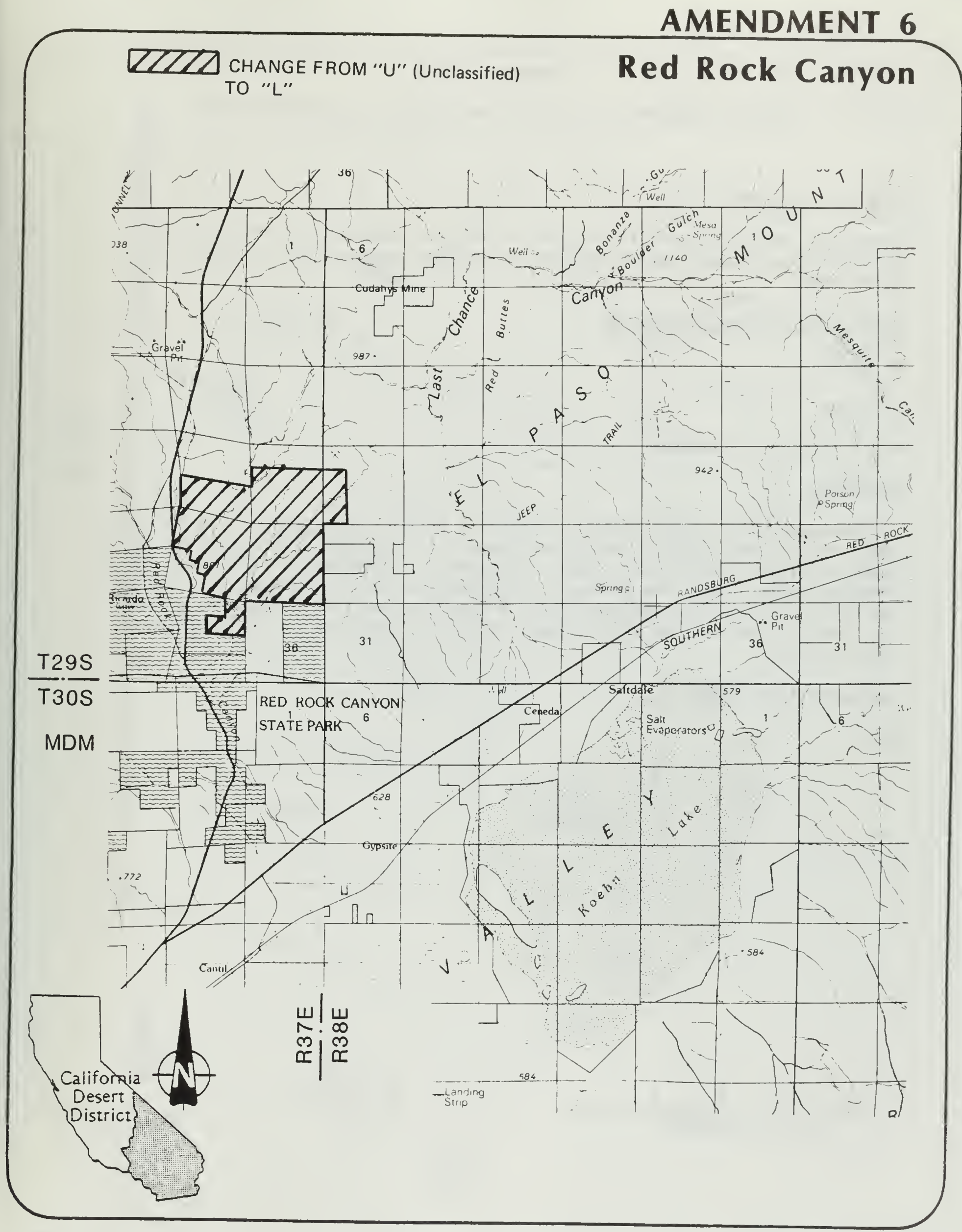




\section{Proposed Amendment}

Change the multiple use class of two parcels of land within Homewood Canyon from Class L to unclassified and delete the two parcels from the Great Falls Basin ACEC.

\section{Other Alternatives Considered}

No Action.

\section{Decision}

Reject Proposed Amendment.

\section{Rationale}

The Bureau cannot create private estates on public lands, especially when this would create inholdings in sensitive areas such as ACECs. Bureau policy is to acquire, rather than create, such inholdings. In the 1970s, the Bureau issued lifetime leases under the Mining Claim occupancy Act (now expired) to two of the three residents inside the ACEC. The lessees will be allowed to occupy the land for the rest of their lives. The third resident will be offered a lease as well.

\section{Implementation Needs}

None.
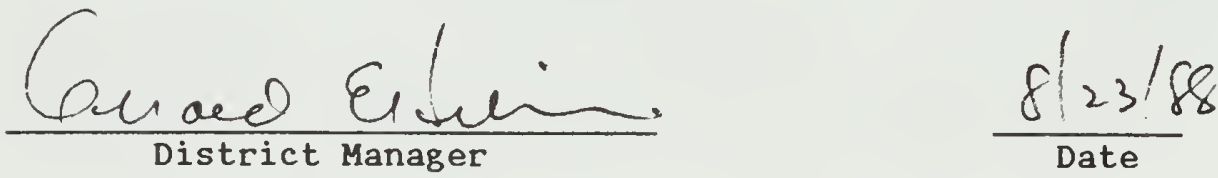


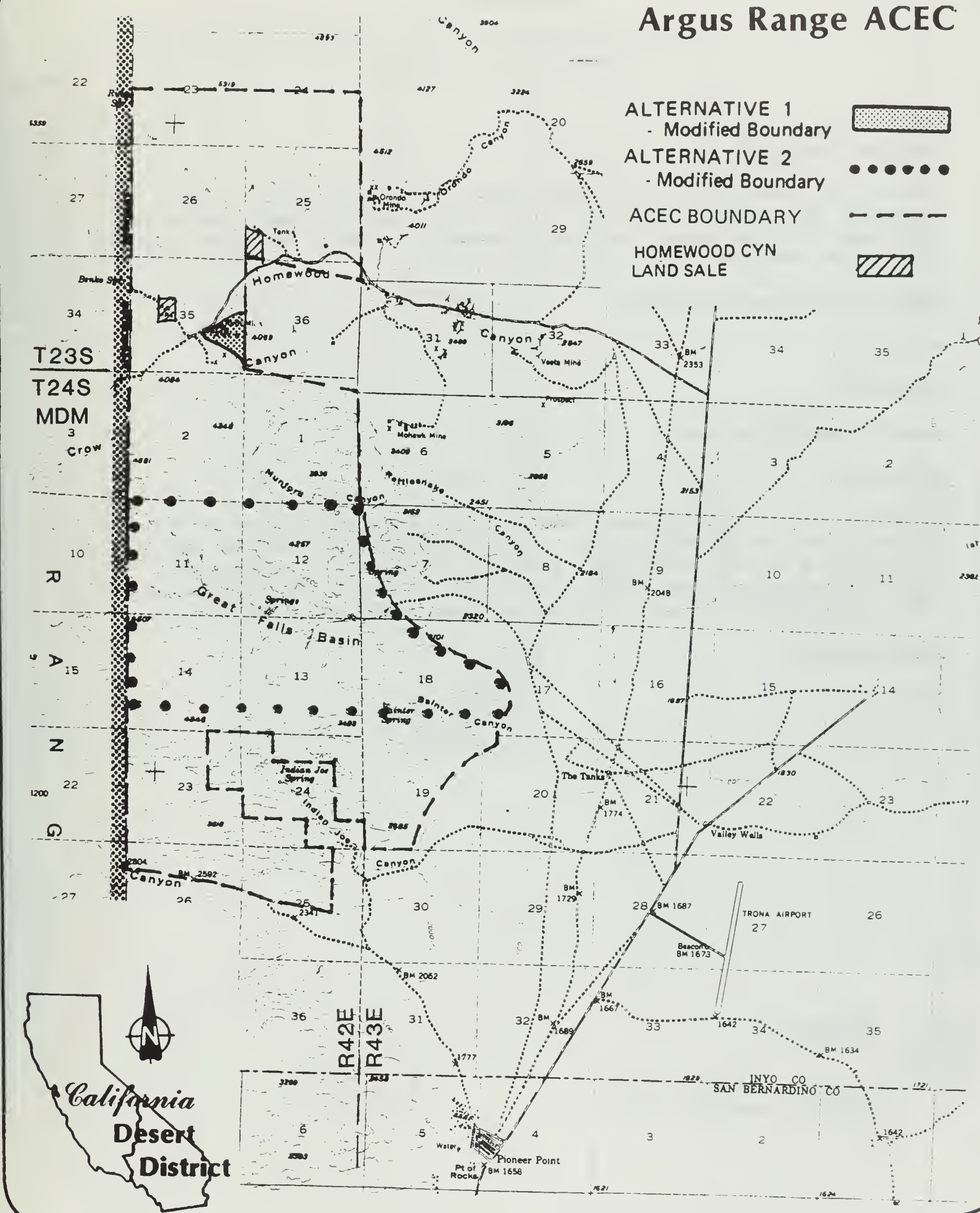


CHANGE MULTIPLE USE CLASS OF PARCEL ADJACENT TO COACHELLA CANAL

\section{Proposed Amendment}

Change T12S, RI6E, Section 6 from unclassified to Class L west of the Coachella ( 80 acres) and to Class I east of the Coachella Canal ( 800 acres). Redesignate vehicle access from "undesignated" to "limited to approved routes" west of the canal and "open" east of the canal.

\section{Other Alternatives Considered}

No Action.

\section{$\underline{\text { Decision }}$}

Accept Proposed Amendment.

\section{Rationale}

Recreationists using the Mammoth Wash open area use the part east of the Coachella Canal as a camping area. A Class I designation would be consistent with existing use and would enable possible development of recreational facilities proposed in the Imperial Sand Dunes Recreation Area Management plan. Current unclassified status leaves these lands open to disposal.

\section{Implementation}

None.
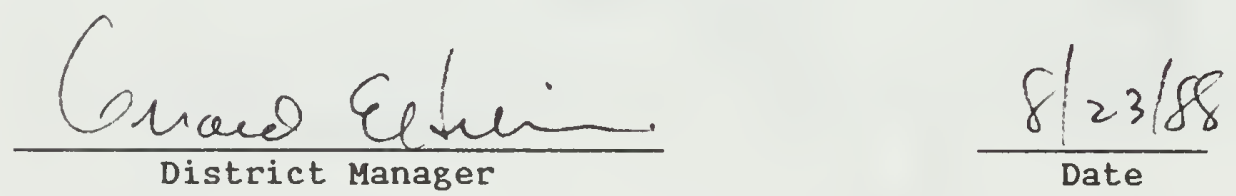


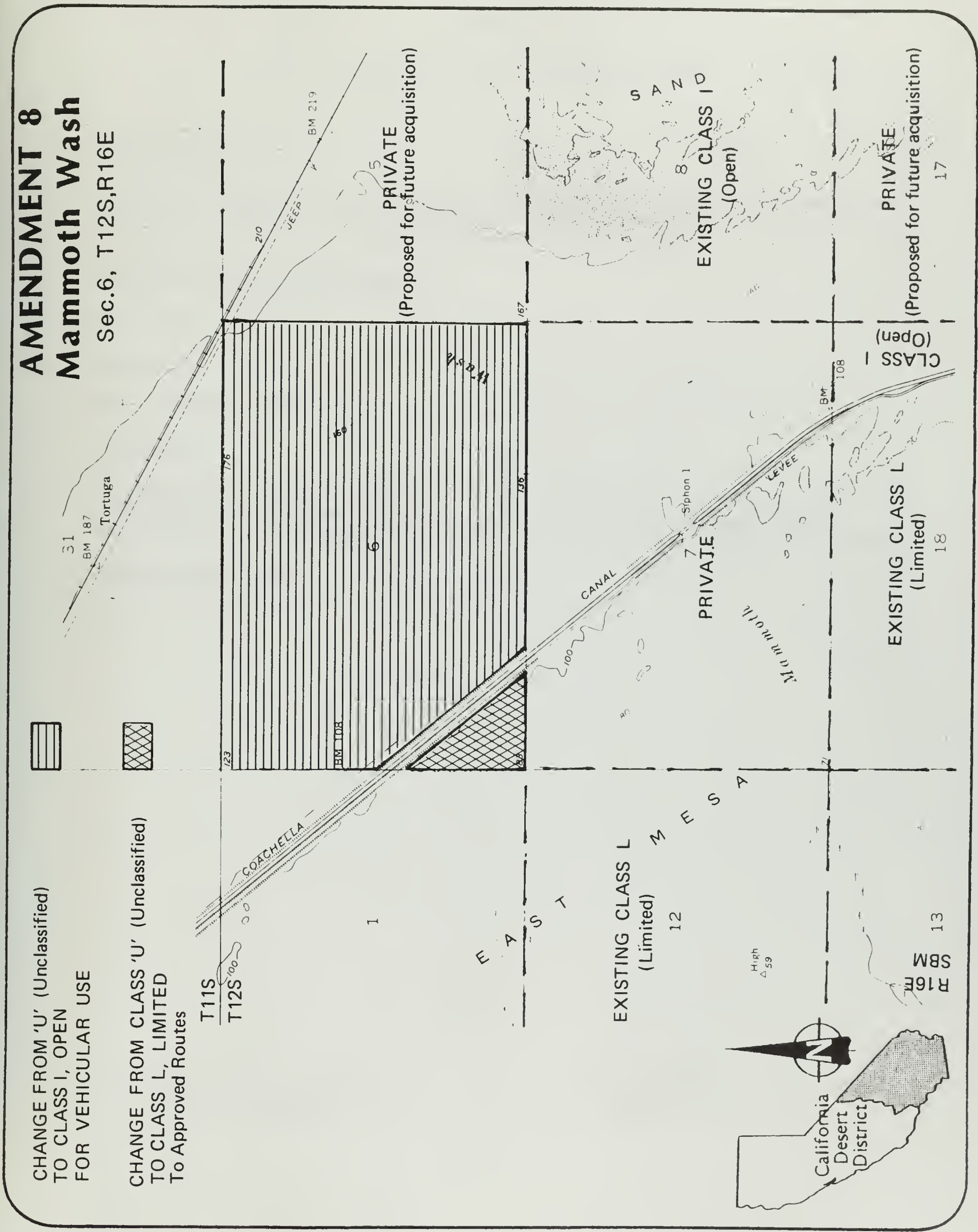





\section{AMENDMENT NINE}

ADD NEW GOAL FOR RECREATION ELEMENT

Proposed Amendment

Add the following as a new goal for the recreation element: "Encourage the use and enjoyment of desert recreation opportunities by special populations, and provide facilities to meet the needs of those groups."

\section{Other Alternatives Considered}

No Action.

Decision

Accept Proposed Amendment.

\section{Rationale}

The new goal would complement BLM's current efforts to provide access for the handicapped to developed public facilities. It would also give public emphasis to the development of interpretive materials for special populations.

Implementation Needs

None.
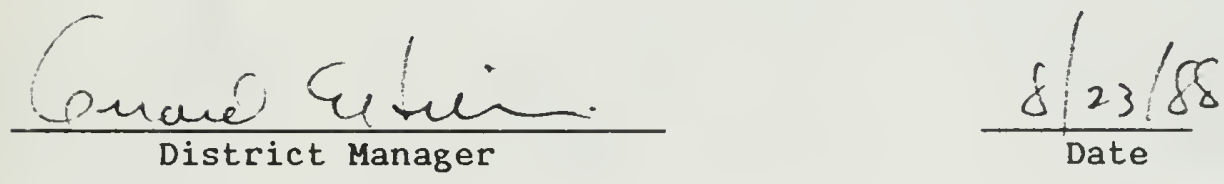
CHANGE PIUTE VALLEY ALLOTMENT FROM EPHEMERAL TO EPHEMERAL-PERENNIAL

\section{Proposed Amendment}

Change Piute Valley grazing allotment from ephemeral to ephemeral-perennial with a carrying capacity of 720 AUMs, all allocated to cattle.

\section{Other Alternatives Considered}

No Action.

\section{Decision}

Reject Proposed Amendment.

\section{Rationale}

Most of the perennial forage is located in the western portion of the allotment, in the Piute Range. This area is within a recommended-suitable WSA and has a resident bighorn sheep herd. If the perennial forage were to be utilized, the rancher's operation would have to be shifted into the Piute Range, resulting in resource conflicts. If the operation continued to utilize Piute Valley (an area of primarily ephemeral forage), it would lack the perennial forage base necessary to justify the change to ephemeral-perennial.

\section{Implementation Need}

None.
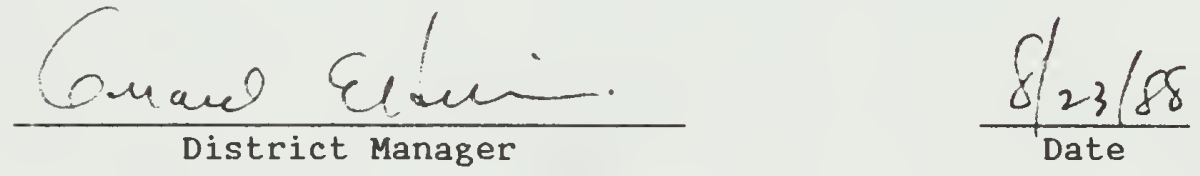


\section{AMENDMENT 10 Piute Valley Allotment}

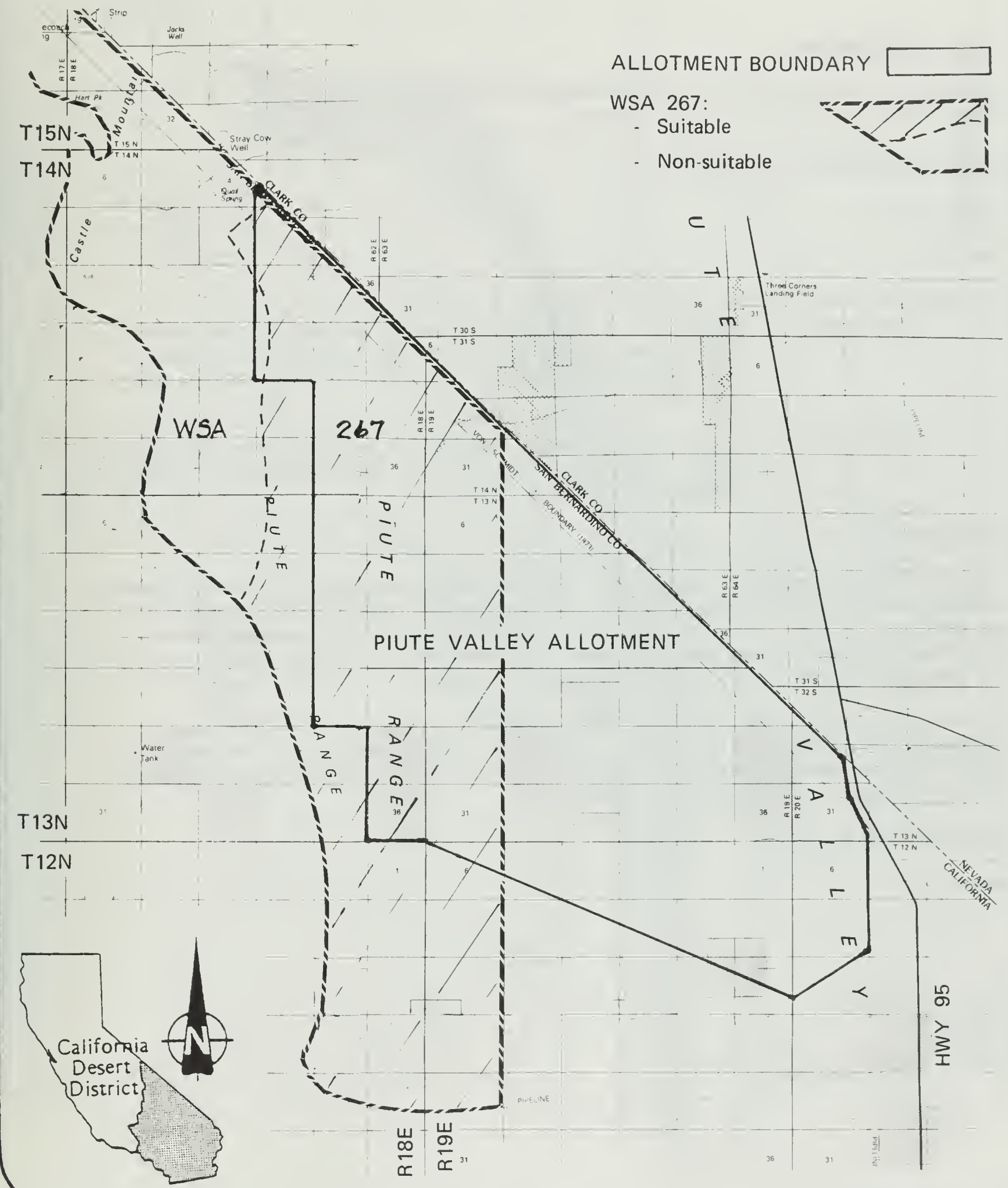


ESTABLISH NEW UTILITY CORRIDOR

FROM INYOKERN TO VICINITY OF TRONA

\section{Proposed Amendment}

Establish a new utility corridor from corridor A at Inyokern to the Kerr-McGee facilities in the vicinity of Trona.

\section{Other Alternatives Considered}

No Action.

\section{Decision}

Accept Proposed Amendment subject to two conditions:

Condition 1.: Electrical transmission towers (as well as any other facilities) would be limited to 125 feet in height within the Naval Weapons Center's C and G low flight corridors.

Condition 2.: New facilities must meet all Visual Resource Management (VRM) class objectives within the VRM class III lands southwest of Trona.

\section{$\underline{\text { Rationale }}$}

The Kerr-MCGee Chemical Corporation (KMCC) intends to construct a replacement water line ( 16 inch diameter) from existing well fields in Indian Wells valley to KMCC facilities in Searles Valley. In addition, a new brackish water pipeline (20 inch diameter) would be built from KMCC's Valley Wells facility to proposed Argus Cogeneration Expansion facility.

The City of Ridgecrest also plans to construct a pipeline from the Naval Weaspons Center to KMCC in Trona. Finally, the Indian Wells water Agency plans to construct pipelines to transport water from the Los Angeles Aqueduct to the Ridgecrest metropolitan area.

\section{Implementation}

None.
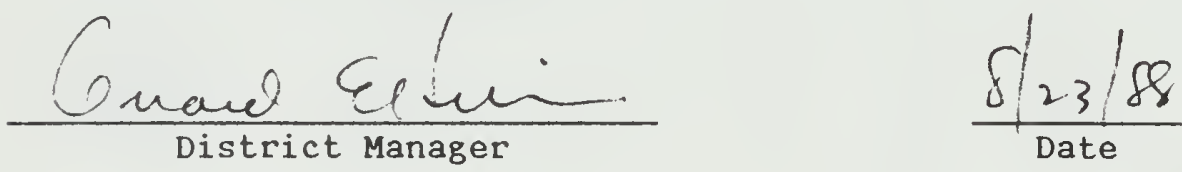


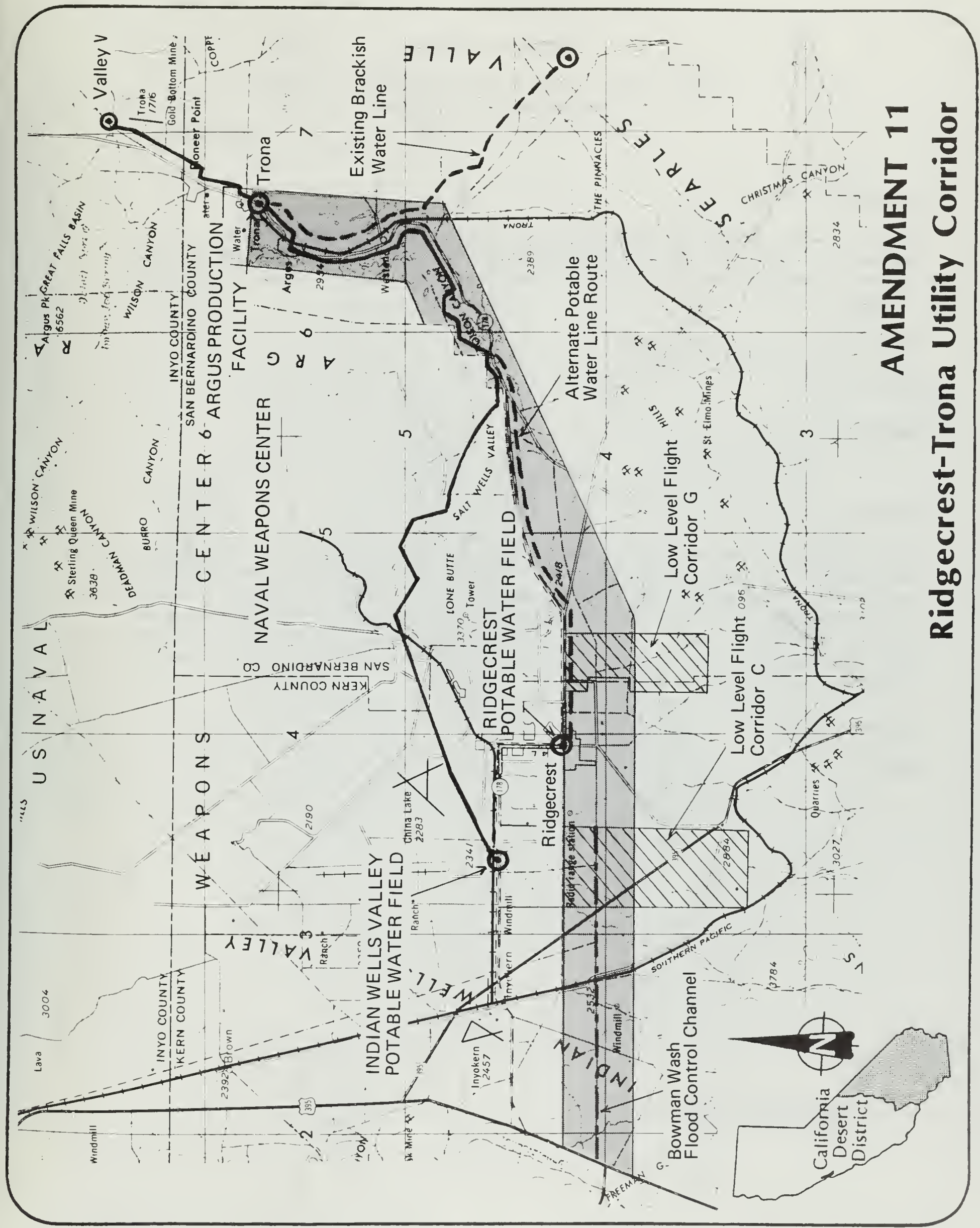


CHANGE VEHICLE ACCESS FROM LIMITED TO CLOSED

IN SAN SEBASTIAN MARSH

\section{Proposed Amendment}

Change Vehicle access designation from "limited to approved routes" to "closed" in a portion of the San Sebastian Marsh ACEC, as proposed in the recently completed ACEC plan. This action would include closure to vehicle camping .

\section{Other Alternatives Considered}

No Action.

\section{$\underline{\text { Decision }}$}

Accept Proposed Amendment.

\section{Rationale}

This change was recommended by the recently completed San Sebastian Marsh ACEC management plan for several reasons. Current vehicle access limitations are not effective in preventing vehicle impacts on sensitive habitats. Habitat for desert pupfish, flat-tailed horned lizard, Colorado Desert fringe-toed lizard, rare plants and possibly the San Felipe leopard frog would benefit from the closure. Important cultural resources would also be protected through the closure.

\section{Implementation}

None.
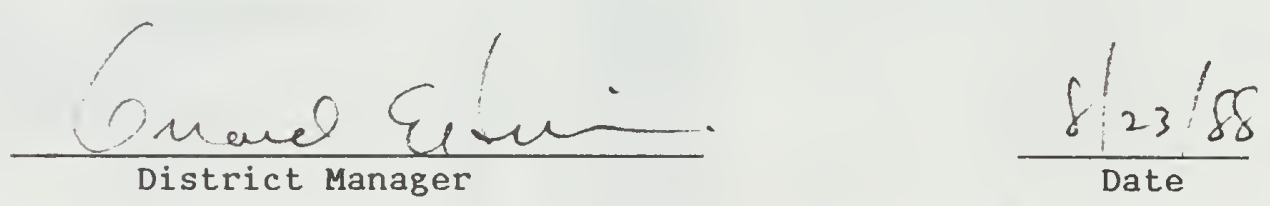


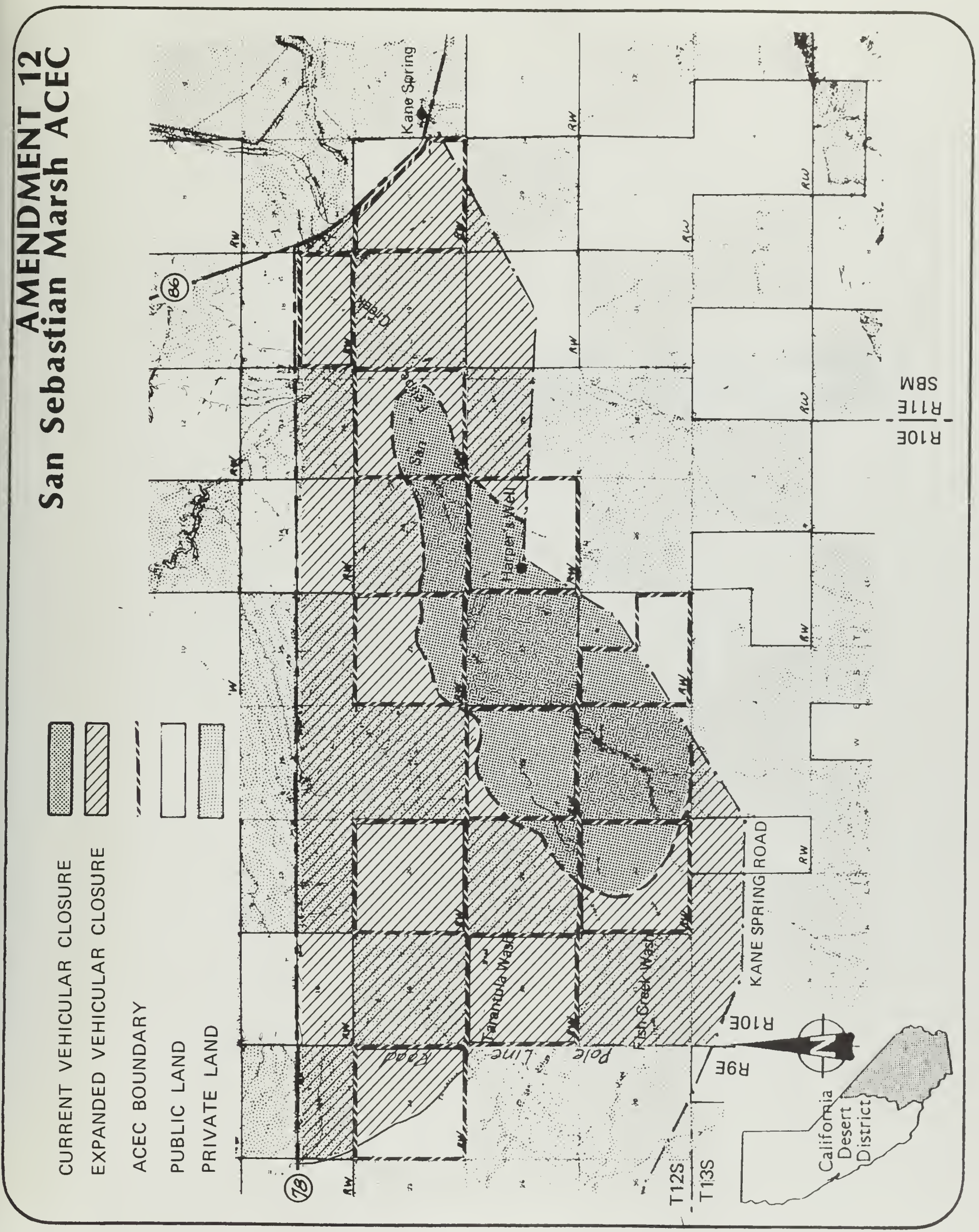





\section{COMMENTS and RESPONSES}



The BLM received a total of 39 letters addressing the proposed amendments during the public comment period. All letters received were reviewed. Those letters that had substantive comments (questions or issues that had a direct bearing on a proposed amendment) were given a response. Table 1 lists each conment letter in order of receipt and identifies its reference number. Within a comment letter substantive remarks are identified. The responses which accompany each letter are keyed to the appropriate comment by the reference number that appears on the comment letter.

All conment letters have been reprinted verbatim and substantive comments addressed. Letters that did not address substantive issues but presented an opinion are acknowledge by their inclusion. In one instance, a comment letter was acknowledged by a letter and this response was placed in Appendix A. 
Table 1

COMMENT LETTERS

Letter

Number

1

2

3

4

5

6

7

$7 \mathrm{~A}$

8

9

10

11

12

13

$13 \mathrm{~A}$

14

15

16

17

18

19

20
Source of Letter

Mary Ann Henry

Arthur Unger, Kern-Kaweah Chapter, Sierra Club

Peter Burk, Citizens for Mojave National Park

John D. Wehausen, Ph.D.

Jay B Wilson, California Wool Growers Association

Thomas J. McGill, Naval Weapons Center

Kenneth H. Taylor

Kenneth H. Taylor

Captain M.R. Boston, Naval Air Facility, El Centro

Randall L. Abbott, Planning \& Development Services, Bakersfield

Pamela MacKay

Ted Rado

D'Arcy P. Bannister, Bureau of Mines

Mary Ann Henty

Mar'y Ann Hency

Richard C. Schwabe

Richard W. May, Desert Research International

Fred L. Austin, Crown Mining Corporation

Mr. \& Mr's. Robert Meade

Judith L. Hol.lins

Chatmaine Parkes

George E. Moncsko, Desert Tortoise Preserve Conmittee, Inc. 
Peter Hillier, M.D.

Michael Hillier

Joe Evans

David R. Hembree, Queenstake Resources (USA) Inc.

John R. Swanson

Betty Forgey

Glenn R. Stewart, Ph.D., The Desert Tortoise Council

Betty H. Matyas

C. Panlaqui

J.W. Teeter, United States Fish and Wildife Service

Ron Schiller, High Desert Multiple-Use Coalition

Patricia Schifferle, The Wilderness Society

James R. Geary, High Desert District

Donald F'alk, Desert Survivor's

Richard Spotts, Defenders of Wildife

Kathryn Gualtieri, Office Historic Preservation, California

Robert D. Johnstone, Edwards Air Force Base

Gordon F. Snow, The Resources Agency of California

Pete Bontadelli, California Dept of Fish and Game 
California Desert District

Bureau of Iand Ianagement

ATIN: Plan imendments

1695 spruce st.

Riversice, Calif. 92507

Dear Sir:

I received the "Proposed 1987 Plan Amendments"- A document Oct 10.

Thank you for accepting the Short Canyon ACEC proposal I applied for on March 12, 1987. (pg. j-1)

The language of my aplication ias freely quoted in the document. $(s-1,2-3)$.

- My apolication listed four enclosures including, "A Check list of Plants of Short ranyon, 1970-1983 by Mary Ann Henry; and "Additions to the Checklist, 1984-1986", by Mary Ann Henry. This inventory-checklist has been published and distributed to interested people.

It appears there could be a grave error on page $3-4$ of the BLN document.:

"an inventory of the canyon conducted by the California Native Plant Society identified 292 species from 55 plant families".

The staistics quoted were on my application and in my Checklist. It is "strange" the CNPS came up with identical numbers of species as I did. CNF has never been associated with my work in short Canyon.

If the BLM preparer took my list and credited the CliPS, it could have legal implication and is an ethical one. If this act was committed, it tarnishes BLI image.

The BLI preparer used the ONPS name for an inventory in the document. Did the preparer obtain permission from CNPS to do so? ihat was the date of the permission? Who gave it? who did the field work to come up with exactly 292 species in 55 olant families? Has the List been published under CNPS' name? May I please have a copy of the CNPS plant inventory of Short Canyon which credits CNPS?

If an error has truly been made in the "Proposed 1987 Plan Amendments"document, would you please take steps publicly to correct the error-Now.

Thank you,

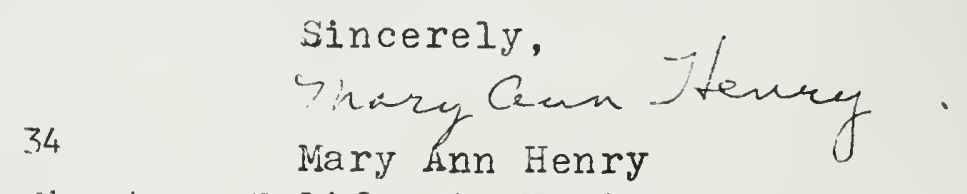

cc. Nary DeDecker, Bristlecone uhapter, California Native Plant Society 
Response to Mar'y Ann Henr'y

Response 1-1

Thank you for the correction. BLM recognizes that Mary Ann Henry and not CNPS was responsible for providing the inventory and the 292 identified species data for the Short Canyon ACEC proposal. 


\section{SIERRA CLUB KeRN-KAwEAн CHAPTER

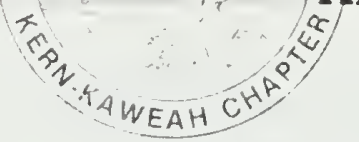

P.0. Box 3357

Bakersfield, CA 93385

October 19, 1987

California Desert District

BLM

1695 Spruce Street

Riverside, CA

Dear Sirs:

We are writing in support of Amendment Number 2, Area of Critical

Environmental Concern. We would like to have the entire drainage of Short Canyon, Kern County, designated as an ACEC.

Short Canyon is north of Indian Wells Canyon and east of Brady's on the east side of the southern Sierra Nevada. There are many resources in this canyon:

1. Botanical - 292 plant species in 55 plant families (Mary Ann Henry of Ridgecrest, CA has published a study done over a 12 year time period)

2. Riparian area - there is an all year stream and several springs

3. This area is ideal for non-consumptive recreation and non-vehicular recreation

4. Wildlife is plentiful, such as songbirds, upland game birds, amphibians, and mammals, including mule deer

5. This is a peaceful and quiet canyon unlike others with ORV useage

Intensive cattle grazing is having a deleterious effect on the plants and on the riparian areas. Designation as an ACEC will protect this valuable canyon for future generations.

Thank you,

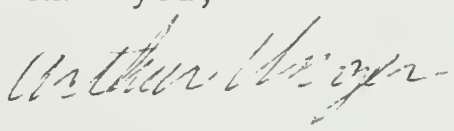

Arthur Unger

Conservation Chair 


\section{CITIZENS FOR MOJAVE NATIONAL PARK}

\section{P. O. BOX 106 BARSTOW, CA. 92311}

California Desert District

Bureau of Land Mangement

3

Attn: Plan Amendment

1695 Spruce St

Riverside, California 92507

Dear Gerry Hillier;

28 October 1987

Again, we are disappointed in the plan amendment process. There is nothing in the plan amendments to improve BLM management of the East Mojave National Scenic Area (EMNSA). The Desert Plan continues to decline.

The one plan amendment that would have improved EMNSA management (eliminating grazing in FMNSA west of Keltaker Road) was re jected.

We recommend rejecting plan amendment $* 10$. The Piute Valley Allotment should be reduced to exclude all grazing inside EMNSA. The damage that welfare grazing does should not be allowed at all in EMNSA. The Fort Piute Wilderness (WSA 271) should not have any grazing in it and the waters from Piute Creek, one of the few perennial desert streams should not the used for welfare grazing. Joe Fvans has been receiving BLM welfare for 12 years and that is ton much. We taxpayers are tired of paying welfare to Joe Evans and his kind. $98 \%$ of our nation's beef comes from private land. It should be 100\%.

Because of bighorn sheep and tortoise habitat, all grazing should be eliminated in EMNSA. The Piute Valley allotment portion that is in EMNSA should be terminated when the lease expires in 1989.

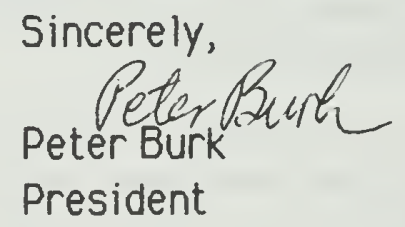

Hilkir

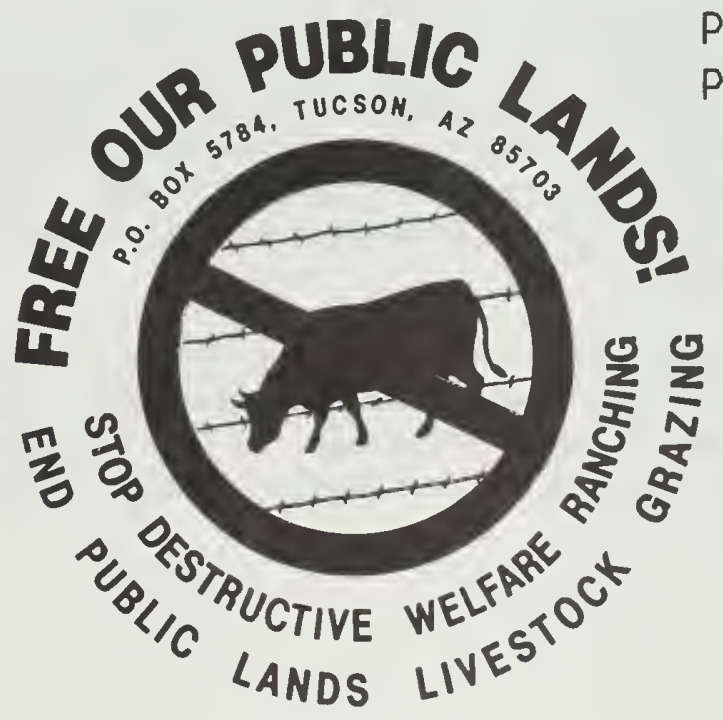

needles 


\section{$87 E A-004$}

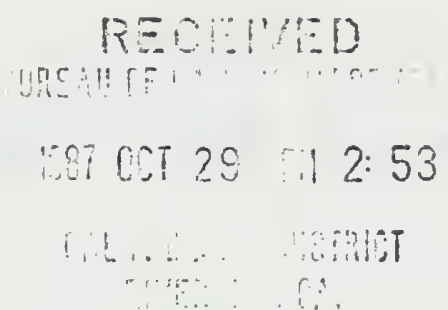

1417 Bear Creek Bishop, CA 93514

26 October 1987

Gerald E. Hillier, District Manager

California Desert District

Bureau of Land Management.

1695 Spruce St.

Riverside, CA 92507

Dear Mr. Hillier:

I am writing to comment on your decision not to accept Amendment $87-P-17$ to the California Desert Plan. This amendment would have experimentally eliminated livestock grazing from the Old Woman Mountains for at least five years. My purpose here is to explain (1) the importance of that proposed amendment, and (2) why your reason for deferring that amendment ("studies are still underway") is inappropriate.

(1) Cattle diseases are now well documented in the native sheep in the Old Woman Mountains. Between 1984 and 1986,16 blood samples were collected. Of these, $19 \%$ showed recent exposure to 4-1 parainfluenza-3 (FI-3), 33\% to bluetongue (BT), and si\% to epizootic hemorrhagic disease (EHD). An additional 5 samples were obtained this year, for which data are not yet available. Clearly, the sheep have a high exposure to cattle diseases. There is no need for further study to document this.

(2) These diseases are well documented elsewhere to be associated with clinical disease states in juvenile mountarn sheep leading to higher than expected mortality le.g. the Santa Rosa Mountains). Such mortality was well documented in the old Woman Mountains isee the report I authored with M. C. Hansen last year, of which your office recelved a copy).

(3) The 0ld Woman Mountains exhibit a low population density, especially for such a resource rich range. This density is approximately one-third that of the neighboring Marble Mountains -- a resource poor range in comparison. Ongoing research along these lines will only further document this comparatively low density in the Old Woman Mountasns. It is no reason to put off a decision on Ammendment $37-\mathrm{P}-17$.

(4) All existing information points to the highly probable hypothesis that cattle are the overwinter reservoirs for BT and EHD. Since there is no reliable way to vaccinate cattle against these diseases, the only way to adequately understand their role as disease reservoirs is to remove

4-3 them entirely from the range for a number of years and continue obtaining blood samples from the sheep, while monitoring their demooraphy. This concept is well spelled out in the enclosed reprint of an article I published on the Santa Rosa Mountains with others this year, and is exactly what Ammendmerit 8 7-F-17 proposes.

(5) The current cattle grazing in the old Woman Mountains occurred as the result of 1981 Amendment 81-21 to the California Desert Plan, which originally proposed no grazing south of I-40. That Amendment included the following stipulation: "At the end of five years (1987), there will be a full reanalysis of the tighorn populations and range conditions. If grazing is shown to negatively 
impact bighorn sheep population, elimination or reduction of cattle range will be considered." Current information suggests that the impacts of cattle in the Old Woman Mountains on the bighorn are substantial through the disease organisms they carry. By the above stipulation in Ammendment 81-21, the logical result would be the elimination of cattle grazing this year. Ammendment 37-P-17, proposed by the Department of Fish and Game, takes a more conservative approach. It suggests removing cattle for only as long as it will take to evaluate the impacts they have been having of the sheep. Ferhaps we will find no charge; but without doing such an exferiment, you will be forever making management decisions relative to this question on the basis of inadequate information. I urge that you seriously reconsider the decision on Ammendment $17-F-17$, that you can better understand the impacts of BLM's grazing program in the desert. To defer this decision on the grounds that studies are underway is to simply avoid this important issue. I look forward to your response on this question.

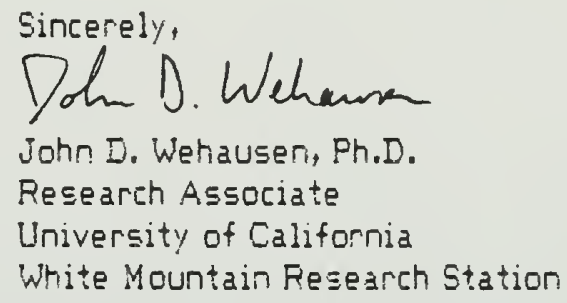


Response to John D. Wehausen, Ph.D.

Response to $4-1,2,3$

See letter from District Manager, Appendix A. 


\title{
CALIFORNIA WOOL GROWERS ASSOCIATION
}

\author{
PE? $\because \cdots$ \\ 1977 12 A 1:0E \\ H. . $\therefore$ BHT \\ [?.'
}

November 6, 1987

5

Gerald E. Hillier

District Manager

California Desert District

Bureau of Land Management

1695 Spruce Street

Riverside, CA 95207

Dear Mr. Hillier:

The California Wool Growers Association, which represents the sheep producers throughout the state of California, would like to comment on the proposed 1987 plan amendments to the California Desert Plan.

The wool Growers have been supportive of the multiple use management of public lands. Your report has carefully taken into consideration all concerned parties. We would like to continue to support multiple use planning and support the amendment changes which have been proposed.

Keep up the good work.

Sincerely,

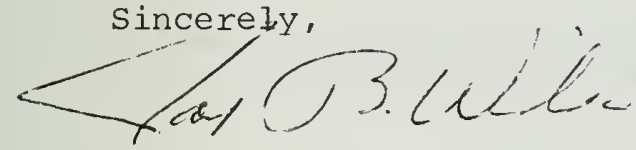

Jay B. Wilson

Executive Vice President

$1 \mathrm{ks}$

CC: Frank Munoz

Don Torell Ukiah, California
Michele C. Howard, Executive Vice President Sacramento, California 
$87 E A-006$

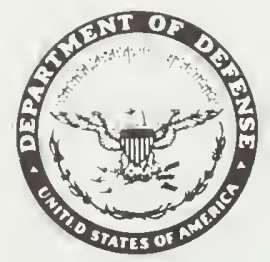

DEPARTMENT OF THE NAVY

NAVAL WEAPRNS GENTERT:" I

CHINA LAKE CALIF RE רIח5: !ी ?"

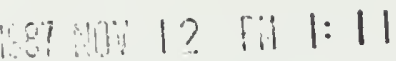

4100

Ser $2662 / 13972$

Mr. Gerald E. Hillier, District Manager

California Desert District

Bureau of Land Management

1695 Spruce Street

Riverside, CA 92507

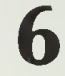

Dear Mr. Hillier:

The Naval Weapons Center (NAVWPNCEN) would like to take this opportunity to comment on the Environmental Assessment for the Proposed 1987 Amendments to the California Desert Conservation Area Plan.

Our concerns pertain to Amendment 11, which would establish a new utility corridor from Corridor A at Inyokern to Kerr McGee facilities near Trona.

The Environmerital Consequences (Chapter 4) section of the Environmental Assessment discusses the potential for the installation of high voltage powerlines within the new corridor. These structures would traverse the B Range, C Range and G Range low flight corridors used by NAVWPNCEN.

The Center is concerned that above ground structures such as powerlines may preclude the use of these test ranges for certain types of testing activities. The types of tests conducted on these ranges cannot be duplicated at any other military facility. The mission of the NAVWPNCEN could be severely impacted by the loss of these ranges.

If you have any questions or need additional information the point of contact is Mr. Tom Campbe11. He can be reached by telephone a (619) 939-3411, extension 550 .
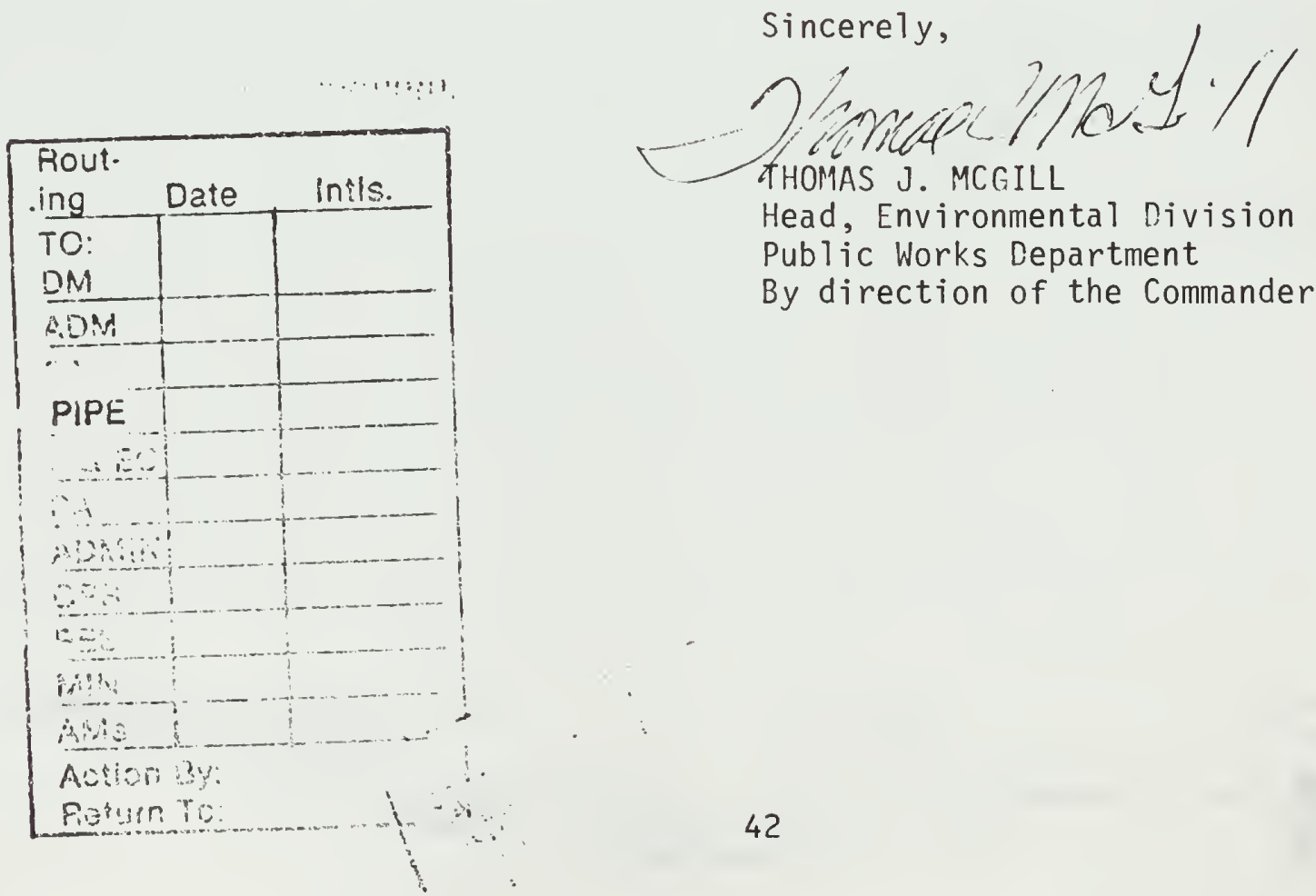
Response to Naval Weapons Center, Department of Navy

\section{Response $6-1$}

Mitigation Measure 11-1 (page 4-18, EA) reconmends limiting electrical transmission towers and any other facilities to 125 feet in height within the Naval Weapons Center's $\mathrm{C}$ and G Low Flight corridors. This measure will become a condition of approval of any above-ground structures that are authorized within the $C$ and $G$ corridors. 
87 LA-007

Tuveat - r 5,-887

Califurria D sait District

u au of jencianzinent

Attn: In Airen ments

I just fininlied roacing y coy 1.37 Tan Anendments

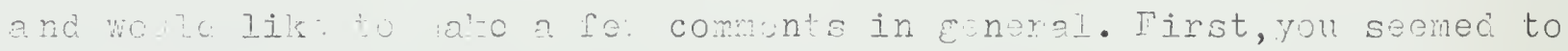

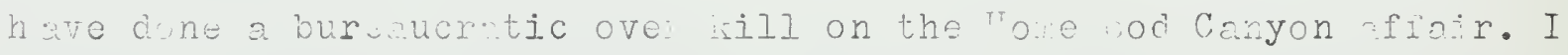
shudoer to thin's of the fodinal funds spent for the pr an porhee, which as I sec it is the wril wrtar ill over again. a survey of

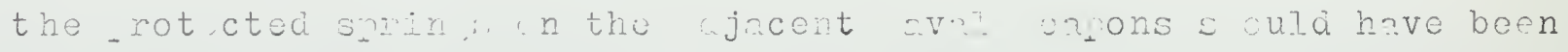
done first. Iise the nail arter sho inj $u$ in risy othor arous, the Rrown towhe could also, bit ho knows?

liy saconc comment is? at rabid siex a club environ-

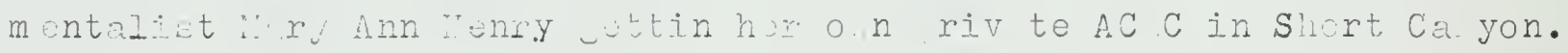

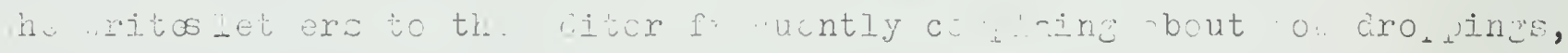

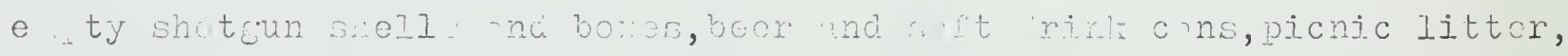

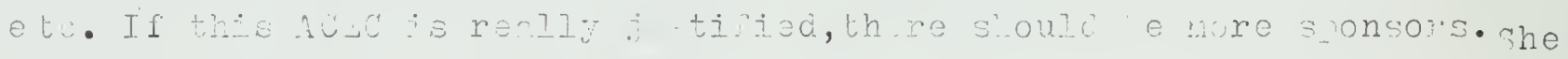

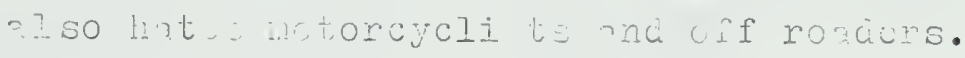

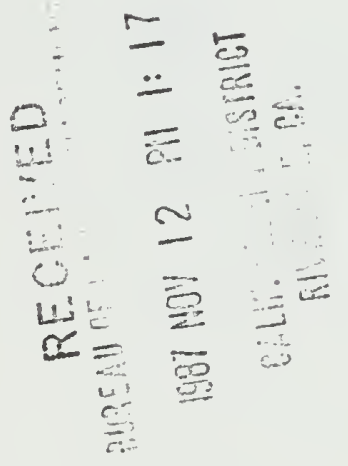

44 
California liesert District

Bureau of liand Hanarement

Attn: Llan Amendments

1695 spruce st.

Riverside, CA 9250 ?

I have already submitted onecomment on my letter

dated November 5, but since then I have come into adcitional information

that roinpts this letier. My original letter was concerning the short

Canyon ACHC as being the vrivate preserve of liary Ann Henry,one of our

I ocal and highly vorbal Sierra Club members. R cently I found out that

the manager of the LM Ridgecrest office, atricia Viaclean is also a Sierra Club meinber.

1 would think that this would pose a definete

"conflict of interest"for Ms.Mclean. The Sierra Club has almost a perfect record of opposing all mining, cattle grazing, timbering and develoment. They re recently sucessful in closing down one of our local places the employmont, they lumber nill north of Inyokern at Puarsonville. All the above runs cortrary to the concept of"multiple I nd use" as acivocates by the 3LM. :OW can Ms. Maclean advocate the stand taken by her employer and her club at the same time? I think the sime shoulc hold true for any government employee entrusted to manage public lands wilich would include forestry officials. Perhaps en Senator Cranston is a member and is advocating changing the 1976 1 aw he is sworn to uphold.

$$
\begin{aligned}
& \text { - Sincerely } \\
& \text { Kenneth H.Taylor } \\
& 216 \text { ir.Robertson Rd. } \\
& \text { Ridgecrst, CA } 93555
\end{aligned}
$$


DEPARTMENT OF THE NAVY

NAVAL AIR FACILITY

EL CENTRO, CALIFORNIA 92243

\section{IN REPLY REFER TO: \\ 5090 \\ Ser $32 / 283$ \\ NOV 131987}

California Desert District

Bureau of Land Management

Attn: Plan Amendments

1695 Spruce Street

Riverside, CA 92507

Subj: PROPOSED 1987 AMENDMENTS TO THE CALIFORNIA DESERT CONSERVATION AREA PLAN

\section{Gentlemen:}

We have examined amendments one, four, eight, and twelve with respect to their impact on Navy operations. Maximum usage consistent with public safety was the criterion used.

The preferred amendment, in each case, is acceptable to the Navy.

Thank you for the opportunity to comment on these plan amendments. Point of contact at NAF El Centro is Mr. Roger Hillhouse at (619) 339-2201.

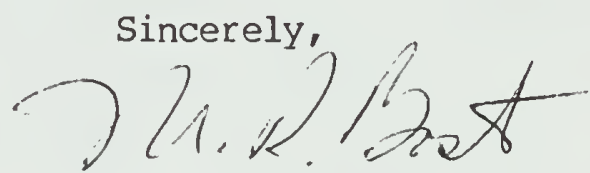

M. R. BOSTON

Captain, U. S. Navy

Commanding Officer

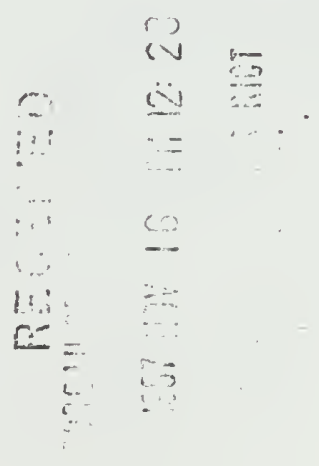




\section{DEPARTMENT OF PLANNING AND DEVELOPMENT SERVICES}

RANDALL L. ABBOTT

DIRECTOR

STEVEN G. LADD

Assistant Director

November 10, 1987
Mailing: 1415 Truxtun Avenue Bakersfield, CA 93301 Location: 1356 Norris Road Bakersfield, CA 93308

(805) 861-2615

FILE: Agency US Govt-BLM

California Desert District

Bureau of Land Management

Attention Plan Amendments

1695 Spruce Street

Riverside, CA 92507

Re: Environmental Review: Proposed 1987 Plan Amendments to California Desert Plan

Ladies and Gentlemen:

Thank you for the opportunity to review the above-noted project. We note that the second proposed amendment will designate the entire drainage of Short Canyon, Kern County, as an ACEC (Area of Critical Environmental Concern). This would not appear to affect vegetation, wildlife, or grazing because of Walker Pass AMP. The amendment would have little or no effect on geologic, energy, or minerals characteristic of the area. Recreation will be enhanced.

Amendment 6 will change 2,164 acres of unclassified land adjacent to Red Rock Canyon State Park to Class L (Limited Use Area). Designation of this land as Class $L$ would provide management of sensitive cultural resources that are consistent with that afforded resources in the surrounding area. This amendment would also provide for recreation management needs and require a plan of operation for any surface disturbance which would result from mineral development. This would not appear to be a significant impact on the development of saleable or locatable mineral resources.

Neither the Red Rock Canyon "L" Class Amendment or the Short Canyon ACEC appear to have any effects on private land in the area. We have no further comments at this time.

Very truly yours,

RANDALL L. ABBOTT, Director

Planning and Development Services Junior Planner

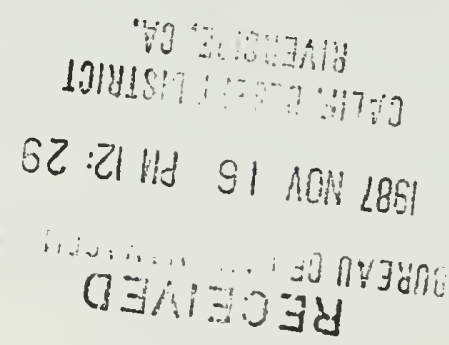

47 


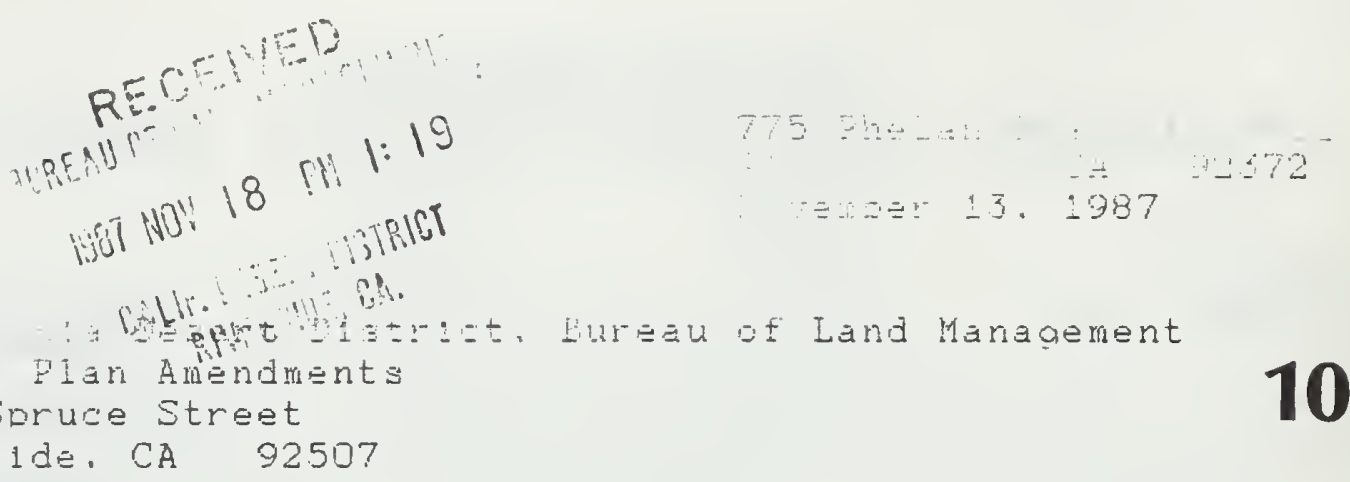

A. . plar Anendments

1695 Soruce Street

Riverside. CA $9250 ?$

Dear Sirs:

I am writina regarding the Short Canyon ACEC CPIan Amendment \#2) proposed by MaryAnn Henry. I visited Short Caryon in October of 1980 with iny students from Victor Valley College in Victorvilie, California. We found the canyon to be a unique and fascinating area to study natural history. Many species of desert shrubs and wildflowers were present, some of which we found nowhere else. I understand from Ms. Henry's data that the canyon has at least 295 specles of plants, including a category 2 candidate for endangered status with the U. S. Fish and Wildlife Service. Fhacelia nashiana. Wildife species were also evident on our visit.

Also evident was the destructive influence of grazing animals. We found many areas where soli was eroding into the stream and native plants on the streambanks were overgrazed. As you know, trampling by heavy animals also impacts the vegetation severely. Ilvestock wastes also pollute the water. Unfortunately, these occurences have disruptive effects on wildife species since many desert species directly depend on the water and vegetation of riparian areas. This destruction of habitat will continue and worsen unless $1 \mathrm{mmediate}$ steps are taken.

These are my recommendations:

1) Use the pipeline proposed in the Allotment Management Plan to divert I lvestock away from the stream.

2) Do not construct a fence since it would also limit the mobility of larger wlldife, especially mule deer.

3) Please do NOT allow vehlcular transportation for recreation in the canyon. Effects of vehicles are similar to (and worse than) livestock grazing. Compaction and disturbance of soll lead to increased erosion. Which leads to logs of plant cover and silting of stream. The net effect is destruction of habitat. AND loss of a beautiful. quiet, peaceful place (one of the few left). 4) Please include the falls of Short Canyon in the ACEC. Thankyou very much!

Sincerely yours,

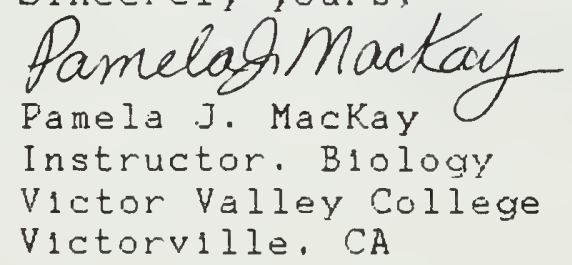




\section{Response 10-1}

Curent plans for protection of the area within the proposed ACEC are underway. Livestock will not have access to the aquatic and riparian habitats in the Short Canyon basin or watershed. This will be accomplished through livestock fencing which will restrict cattle movements within the ACEC. The fence is almost complete and has been designed to allow for wildlife movements, including mule deer movements both over and under the barbed wire strands. Steep terrain, not negotiable by cattle, has been left unfenced, and this will further allow for deer and other wildlife movements into and out of the ACEC. The purpose of the proposed pipeline is to provide a livestock water trough(s) east of the ACEC and livestock fence. Water for these facilities will originate from the old concrete dam immediately above the small waterfall within the ACEC. 
2430 Fair Daks Blvd.. Apt. 179 Sacramento, California $95825:-$ November 9,1987

Mr. Lerald E. Hillier

[1 i s t r cit lanager

Bultau of Land Management

Calitornia besert ristrict office

logs Srruce Street

Fiverside, Californis 92507

lear Mr. Hillier:

Thank you for the officrunity to provide coinments on the 1987 i) Esert. Plan amendments. My specific comments for each amendment tol low.

(1) l strongly sufport the bureau's decision to designate an aditional Area of Critical Envirommental Concern in the West Mesa. A recent status report on the flat-tailed horned lizard underscores the importance of establishing reserves for this species. Bureau-initiated studies also indicate tiat extant populations are declining in other areas, necessitating increased protection of remaining areas where the species is comparatively abundant.

(2) 1 support acceptence of this amendment. Livestock grazing. paticular ly when concentrated in canyon bottoms and ripgran cor idors, can result in heavy damage to vegetation. A carefully developed management plan for the area also warrants high priority.

(3) i urge modification of the rroposed ACEC boundary expansion to irciude all areas within designated critical habitat of the lnyo brown towhee cexclusive of those within the China l.ake Naval Weopons Center). The limited geographic range and low population numbers of this species warrant a high louel of rotective management.

(4) 1 have na comment on this amendment.

(5) I recominend acceptance of Alternative A. The rationale for proposing Alternative B in the text on page $2-4$ of the draft envirommental assessment suggests that current grazing and mining operations preclude the opportunity for meaningful managenont of wildife resources in this area, when this is not the case. Grazing allotment management plans, as with al l otier plans rieveloped for specific resource management in the C[CA, can be revised based on additional information. l would expect that AUM allocations, for example, could be adjusted to ensure adequate forage for desert bighorn sheep in the Morti Coso Range. if any Habitat Management Plan developed alls for establishment and naintenance of a certain number of animals here.

(1) I recommend acceptance of this amendment. I've visited the Fiedrock: Canyon area regularly since 1964, and strongly 
believe that it is in the best public interest to retain Federal ownership and management of these lands because of their scenic and recreational values. The subject Bureauadministered lands could also have palerintological values as we 11 .

(7) I recommend rejection of this amendment. In spite oi the intentions of the proponents, retention under Federal management is necessary given area resource sensitivity.

(8) I have no comment on this amendment.

(9) I have no comment on this amendment.

(10) l strongly urge rejection of this amendment. It seems abvious that major conflicts will result between livestock grazing and wildife and vegetation resource protection it livestock perennial forage utilization is authorized. The amount of resource danage wruld also far surpass any benefits to the public derived by increasing the livestock production level over this al lotment area. Any related livestock "inprovements", such as pens, fences. etc. may also conflict with wilderness area protection. should the Fort Piute Wilderness Study Area receive such status by Congress.

(11) l have no comment on this amendment.

(12) I strongly urge support of this amendment. Expansion ot an existing vehicle closure zone is necessary it the present level is insufficent to ensure appropriate levels of protection of the federally-listed desert pupfish. candidate-for-listing San Sebastian leopard frog and t lattailed horned lizard, and other sensitive resources.

Rejected Amendment $87-P-2$.

l believe that. given the importance of the Fremont Valley towards long-term perpetuation of the desert tortoise. and the inability of the Bureau to eftectively enforce vehicle route designations over the area (resulting in widespread deterioration of habitat), this proposed amendment clearly should have been accepted. l've witnessed this widespread Environmental degradation first-hand over the preceeding 23 years, particularly in the last 15 years. with obvious declines in desert tortoise abundance. From a management standpoint, given the extreme fragility of the area and speculative nature of instituting effective habitat restoration from off-road vehicle-induced impacts to Mojave Desert soils and vegetation, it seems obvious that increasingly stringent protection is required. Deterring the issue pending development of an ACEC management plan allows for continued environmental degradation. A more etfective means of ensuring resource protection would be to increase the size of the existing ACEC to include all sensitive areas, and then adjust the ACEC boundary after development of a carefully developed and detailed management plan. This strategy would also expedite the timing for ACEC management plan completion. The subject plan is already several years behind schedule, with no guarantee that 
p plan completion will meet the "amended" schedule for completion by no later than Dotober 1988. Needless to say, this is the second consecutive year that the Bureau has deferred any decision in tris matter.

\section{Rejected Amendment $87-\mathrm{P}-15$}

The prior Desert Plan amendment to allow expansion from a $100-$ to a 300-fopt-wide camping zone along vehicular routes in the CDCA may result in the avoidable loss of many desert tortoises and associated degradation of habitat. The proposed amendment would selectively restrict this camping width in areas of high desert tortoise population density. Using the route designation process to defer any decision blatently ignores the fact that this process has already been completed for a large portion of the

11-2 California Desert without any restrictions on camping zones for tortoise protection. Given the fact that no reasonable alternative courses of action are viable, the amendment should have been accepted by the Bureau.

Please provide me with a copy of your final environmental assessment. I would also like to be retained on your mailing list for other documents subject to public review and comment. lncidentally. I've heard that the next draft Afton Canyon ACEC Management Plan will be available for public comment shortly, and request a copy of this for review when available.

Sincerely,

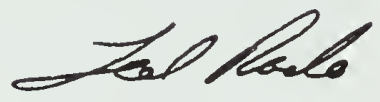

Ted Rado

Wildlife Biologist

boc 
Respond to Ted Rado

Response 11-1

The BLM agrees that increased protection of tortoise habitat in Fremont valley and the Rand Mountains is necessary to halt and reverse the significant declines in both habitat quality and the desert tortoise population.

The California Desert District formed a team of qualified individuals who regularly met over a 12 month period for the purpose of developing a series of recommendations for managing desert tortoises and their habitat. The team's recommendations are being reviewed and will be finalized soon. Also, the Ridgecrest Resource Area office is beginning the process for development of a comprehensive land use and habitat management plan for the entire Fremont Valley and Rand Mountains. The purpose of this plan will be to identify what actions are needed to maintain viable populations of desert tortoises as well as developing actions needed for managing multiple land uses. The final plan for this area is expected to be completed in October of 1989. Extensive public involvement and public review of a draft plan is also planned.

The BLM with the cooperation of District 37 of the American Motorcycle Association has restricted competitive of f-road vehicle racing in Fremont Valley and the Rand Mountains. Until a final management plan is developed, there will be no race starts, pitting or finishes in the area, and no races will be allowed from March 1 to June 30. The only races allowed will be on approved routes and outside the closure dates. We believe that full public involvement will provide for development of a more appropriate management plan for the area and a more successful implementation of the actions that are approved in the final.

Response 11-2

The concept of restricting vehicle use and camping within crucial desert tortoise habitat is being discussed in the District Tortoise Work Group. A comprehensive plan for managing desert tortoise habitat is being finalized and will address necessary actions related to the potential for increased impact to desert tortoises within the 300 foot camping/vehicle parking zone adjacent to open vehicle routes. 


\title{
United States Department of the Interior
}

\author{
BUREAU OF MINES \\ WESTERN FIELD OPERATIONS CENTER \\ EAST 360 3RD AVENUE \\ SPOKANE, WASHINGTON 99202
}

November 18,1987

Memorandum

To: Cal ifornia Desert District, Bureau of Land Management, Riverside, Cali fornia

ATTN: Plan Amendments

From: $\quad$ Supervisor, Mineral Issues Involvement Section, Branch of Engineering and Economic Analysis

Subject: Enviromental Assessment of the Proposed $1987 \mathrm{Plan}$ Amendments to the California Desert Plan

Our canments on the subject amendments are directed towards the proposed designation of Areas of Critical Environmental Concern (ACEC) for wildlife, botanical, and cultural resource values in the West Mesa area of Imperial County, and the designation of the entire drainage of Short Canyon, Kern County.

- ACEC status may allow multiple use, but mineral exploration or development would likely be subject to severe restrictions not found on open lands. On page 4-2, the proposed 1987 plan incorrectly states that creating the ACEC "would have no effect since the ACEC designation does not, in and of itself, withdraw the lands involved from operation of the mineral leasing, location 12-1 and saleable laws." However, on page 4-3 it is stated, "Any added layer of protection may make the development of mining claims in existence prior to 1976 (if any exist) more difficult if conflicts arise with the resource value the ACEC is designed to protect." Also, comments on page 4-5 note how an ACEC "may conflict with mining activities" and may pose "some constraints" on how mining development may proceed. These are more correct, and the statement on - page 4-2 should be changed.

We suggest that more consideration be given to the possible effects (either beneficial or adverse) to the mineral natural resource utilization prior to designating ACECS. Thank you for the opportunity to comment.

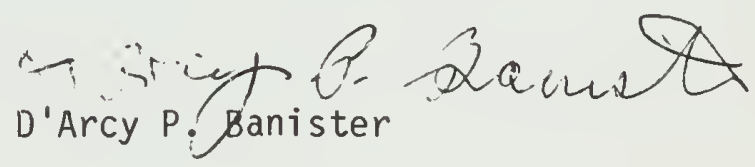


Response to Western Field Operations Center, Bureau of Mines

Response 12-1

The statement on 4-2 is true insofar as the withdrawal issue is concerned. However, it is also true that there is the potential for an effect on mineral development by requiring through the ACEC plan more protection measures. The level of protection established may cause an operation to be unncessary or undue, because this threshold is to be maintained in the ACEC. 
329 Perdew

Ridgecrest, CA

Nov. 22,1987

California Tesert District, Bureau of Land Management ATTN: Plan imendments

1695 Spruce Street

Riverside, Calif. 92507

Dear Pian Amendments:

Thank you for acceptine alternative $A$ for the proposed Plan Amendment /2, to designate the entire drainage, including the falls of Short Canyon, Kern County as an irea of Critical Environmental Concern.

i... I wish to support the Short Canyon ACEC Plan Amendment $\# 2$.
The ACEC was proposed as a botannical resource. On page $5-4$ the document proposes the canyon to be used for "recreation". But what is "recreation"? In BIM parlance for many years this word means 13-1 ORVs--period. ORVs are not compatible with a short Canyon ACEC. why can't the ACEC be listed for both its botannical resources and for non-consumptive, non-vehicular recreation?

It is true the oniy so-called sensitive plant species reported from Short Canyon is the Phacelia nashiana, a category 2 candidate for endanered status with the U.S. Fish and Wildife Service. The great diversity of plant species ir the canyon is worthy of notice by the BIM. The plant diversity is a feature which attracts formal and informan educational classes from far and near who come to the canyon.

Part of the charm of Short Canyon, I am told by users, is the freedom to walk anywhere and freedom from ORVs.

- I hope the management plan prohibits recreational shooting outside of hunting season as this activity is not compatible with an HCEC 13-2 designation and strikes terror to the hearts of other users. Men a right to bear arms; only the BLM gives them permission to shoot an ACEC outside of hunting season.

It is good the BLM plans to provide water for livestock via a pipeline outside the iSA which could divert the cattle, both legal and trespass cattle, away from the riparian area of the ACEC.

rlease support the creation of the Short Canyon Area of Critical Environmental Concern for botannical resources and recreation.

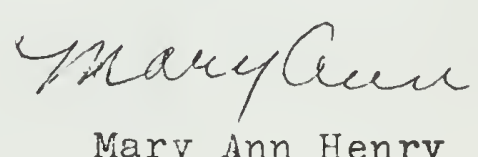

Mary Ann Henry

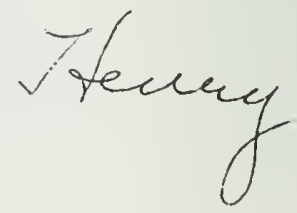


Response to Mary Ann Henry

Response 13-1

The upper portion of Short Canyon has important botanical and recreational values. The value for recreation use involves hiking, sightseeing and day-use. Vehicles will be confined to one designated route of travel which ends at a parking area on the east side of the proposed ACEC.

\section{Response 13-2}

Restriction on hunting and shooting within the ACEC will considered in the management plan. 
(i)

n

ëalifornia Desert District, Bureau of Iand lianagernent ATR: Plan Amendments

1695 spmuce street

porviside, Calif. 92507

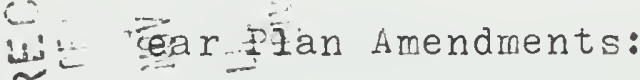

I Wish to support the following Plan Amendments for 19:7:

1. Vest Mesa ACEC, Alternative A.

3. Great Falls 3asin ACEC, ilternative A.

5. Designate six new habitat management area in Mono ard northern Inyo colinties, Alternative "s".

6. Changing the Multiple use Class Jesignation in Red lock Canyon from unclassified to Class L; Alternative A

IQ also, wish to reject rian bmendment 10 , changing grazing cattle allotment to ephemeral-perennial.

11. I accept alternative A of this Amendment

12. I support the closure of San Sebasitna Narsh ACEC to vehicles.

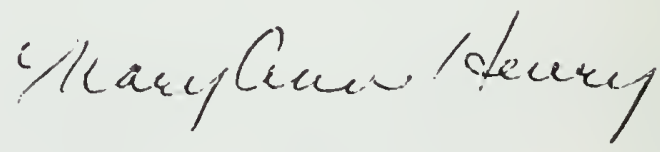

Nary Ann Henry 


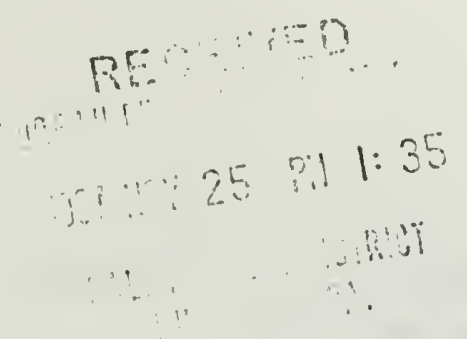

P. O. Box 3707

South Pasadena, CA 91030-6707

November 20, 1987

California Desert District

Bureau of Land Management

Attention: Plan Amendments

1695 Spruce Street

Riverside, CA 92507

I wholeheartedly support designating the entire drainage of Short Canyon, Kern County, north of Walker Pass, including the canyon ridges at higher elevations, as an Area of Critical Environmental Concern as proposed as Amendment Number 2 to the California Desert Plan.

Having visited Short Canyon I can attest to the fact that it contains remarkable botanical diversity which deserves protection. The Phacelia nashiana which grows there is a spectacular flower, a candidate for endangered status with the U. S. Fish and Wildlife Service.

The special nature of this canyon would argue against allowing off-road vehicle use there. It should remain undisturbed by ORVs.

Cattle grazing should be minimized in Short Canyon. Cattle can be particularly hard on an area such as this. I understand that a water pipeline from the riparian area to outside the Owen's Peak Wilderness Study Area Number 158 has been proposed by a recent Allotment Management Plan as a way to divert the cattle from this riparian area of the ACEC and I support this proposal.

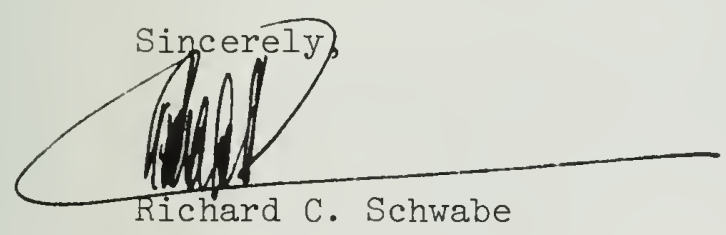




\section{DESERT. RESEARCH INTERNATIONAL}

\section{A MON PROFIT TAX EXEMPT OROANIZATION}

California Desert District

BLM

1695 Spruce St.

Riverside, California 92507

Attn: Plan Amendments

Dear Sir,

I would like to voice my support for Plan Amendment \#2 for designation of the Short Canyon Area as an ACEC. The diversity of flora and fauna, including at least one candidate species for status as Endangered, make it a viable candidate. Based on the my field experience in this area, it would appear that the entire drainage should be included, incorporating the Short Canyon Falls area. I am also concerned about the cattle grazing. Serious consideration should be given to diverting cattle from this area, either through the pipeline proposal or other means (excluding fencing).

Please submit my comments to the upcoming public review.

Sincerely,
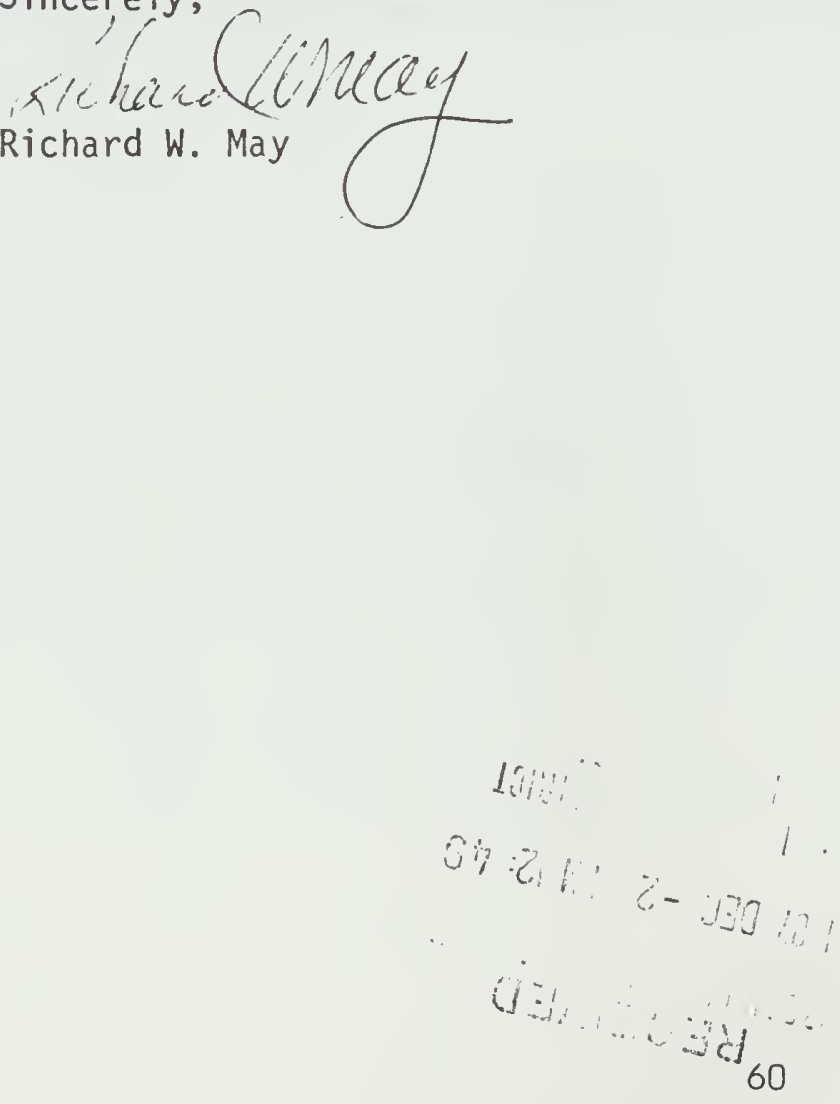
CROWN MINING CORPORATION

110 Newport Center Drive - Suite 200

Newport Beach, CA 92660

December 3, 1987

Bureau of Land Management

California Desert District

1695 Spruce Street

Riverside, CA 92507

Res Rroposed Plan Amendments - California Desert Plan

$\ddot{\sim}$.

.... Gentlemen:

The proposed 1987 Plan Amendment to the California Desert Plan dated

16-1 October, 1987 under Amendment 3, Alternative A proposes, as we understand

.. Lit that the Ruth Mine be included in the A.C.E.C. boundary.

co

As president and principal stockholder of the Crown Mining Corporation, this is to advise you that we are opposed to the inclusion of the Ruth Mine and the eleven mining claims constituting Crown Mining Corporation leased property.

These claims of Crown Mining have been under lease by stockholders of the same three families beginning in 1916. The taxes and assessment work has been paid and accomplished by them up to and including the current year.

During the period 1930 to 1942, the Ruth Mine was the largest operating gold mine in the area, producing 120 tons of ore per day. The mine was ordered closed in 1942 by the War Manpower Mining Act. It has not reopened because of the factors of required start-up capitol, the price of gold and the cost of labor.

Five years ago Crown Mining negotiated an Option of Purchase with Queenstake Resources Limited, a Canadian Corporation, 70\% controlled by U. S. citizens. Since that time major expenditures have been invested to analyze the extent of the ore body by core drilling, assay reports, etc. At the present time, these geologists are on the property to further analyze the area extent and value of the ore body.

16-2 We obvious therefore expect at some future time to mine the ore if permissible under the existing rules and regulations.

Water for domestic purposes is obtained from natural springs and piped to an 1800 gallon tank at the Ruth Mine by pipe over the leased mining claims at the Crown property. Surplus water feeds into a remote pond prepared for wildlife feeding with large trees, bushes, grass and wild mint. A natural sanctuary for birds and wild animals. 
There are two caretakers located on the property providing 24 hour coverage and an owner's residence. No new residences or buildings have been constructed since 1935. Thus there has been no expansion or exploitation of the land.

Amendment 3 as originally planned deleted the Ruth Mine from the A.C.E.C. and it is our understanding your District Advisory Council recommended deleting the Ruth Mine and the Homewood Canyon area from the A.C.E.C. at their last meeting.

If, in the final draft of the plan, the Crown Mining properties including the Ruth Mine are not deleted, we respectfully request an opportunity to personally discuss this matter with your representative. It appears considerable misstatements of fact concerning the Ruth Mine in both the plan(s) and correspondence need to be clarified if any negative action is to be taken.

The B.L.M. has been provided detailed drawings and plans of the Crown Mining properties known as the Ruth Mine by both Queenstake Properties and the Crown Mining Corporation.

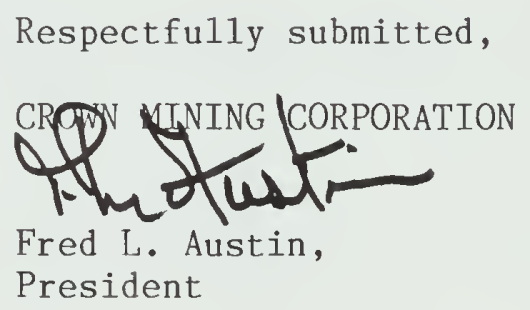

FLA : s 
Response to Crown Mining Corporation

Response $16-1$

Alternative A to proposed Amendment 3 calls for deleting the highly disturbed area at the Ruth Mine from the Great Falls Basin ACEC.

Response 16-2

An ACEC does not change the mining regulations under existing law. In the case of the Ruth Mine, the area of existing disturbance is proposed for deletion from the ACEC for the reasons stated in the Environmental Assessment.

Public lands outside the presently disturbed area will remain inside the ACEC. On thse lands, the ACEC's natural resource values, scenery and wildlife, are to be protected. Wildlife resources include the Inyo brown towhee, a threatened species under the Endangered species Act of both the State and Federal governments. These laws call for mandatory protection of this species and its habitat. 


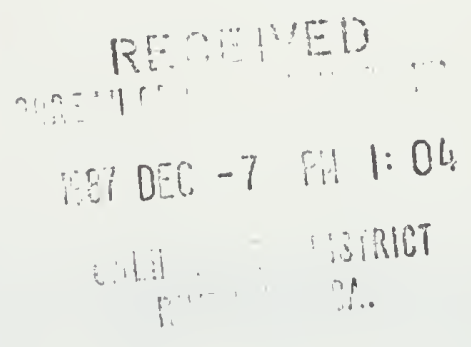

4 Dec 87

From: $\quad$ Mr. \& Mrs. Robert Meade

17

237 North Alford St.

Ridgecrest, CA 93555

To: $\quad$ California Desert District, BLM

1695 Spruce St.

Riverside, CA 92507

ATTN: Plan Amendments

Subject: $\quad$ Support for the proposed Plan Amendment * 2 which would designate the Short Canyon watershed as an Area of Critical Environmental Concern.

For many years we have visited this area to enjoy the relatively readily accessible native plants and wild life. We support the proposed Plan Amendment as vital to the preservation of the varied botanical resources and to the maintance of unspoiled nature of this canyon. We support the planned pipeline to provide water to livestock outside the canyon area but are less sure of the desireability of the cattle fencing.

Thank You

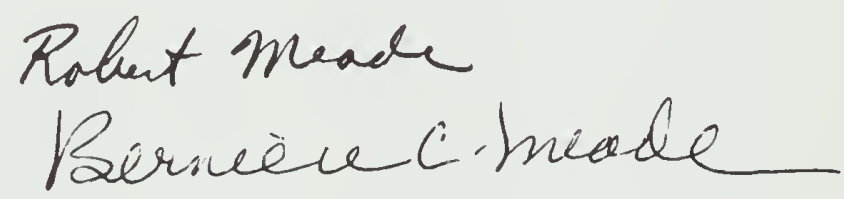


$87-E A-018$

Calif. Desert District

Bureau of hand Management REAPEDS...

Attn. Plan Amendments 1070 DEC -7:1:05

1695 Spruce St.

Riverside CA. 92507

18

Dear Sir or Madam,

$\operatorname{Dec}, 4,1987$

I am writing in support of the short Canyon Area of Critical Environmental Concern (ACEC) (Plan Amendment \#2) proposal.

I teach a Desert Biology class for the Sierra Sands School District every Spring and a Biology class every Fall. (Adult School). Short Canyon is definitely the best place to go to view * study desert wildflowers. It may be the only place within a convenient distance that still has a good display af a variety of wildflowers.

In addition to taking classes there for botanical study, I have on many occasions taken out-of-town visitors or new comers to Short Canyon so they can appreciate the desert's unique habitat, peace and quiet.

Please support the preservation of Short Canyon and the entire drainage (the wash has great wildflowers, too.) as a quiet preserve, free from motor-cycle or offroad traffic, and free from destructive cattle grazing.

$$
\begin{aligned}
& \text { Thank you, Judith 2. Walling } \\
& \text { Judith L. Hollies } \\
& 628 \text { Wildrose } \\
& 65 \text { Ridgecrest, CA } 93555 \\
& \text { ph. } 619-375-7075
\end{aligned}
$$


To the Members of The Bureau of Land Management: 19 I urge you to make the marginal amendment to The boundary at The northeast portion of the ACEC so that Queenstake can continue its Cuondo-Davenport development. I have inherited the Davenport mine from my mother who inherited it from my 8 and mother. (all these years of scraping up money or assess mint work - and now, when it looks as if the mine might pay off Let measure you that I have great respect -and love. For the environment and will always cooperate with the ACEC.

Because we have no water, we have few birds. Just itinerant crows, hards, scorpions, Tarantulas. Not even many snakes. No tortoises, alas.

Charmaine Parker

Play all the Goys

of the Holiday Season.

be Yours Today and Otluays

$$
1633 \text { Red cliff }
$$

87 EA 019

66

90026 


\section{DESERT TORTOISE PRESERVE COMMITTEE, INC. P.O.BOX 453, RIDGECREST, CALIFORNIA 93555}

Bureau of Land Management

7 December 1987

California Desert District

Attn: Mr. Gerald Hillier, District Manager

1695 Spruce Street

Riverside, CA 92507

Dear Mr. Hillier:

Thank you for the opportunity to comment on the 1987 Desert Plan Amendments. The Committee has comments on amendments 2 and 10 , plus rejected amendments 87-P-2 and 87-P-15. Our comments are as follows:

Amendment 2: Support acceptance of this amendment. Livestock grazing in this canyon has resulted in degradation of one of the best wildflower areas in this part of the Sierra. The visitor use of the canyon to enjoy the plants is very heavy in the spring. Cattle should be removed from competition in this area.

Amendment 10: Urge rejection of this amendment. Major conflicts will occur between cattle grazing and wildlife if perennial forage utilization is authorized. The cattle operation must be monitored closely by the Bureau to assure that there are not too many cattle already on the range to be exceeding the ephemeral carrying capacity of the allotment.

Pejected Amendment 87-P-2: We are very disappointed that the Bureau has rejected this proposal. The Bureau studies have conclusively shown the serious population declines here and in the surrounding region, and the relation of off road vehicle use to those declines. This area is critical to the Bureau goal of maintaining a viable, stable tortoise population in the western Mojave desert. The inability of the Bureau to effectively designate and enforce route designations in the Fremont Valley shows that another approach should be taken. This proposal is a reasonable

20-1 approach to managing the geographic area as a whole and not fragmenting the valley into unworkable management designations. Considering the population condition of this species, an expansion of the ACEC to the proposed area is a mandatory initial step. Minor adjustments to the boundary could be made after careful ACEC planning is completed, not the other way around. This proposal is consistent with the recommendations developed by the tortoise working group (led by Mr. Alden Sievers) for habitat management.

TRejected Amendment 87-P-15: This proposed amendment would have restricted camping in selected areas of high tortoise density. There has been no restrictions

20-2 placed on camping locations in tortoise habitat yet in the route designation process. Camping zones up to 300 feet on each side of all roads is a large area of critical -habitat which has heavy impacts by camping. This amendment and the one above 
were topics identified by most participants in the tortoise working group as high priority to improve habitat management.

We request a copy of your final environmental assessment.

Sincerely,

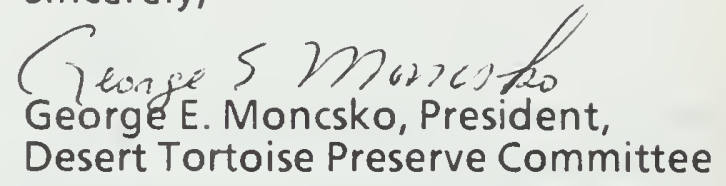


Response to Desert Tortoise Preserve Committee, Inc.

Response 20-1

See Response 11-1.

Response 20-2

See Response 11-2. 


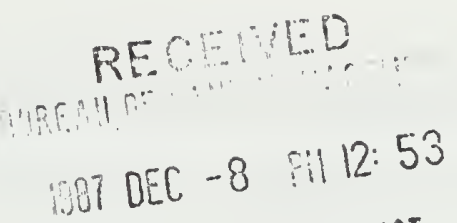

$$
\begin{aligned}
& \text { AHE BORICT }
\end{aligned}
$$

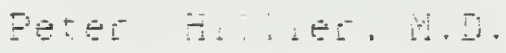

$$
\begin{aligned}
& 1112 \text { Ló Cadena hue. \#5. } \\
& \text { Arsada. Ca } 900 \\
& \text { Decentuer 6. } 1087
\end{aligned}
$$

Mr. Gerald E. Hillier. District Vianger

Callfornla Desert District

Bureau of Land Managemerit

ATTN: Plan Amiendments

1695 Spruce Street

Riverside, CA 92507

Dear Mr. Hillier.

This letter represents my input to your aepartiment re: The Callfornia Desert Plan.

I am a part owner of the jewell (or Gue:). Micn!gan. Michlgan \#2. Davenport. Red Top. Hermoss (ot Hermonie? mining clatms. Queenstake Resources (U.S.A.) Inc. holda a lease on these propertles and orher nearby cialms and has experided considerabie time, effort and money in exploration of them and other neardy cialms. Mlneable reserves are jndicated from the results so far and turtnet eyoraton is plannea.

- If restrictions under the Californa Desert Pian were to prevent Queenstake. Inc. Irom continulno thes eraevours it would have a regative flranclat lmpat on me. This $1 \mathrm{~s}$ a falr and legitimate concern for a person to noid.

I am writing therefore to endorse and urge adoption of

21-1 Queenstake. Inc. s (see their cor responcente) swgest ons for Calif. Desert Plan re: is modildaton of the pounaries of the Great Falls Basin ACEC and, 2) remoya Ot proposal io relinquish mineral r ghts in the Benko claims desplte their nearness to the Ruth silloified sheer zone.

I feel that the several overal! concerns of the calliornia Desert Plan will not be damaged by these moalidations.

of interest, though not pertinent to this letter. i cari remember as a youngster ilving at the Davenport mine when it was in operation.

Sincerely,

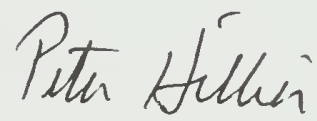

Peter Hillier. M.D. 
Response to Peter Hillier

Response 21-1

An ACEC allows for multiple use and mining may continue within the Great Falls Basin ACEC under conditions that will protect ACEC's resource values. 
December 7 agelin.

\section{Hisnge: $\because 2$ : 000 h Siers ras

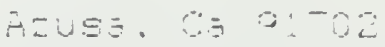

To: Gersia E. Hill ier

Distrlat mansoer

cialforna Deset. Distrat

ATTi: Plan mmitemanents

¿605 Soruce Sitreet

Flversiae. Co 5250 :

Llear Mr. Hill ler.

I an a part owrier of the Daverport sei les of ciang iogatea adiacerit to the Great Falls Basir. FCEC. J wow d ike to take this opportundty to express my conceris over the proposed ammendments to the Californla Desert Plan.

The bavenport propert.les were oi lolia: $\because$ alscovered and reglstered by my great-granamotner in tne esti iogd s. and have cemalned in the tamily ever sire. consicezale etfort nas been spent in the last elanty yejrs ro mantan ine clalms durirg times of both prosperlty ard depegenor.

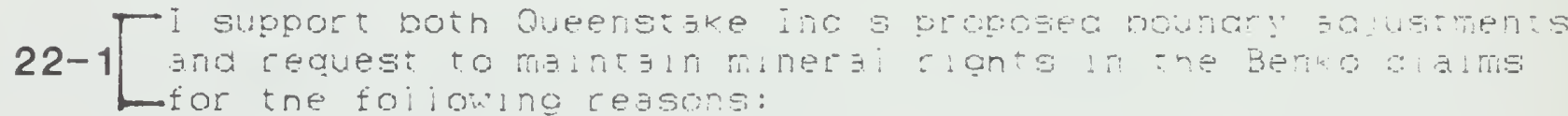

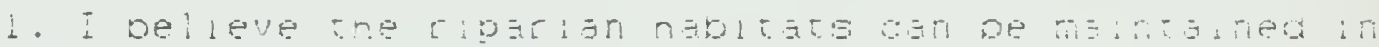
spite of cominueg exploration.

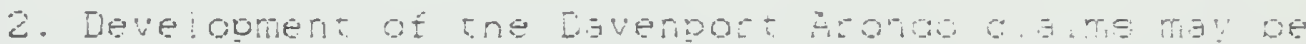
nampered without the amiended rorters bovosed ny

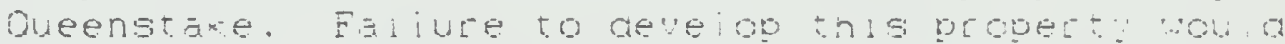
nave conslderabie ecorionilo imojot cri not .

3. Any mining activity would be of tanicial heip to both Trona and lis population.

Thank you for vour considerat lon or thls matter.

Sincereiv.
MTliti-

Hande: Hill let 
Response to Michael Hillier

Response 22-1

See Response to 21-1, 24-1 and 24-2. 
$87 E A-02^{3}$

$$
\text { RED }
$$

California Desert District of -9 m: $1: 16$

Bureau of Land Management

Attn: Plan Ammendments

1695 Spruce Street

Riverside, CA 9250'7

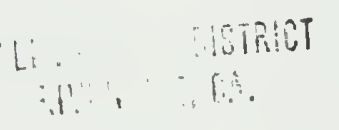

December 7, 198

$$
\begin{aligned}
& 225 \mathrm{~N} \cdot \mathrm{K} \text { St } \\
& \text { needles, CA } 92363
\end{aligned}
$$

Dear Sir;

I did not receive a copy of the plan ammendment book until 10 days after the Ridgecrest public meeting to discuss these plan ammendments. I am writing concerning ammendment no. 10. This allotment was an ephemeral-perennial allotment rated for 150 cattle per month at the time I purchased it from the previous owners. The BLM officer, Elmo Roundy, when writing the ownership change papers, asked us to change it to ephemeral, as it would be better for us financially at that time. He stated to me and William E Evans and Lucille T. Brown, former lease holder, that the lease could be changed back at any time, with no problems.

Running on an ephemeral lease is too unstable, not being able to make any financial plans for more than three months at a time, and would cause terrific hardship by not being able to market. our cattle at the proper time of year.

I am enclosing an old billing showing twelvemonths authorization livestock numbers for twelve months.

I wouldlike to comment on pages 4-12 and 4-13. The book states Ashift of leasees operation into the Piute Range would heighten stress-related impacts on desert bighorn sheep and livestock do not spend much time in that area at present. The country that the sheep use is mostly the top half of the Piute Range. 23-1 The sheep waters are totally unaccessible by the cattle. Therefore, there is no competition for water or feed and NO possibility Lof disease transmission between cattle and sheep on that mountain Frange. I will have to contradict the statement about livestock not spending much time in the Piute foothills, as they spend

23-2 at least 7 or 8 moN ths per year on the west side of the water line and up into the foothills of the Piute range, and have, for twenty or more years. The country the cattle use most of the time is too rough and rocky for the desert tortoise habitat.

\footnotetext{
-Page 4-14. The possibility of non-use of the water line would cause wildlife to suffer greatly, as the pipeline is approximately 7 or 8 miles long and supplies four water troughs and two dirt ponds which are resting places for ducks and geese and several other types of water fowl not to mention other desert wildlife.
}

Thank you for reading this.

A concerned desert rancher, 


\section{Response to Joe Evans}

\section{Response 23-1}

Although there is no apparent conflict between cattle and bighorn sheep in this allotment now, increase use of perennial areas in bighorn habitat could increase the possibility of disease transmission and stress. The means of disease transmission is not yet known; the lack of competition for food and water may not eliminate problems with disease.

\section{Response 23-2}

Much of the area west of the pipeline is ephemeral. Moreover, there are significant areas in the foothills that remain unused. Cattle are also forced to regularly return to the lower portion of the allotment to water, especially in the summer. This increases the likihood that perennials in the lower elevations will be overused, due to the yearlong presences of cattle. The development of an additional watersource along the powerline (currently in the planning stages) will only partially correct these problems.

Response to $23-3$

All actions taken to reduce water flow on the pipeline wil be evaluated in order to ensure that wildlife needs are met. 
Head Otfice:

Reno, Nevada Office: 9th Floor, 850 West Hastings Street Vancouver, B.C. V6C $1 \mathrm{E} 1$ Telephone (604) 684-1218 Telex 04.508875

P.O. Box 50098 Reno, Nevada 89513 Telephone (702) 356-3888
December 8, 1987

California Desert District

Bureau of Land Management

1695 Spruce Street

Riverside, California 92507

Re: 1987 Plan Amendments

Great Falls Basin ACEC

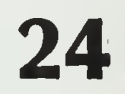

Queenstake Resources U.S.A. Inc. would like to submit the following confinents and recommendations concerning the proposed 1987 amendments to the Cal ifornia Desert Conservation Area Plan, as provided for by the period of public review of the environmental assessment. The proposed amendments of specific interest to Queenstake Resources are Amendments Number 3 and 7, involving the Great Falls Basin ACEC.

Queenstake has conducted exploration for precious metals in the Argus mine district over the past six years. Through four separate leases and additiona) locations, Queenstake controls over 250 unpateneted mining claims in the Argus district, a historic gold mining area within and adjacent to the Great Falls Basin ACEC. A 5,000 foot reverse circulation drilling program was completed in November 1987 on the Davenport and Orondo vein systems in the northern portion of the Argus district to further define ore reserves indicated by previous surface and underground exploration. Baseline environmental and pre-feasibility engineering studies are planned in 1988, should the drilling results merit a production decision.

Two of the proposed amendments to the California Desert Plan involve the Great Fal Is Basin ACEC. Amendment Number 3 proposes changes in the boundary of the ACEC, and Amendment Number 7 proposes the sale of several parcels of I and within the ACEC in Homewood Canyon.

Queenstake Resources recommends that Alternative B for Amendment 3 be accepted to remove the Homewood Canyon residential area and the Argus mine district from the Great Falls Basin ACEC. Queenstake and its Lessors believe that the Northern portion of the ACEC should be returned to the BLM multiple use -classification as the area has been a center for mining activities since the 1880's and is not a part of the Great Falls Basin wilderness study area in either aesthetic or geographic settings, and is primarily of residential

24-1 and industrial value. The Inyo brown towhee habitat is protected by the U.S. Fish and Wildlife Service and the California Fish and Game Commision, and therefore will not be adversely effected by this boundary change. 


\section{4-1 $\begin{aligned} & \text { Queenstake recommnended a different boundary modification in } 1986 \text { when the } \\ & \text { plan modifications were first put up for public review (see enclosed letters), } \\ & \text { and we were wondering why these comments were not considered or addressed }\end{aligned}$ \\ Lin Appenix B or $C$. \\ In regard to Amendment Number 7 , Queenstake opposes any Iand sales in the Homewood Canyon areaand supports rejection of this amendment. The residents with lifetime leases will be allowed to continue to occupy their homes ac- cording to BLM policy, and the potential for future minerals development on these parcels will not be adversely effected. \\ I would appreciate being kept informed of any and all BLM actions and pro- posed actions concerning the California Desert Plan. Queenstake was not notified of the public meetings in Ridgecrest in October 1987 and was not sent a copy of the proposed amendments, even though we are the largest property holder within the Great Falls Basin ACEC in terms of mineral claims.}

Sincerely,

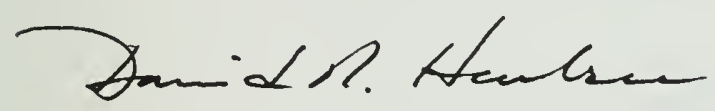

David R. Hembree

Exploration Manager U.S.

CC: Gordon Gutrath

Barrie Childs

Marion Dair

Fred Austin

Charmaine Parkes

Elwood Nutter

The Ima MacPherson 
Response to Queenstake Resources (U.S.A.) Inc.

Response 24-1

Management of ACECs by the Bureau calls for multiple uses to continue to the extent that the key natural resource values are not jeopardized. An ACEC designation is both a recognition and protective classification, and provides for focused Bureau management attention to assure that the key values are protectively managed.

Significant portions of the habitat for the Inyo brown towhee occur north of the Great Falls Basin Wilderness Study Area and these habitats are removed from the private land that is used for residential purposes.

\section{Response 24-2}

Quecnstake Resources (USA), Inc. 1986 comments on the draft ACEC management plan for the Great Falls Basin ACEC were carefully considered. Since the ACEC does not preclude multiple land uses, including mining, there is no justification to change the boundary. The ACEC designation is both a recognition and management classification that provides for proper Bureau management attention to assure the continued existence of the key resource of the area, namely scenery and wildlife. To date, the ACEC designation and Bureau management actions have not constrained the mining operation proposed by Queenstake Resources, Inc. 


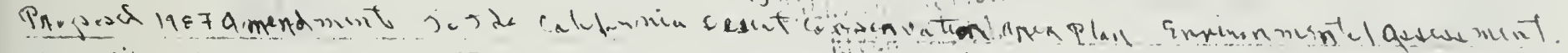

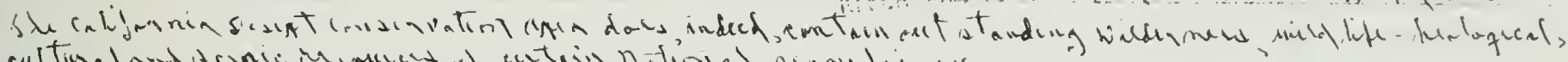

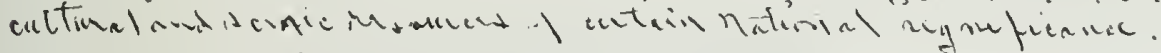

Dispertainul mut ese (1):

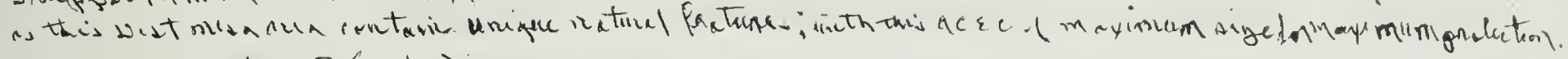

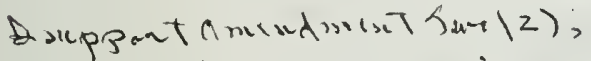

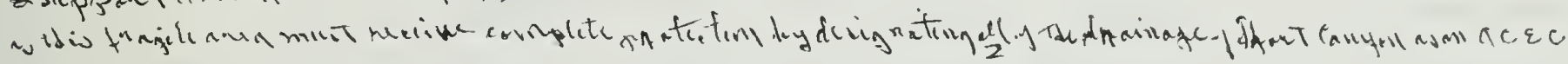
a.te 1 mund nust 5 hine $(3)$ :

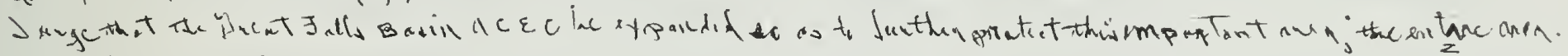
conec...iving (musdnust Jaik/4);

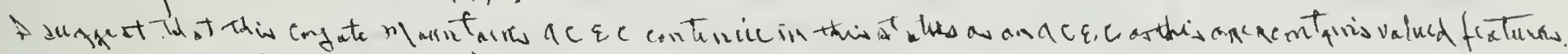

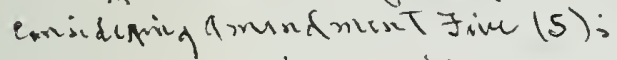

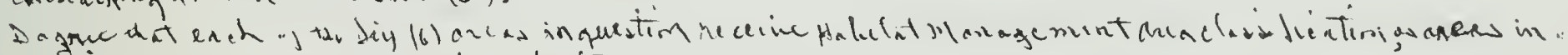
quetion prodist inppessive ratural featius

as $x_{n}$ (mund mint siy (6);

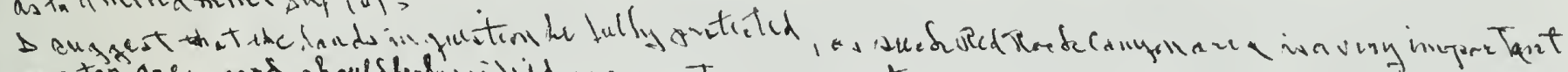

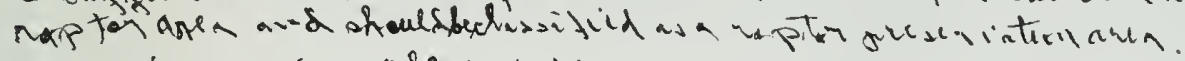

concenningamendment siven (7):

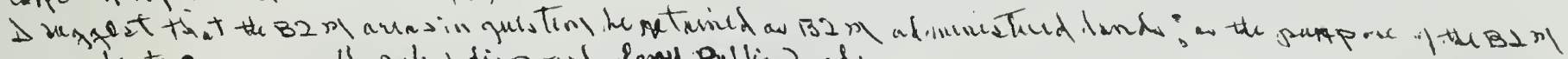

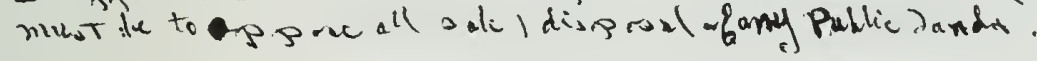

art. nmundmut kight $(8)>$

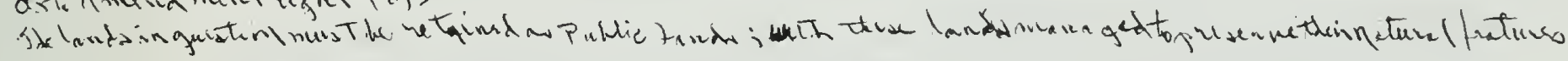

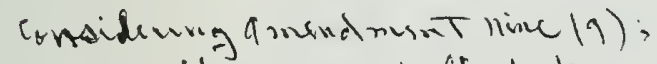

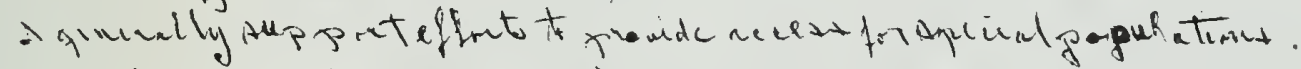

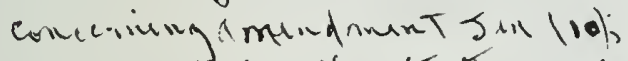

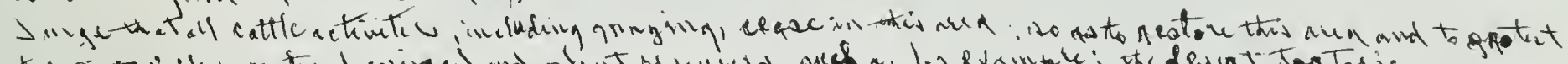

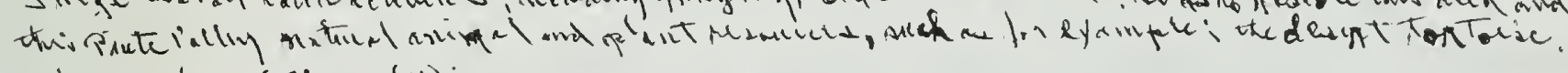

asto anudrunticlom (II);

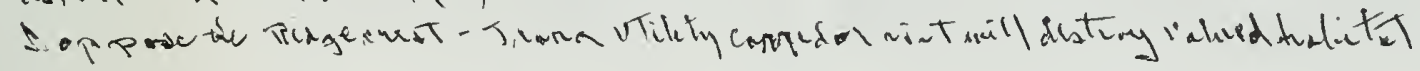

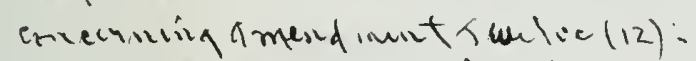

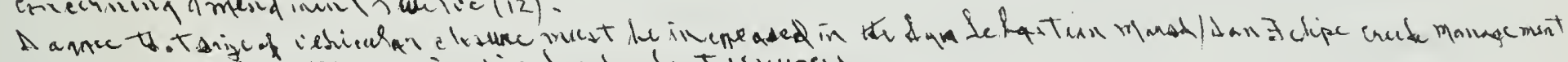

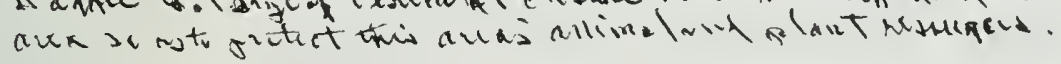

Sinecrity?

DSili. Sunasen. 
P.0. Box 307

Boron, CA 93516

December 8, 1987

California Desert District Bureau of Land Management ATTN: Plan Amendments

1695 Spruce St. Riverside, CA 92507

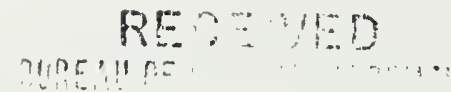

ISOP OEC 10 fil 1: 22

SUBJECT: Comments on proposed amendments to CDCA Plan

Amendment I -- I support the proposed ACEC Boundary.

Amendment 2 -- I strongly support this new ACEC... I am well aware of the diversity of plantlife in the area.

Amendment 3 -- I support the alternative that will include more springs and riparian habitat, but exclude Ruth Mine.

Amendment 4 -- Your pleasure.

Amendment 5 -- Alternative B sounds plausible PROVIDED livestock is controlled (ELIMINATED!) to protect waterholes and forage for the bighorn. Also, consider the bighorm herd more appropriate for the area than wildhorses and burros.

Amendment 6 -- I support Class I designation...positively:

Amendment 7 -- Your pleasure

Amendment 8 -- Suggest you determine to what degree the desert tortoise would be affected. You contradict yourself by saying "no threatened animal species are known to exist in the affected area"

Amendment 9 -- By "special populations" I presume you mean ORV's? We don't need to enlarge upon "opportunities available in the desert"!

Amendment 10 - First thing that should be done is to PHASE-OUT the grazing allotment. Then, reject the amendment.

Measure 10-1 good

Amendment 11 - Anything you do is detrimental to wildlife:

Amendment 12 - I support Alternative A.

Sincerely,

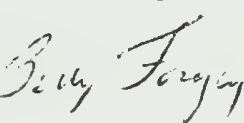

Betty Forgey 


\section{$\quad 87 E A \quad 027$}

THE UTAH DESERT TORTOISE COUNCIL

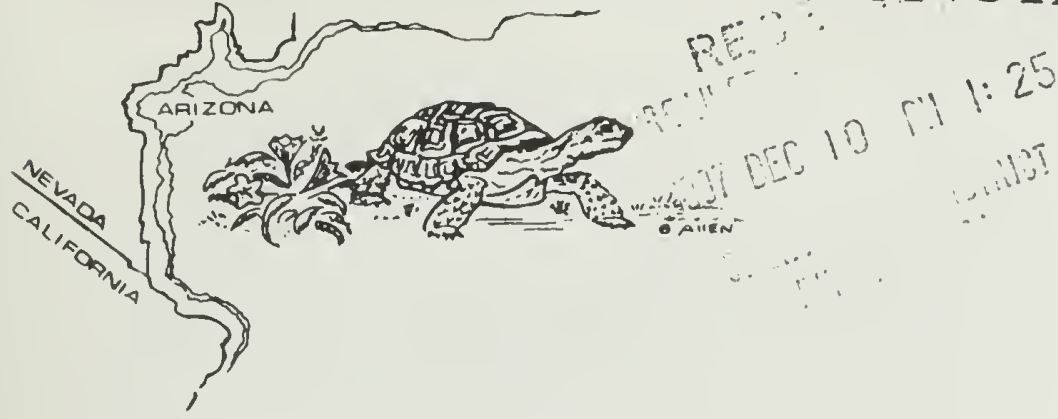

5319 Cerritos Avneue Long Beach, CA 90805

December 9, 1987

Mr. Gerald Hillier, District Manager

California Desert District

Bureau of Land Management

ATTN: Plan Amendments

1695 Spruce Street

Riverside, CA 92507

Dear Mr. Hillier:

The Desert Tortoise Council (DTC) is pleased to respond to your request for comments on the 1987 Desert Plan Amendments.

Amendment 10: We support your rejection of this amendment. If the Piute Valley allotment is changed from ephemeral to ephemeral-perennial status, the desert tortoise population will be in jeopardy. We do not believe that this type of desert habitat can withstand ephemeral-perennial grazing pressure and at the same time sustain a healthy desert tortoise population. Studies conducted by the Nevada Department of Wildlife on the Crescent Peak Allotment in the Piute Valley have revealed that overgrazing contributed to a major die-off of tortoises in the early 1980's. The Bureau should take such information into account in rejecting this amendment.

Amendment 87-P-2: We protest the dropping of this amendment, which dealt with expansion of the Western Rand Mountain ACEC. Prroposed by the Desert Tortoise Preserve Committee, this amendment provides the best method of preserving and protecting the declining totrtoise populations in the Rand-fremont Valley area. The Bureau states that expansion of the Rand ACEC is premature, ...prior to prepartion of the ACEC management plan." The Bureau has had seven years to prepare a plan and has

- not done so. Even if the Bureau prepares a draft plan by October of 1988, many more years will be required to finalize and implement it. The tortoise populations cannot wait for plan drafts, plan finalizations, plan amendments, etc. Action is needed now! Data from the Bureau's own study site in Fremont Valley show that the population has experienced serious and significant declines beteween 1979-81 and 1987, and that the declines are related to human use. The Bureau often has been accused of "planning to plan." This is a prime example of such lack of action.

Amendment 87-p-15: We also protest the dropping of this amendment, which would require all vehicular traffic to remain on existing roads within the Bureaus five areas of crucial desert tortoise habitat. Crucial tortoise habitat should receive maximum protection from off-road vehicle impacts. We believe that this amendment, or a modificaion of it to include at least the Western Mojave crucial habitats, is essential to protecting and stabilizing tortoise populations. The Bureau has demonstrated that populations are declining at a very rapid rate in the Western Mojave Desert, and it should take emergency actions to stabilize the populations. This amendment, or a modification of it, would 27-2 definintely help to achieve stabilization. We have yet to see evidence that the Bureau is dedicated to protecting the tortoise through the vehicle route designation process. In fact, we want to again point out that we have not been included in this process.

Sincerely,

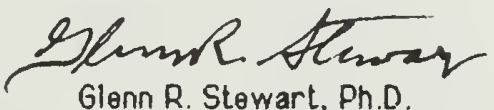

Glenn R. Stewart, Ph.D.

Senior Co-Chairman xc California Department of Fish and Game

U.S. Fish and Wildlife Service

DTC Board 
Response to The Desert Tortoise Council

Response 27-1

See Kesponse to 11-1.

Response 27-2

See Response 11-2. 
3501 Pageant Drive

Sacramento, CA 95826

9 December 1987

California Desert District, BLM ATTN: Plan Amendments

1695 Spruce Street

Riverside, CA 92507

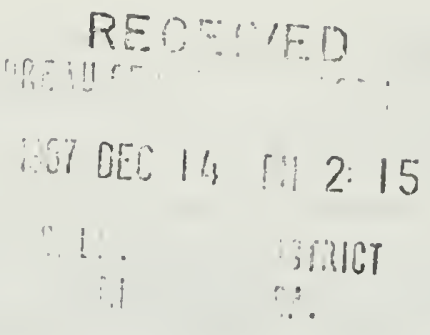

28

Dear Mr. Hillier,

In comment on the pronnsed 1987 amendments to the california Desert Plan, I concur with your Preferred Alternatives to accept Alternative $A$ on $\# 1,2,3,5,8,9,11$, and very strongly on \# 12, and also accept $B$ on \#10.

Your chart on P. S-4 states no impacts on botany or wildiife , or from geology, energy, mineral classifications in the Red Rock amendment. Yet there are impacts.

- I accept AMENDMENT \#6 as far as it goes in the direction of protection. Your proposal for NIGHTMARE GULCH, however, is inadequate. You pronounce the area as valuable, and in need of seasonal protection for nesting raptors. I am aware, though, that OHVs have ignored this, and have driven through in nesting season, driving birds off. This says to me that the Gulch should be off limits year round.

- You do not mention Rare and Endangered plant species Hemizonia arida and Chorizanthe spinosa, among others, which

28-2 I have personally seen in Nightmare Gulch CRUSHED by OHVs! In addition, the unusually beautiful Nightmare Gulch canyon floor has been compacted and crushed by the the OHVs, and thus visually destroyed!

- Fd Hastey told me over a year ago that Nightmare Gulch would not be transferred to Red Rock State Park because of mineral

28-3 rights in the area. While you state there are some mineral claims, and that there is a low potential for sand and gravel, you seem to justify general OHV access to the Gulch - because of the mineral claims. I do not find this acceptable. I would also hope that the intricately-formed canyon walls of Nightmare Gulch not be considered as mere heaps of sand to be mined.

Nightmare Gulch is THE truly spectacular area of this entire piece of land. It should be included in the transfer.

Thank you for this opportunity to comment.

Yours sincerely,

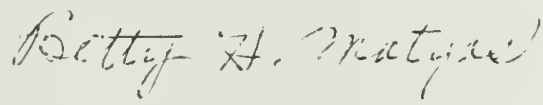

Bet ty $H$. Matyas 
Response to Betty H. Matyas

\section{Response 28-1}

From February 1 to July 1 all public entry is prohibited in Nightmare Gulch. This six month closure was in effect in 1987 and continues as a permanent, seasonal use restriction. This closure has been enforced by both BLM and state Parks rangers with excellent compliance.

Response $28-2,3$

While ORV's are allowed on the existing route in the canyon botton, they are restricted to the established route to insure that no plants are damaged. The limited seasonal vehicle use is allowed, since this is an established 4-wheel drive route which people enjoy traveling. 
29

87EA-029

December 8,1987

turjict: Short Lingon ACEC

Fian inneselonent, tepfort- of

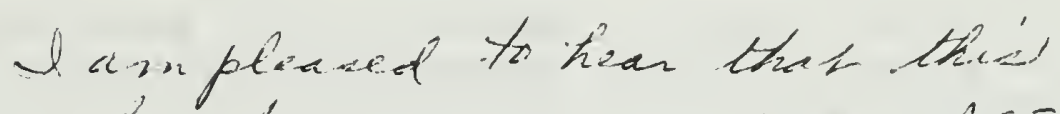
Wisa has been nominated for ACEC statur. Euring my 28 years sesilense in Fidgowest lizea, of epent smany. happy hous there. It was my fevorite spot in the lise and is well deserving of epeciel statur becacese of the chundence of special evildflowers and prime njosicen hobitats.

Orien the last canturay of wee,

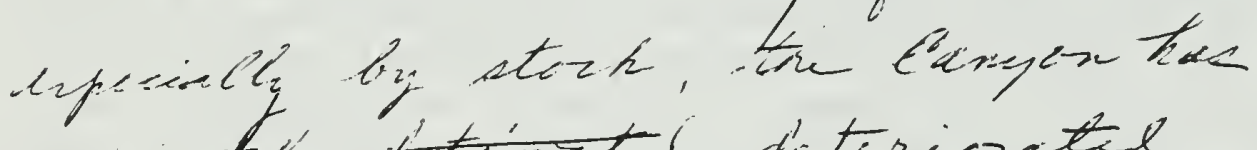
cupintily citionted diterionatel. of cuosild hope that an AC.EC cusipaction would poinde protaction for a unique asia and thecs to a hait of cintinued destruction.

finearely,

cavel Penlagen

C. Panlaqui
630 Plaza Amigo

Palm Springs, CA 92262

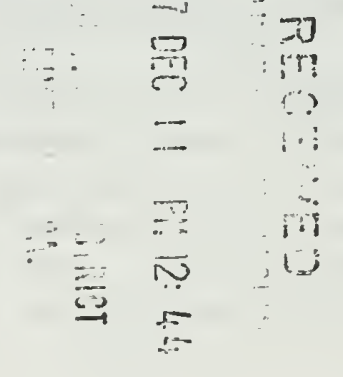

85 


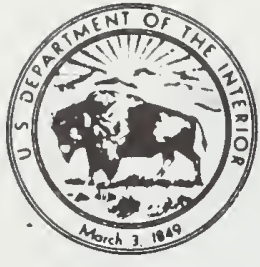

Department of the Interior

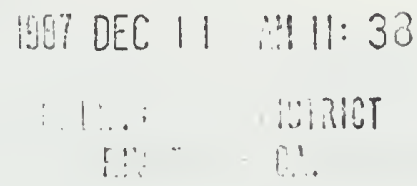

Fish and Wildlife Service

Lloyd 500 Building, Suite 1692

500 N.E. Multnomah Street

Portland, Oregon 97232

In Reply Refer To:

Your Reference:

Memorandum

To: State Director, Bureau of Land Management, Department Acting

of the Interior, Sacramento, California

From: Assistant Regional Director - Fish and Wildlife

Enhancement, Fish and Wildlife Service, Department of

the Interior, Portland, Oregon

Subject: Review of Environmental Assessment, Proposed 1987 Plan Amendments to the California Desert Plan

The U.S. Fish and wildlife Service (Service) reviewed the subject Environmental Assessment that addresses 12 proposed amendments to the California Desert Plan. Our specific comments on individual amendments are as follows:

Amendment No. 1: We strongly support the adoption of this amendment for the protection of the flat-tailed horned lizard (Phry-

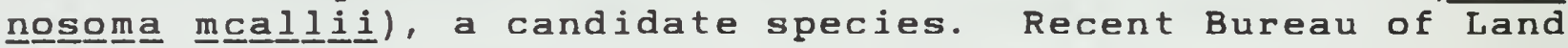
Management (Bureau) funded field studies have documented the relatively rare occurrence of this species. A report completed for the California Department of Fish and Game also clearly shows that the major portion of the geographic range of the flat-tailed horned lizard is subject to one or more potentially conflicting uses. Retention of blocks of land for protective management is a necessary measure for ensuring long-term species protection. Development of an Area of Critical Environmental Concern Management Plan, detailing measures to protect, enhance, and monitor horned lizard populations should receive a high priority by the Bureau. As noted on page 4-1 of the Environmental Assessment, designation as an Area of Critical Environmental Concern entitles an area to receive the highest Bureau priority for monitoring and funding. This increased management would greatly benefit the important wildife resources of Short Canyon.

Amendment 3: We strongly support expansion of the current management area boundary under Alternative A to incorporate additional, currently off-site, riparian habitats utilized by the Ffederally-listed threatened Inyo brown towhee (Pipilo fuscus eremophilus). We do recommend, however, that the proposed addi30-1 tion be slightly expanded to include all designated critical habitat outside of the China Lake Naval Weapons Center. 
30-1 $\begin{aligned} & \text { Incorporation of these areas into the Area of Critical Environ- } \\ & \text { mental Concern boundary should provide for consistent habitat } \\ & \text { management on Bureau-administered lands and decrease the oppor- }\end{aligned}$ tunity for incompatible land uses.

Amendment 6: Change of multiple use class designation of 2,164 acres adjacent to Red Rock Canyon State Park from unclassified to Class $L$. We urge the Bureau to accept this amendment. As noted in the Environmental Consequences section of the Environmental Assessment, the public use limitations available in Class L lands would provide better management opportunities for resource values. Restrictions on vehicular travel and other management requirements resulting from this designation should greatly benefit the area's wildlife resources.

Amendment 7: Changing the multiple use class of two parcels of land within Homewood Canyon from Class L to unclassified. Deletion of the parcels from the Great Falls Basin Area of Critical Environmental Concern. We strongly urge the Bureau to reject this amendment. The springs on this land support the Inyo brown

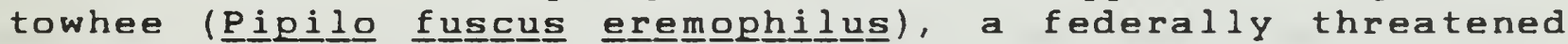
species. The tapping of the springs by the residents has already reduced the size and health of the riparian areas around the springs. Allowing the residents to own the land would enable them to increase impacts to wildlife resources, including further development of the springs. Private ownership would also preclude enhancement of the spring habitat upon the expiration of the 1 ifetime leases of the current residents.

Amendment 10: Changing Piute Valley allotment from ephemeral to ephemeral-perennial. The Service recommends rejection of this amendment. The amendment appears to encompass more than the bookkeeping change claimed by the proponent. Development of water sources in the Piute Range would draw cattle into this area and create grazing impacts to additional areas. These would include direct conflicts with desert bighorn and mule deer and probably indirect impacts on golden eagles and other raptors.

Amendment 12: We strongly recommend acceptance of this amendment for the protection of the federally-listed endangered desert pupfish (Cyprinodon macularius) and for several candidate species. Given the current violations of vehicle restrictions, expansion of motorized vehicle closure areas is necessary. Acceptance of this amendment should also serve to more clearly delineate vehicle restriction zones and to improve law enforcement capabilities. 
-Preliminary Amendment 87-P-2: We recommend that the Bureau reconsider adoption of this amendment. Given the intense and widespread use of the Fremont Valley by off-road vehicle enthusiasts and the inability of the Bureau to control this use using the route designation process, Area of Critical Environmental Concern designation is clearly warranted. The area is extremely important to the long-term perpetuation of the desert tortoise (Gopherus agassizii), a candidate species. Numerous studies have documented the incompatibility of off-road vehicle use with wild-

30-2 Iife and associated habitat protection. Rather than defer Area of Critical Environmental Concern boundary adjustments pending development of a management plan, it is far more prudent to immediately expand the existing boundaries and consider expanded boundary 1 ine modification during subsequent management plan development. This action places the necessity for immediate plan development on recreational and other resource-impacting interests, while affording increased levels of protection to the desert tortoise and other sensitive species.

Preliminary Amendment 87-P-15: We recommend that this amendment should be reconsidered for adoption by the Bureau to afford increased levels of protection to the desert tortoise. The current 300-foot-wide vehicular camping provisions in the Desert Plan pose a significant impact to this species through direct mortality and indirectly through habitat degradation. Although 30-3 such provisions can be incorporated into the vehicle route designation process, this process is nearly complete within high density desert tortoise areas in the California Desert. An amendment addressing this problem on a region-wide basis is also more logical than in a site-specific "piecemeal" fashion.

Thank you for the opportunity to provide comments at this time. If we may be of further assistance, please contact Ted Rada (Sacramento Endangered Species office, FTS 460-4866) or Ray Bransfield (Laguna Niguel Field Station, FTS 796-4270).

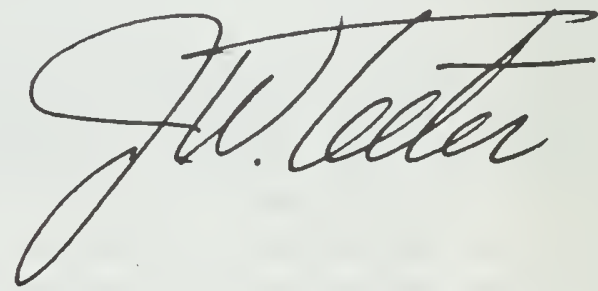


Response to U.S. Fish and Wildlife Service, Portland

Response $30-1$

Designated critical habitat on Federal land has been included within the management area.

Response 30-2

See Response 11-1.

Response 30-3

See Response 11-2. 


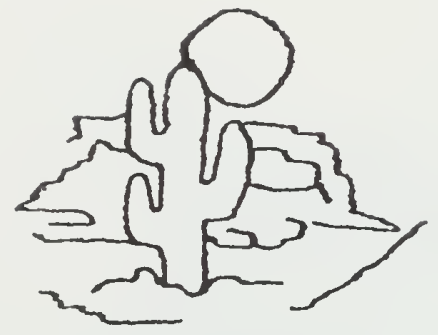

\section{HIGH DESERT MULTIPLE-USE COALITION}

\section{P.O. BOX 1167, RIDGECREST, CA 93555}

California Desert District

Bureau of Land Management

1695 Spruce Street

Riverside, CA. 92507

Dear Mr. Hillier:

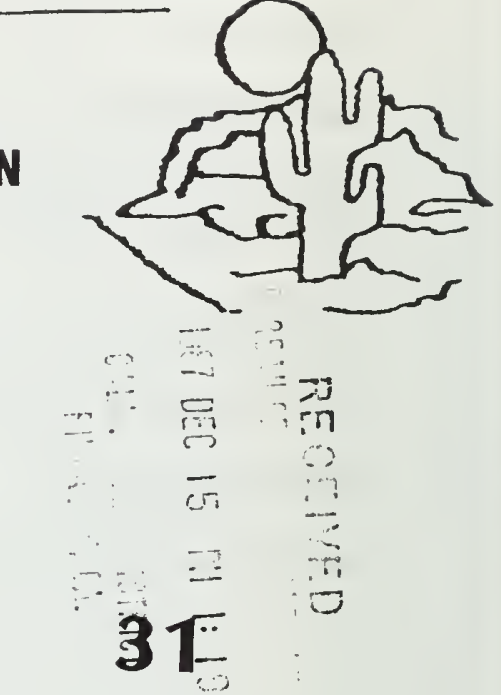

After attending the Desert Advisory Council meeting in Ridgecrest, we would like to submit the following comments:

\section{Short Canyon ACEC-armendment \#2}

Although we feel that the protection of this area has already been addressed through the allotment management plan, we are in support of designating this area as an ACEC, providing that the existing vehicular access routes remain intact.

\section{Great Falls Basin ACEC-ammendment \#3}

We very strongly support the acceptance of alternative $B$ and feel that this addresses the concerns of most people by allowing the protection of the existing ACEC while providing a greater opportunity for a wider range of multiple-uses. After reviewing a considerable amount of documentation and contacting several knowledgeable individuals associated with the Naval Weapons Center (NWC), as well as the author of the latest studies concerning the Inyo Brown Towhee, we feel that this species is adequately protected by the existing ACEC and the ultimate protection of the NWC boundary.

\section{Wildlife Habitat Management Areas-ammendment \#5}

While we are very much in support of any management activity to enhance wildlife, we have some concerns reguarding this proposal particularly the White and Inyo Mountains.

After reviewing the Inyo-White Mountain Deer Herd Management Plan, we believe that the appropriate problems are not being

31-1 addressed. This plan repeatedly implies that the major factor detrimentally impacting the deer population is the lack of predator control. This is frequently indicated throughout the plan Examples include: 
pg. 11 Mountain lions are known to subsist primarily on deer (Connolly 1981)

Deer may constitute a major portion of coyote's diets (Connolly)

pg. 24 It is quite likely that predators take a substantial number each year especially fawns

pg. 25 Numerous studies in California and elsewhere have shown that predators take many apparently healthy fawns from study population

There are some cases where the removal of coyotes from 3 study sites increased the fawn survival an average of $154 \%$

Although it seems possible that a sufficiently wide spread predator control program would increase fawn survival, at least temporarily, it is not being suggested for a number of reasons. Preảator control for increased aeer numbers has not been practiced by the DFG for many years. Although current fish and game policies allow for predator control to increase cieer numbers, public opinion may be strongly opposea to such practice especially on juolic Ialli.

pg. 29 Even if prealation is determined to be a major cause of fawn loss on spring and summer ranges, control of preàators cioes not appear to be a viable option for a number of reasons.

This plan clearly implies that the removal of grazing is not the aesired option but a secondary choice and might not improve the existing concitions appreciably

Examples inclucie:

pg. 33 Given present knowlecige, the greatest likelihood of increasing fawn survival is the elimination of grazing on riparian habitat. It is not known for certain that elimination of crazing in this particular area wolila improve habitat so that substantially more fawns would survive but this is a reasonable assumption based on data from other lccations

Controlling precators that probably take a substantial number of fawns is not practical uncer present circumstances, ano would not be supported by the 
USFS or BLM without strong public support. Public sentiment probably would not be in faver of preciator control on public lana's to increase the number of deer in the hunter's bag. Although mountain lions could be controllea by hunting with dogs it is likely that the only means of controlling coyctes would be with a wiảe-spreac poisoning program which woulà be very expensive.

Consequently, based on current knowlecige, the most likely possibility for an increase in fawn survival is the elinination of cattle grazing.

From personal observations we disagree with the conclusions that grazing is substantially degrading the deer habitat. We are aware of numerous areas where the riparian cover is extensive and aifficult to penetrate by an indivicual on icot. Over the last several years we have noted an alarming increase in the evidence of predation. This year during our casual recreational visits to this area we happenea on to numerous preciator kill sites and founc several locations where young mountain lion cubs apparently dieć a few months after birth. Later curing deer season we observed a dramatic cirop in the number of adee with fawn, even though the number of doe remained relatively the same. This year we spotted only one aoe with twin fawns while in the past years twins were very common. Due to informaticr received. from a DFG biologist we cio not attribute the lacking fawn numbers to inappropriate buck to doe ratio. Nor do we attribute these lacling rumbers to the extremely dry season because these observations were macie in an excellent habitat area acijacent to a running stream.

After persuing more information from other DFG persornel we feel that some of the information contaired in the 1987 Proposed Desert Plan Ammendment literature is misleading. The Desert Plan - Armencrient text implies that there is consicierable competition between cieer and cattle for fcoc aná space, however, we have been. informed that this is not the case in the White and Inyo mountains.

31-2 This is also discounted by the deer herc management plan which sites the lack of local crop cierrecation as an incicator. The Desert Plar Ammeriment ciescription suggests that cattle and ceer - are socialiy incomoatatible, however, this point has been proveo false and true by many experts. We have observed on numerous occāsions deer reacily grazing among cättle when other acjjacent areas remained unoccupiec. At other locations we have notec that the absence or preserice of cattle has no bearing on the number of ceer utilizing the crazing. The ammencment cescription implies that bighorn sheep cannot be reintrociucec until this propsal is intact. However, the deer herd manacement plan notes an existing

31-3 population on Cottomicoci Creek and the Write Mountain Peak Bighorn Sheep Pooulation : 1987 Status report inaicates that these sheep are alreacy present and doing cuite vell on White Molintain Peak. 
According to the DFG in Bishop, cattle are not posing any threat to the sheep population and it will not be necessary to close any existing vehicular access to protect the wildlife habitat. It was however, indicated that several roads in Saline valley area have been questionably closed by the BLM in the claimed interest of the bighorn sheep. Therefore, we are strongly opposed to the closing of any vehicular access routes because there are very few in this area and they receive extremely light recreational useage. The desert plan ammendment clearly states that water developments for cattle are imparing the wildlife habitat but on page 3-12 it clearly states that water development would likely extend deer use. Why do you consider water development for cattle unuseable by deer? We have witnessed on numerous occassions deer using watering facilities intended for cattle and during extremely dry years these spring developments are desperately needed for all wildlife.

Another area of concern addressed by the desert plan ammendment proposal is the protection of wild trout. The White and Inyo Mountain Ranges contain no native wild trout species, however, The Paiute Cutthroat Habitat Management Plan and the Paiute Cutthroat Recovery Plan indicates that there is a small population of these trout located in the north fork of Cottonwood Creek ahove Granite Meadows in the Inyo National Forest. These trout were relocated in 1946 by the DFG from the Walker River drainage. These plans propose that a section of Cottonwood Creek, extending 300 yards into BLM juristiction, be chemically treated to exterminate the existing trout for the reintroduction of the Paiute Cutthroat Trout. These plans also suggest the total eradication of all trout in the south fork and main course of the Cottonwood Creck for the reintroduction of Paiute Cutthroat Trout to allow a future fishery. Both studies indicate that the lower portions of Cottonwood Creek is a difficult habitat to manage because there is a lack of appropriate spawning gravel and will require the continual importing and washing of gravel. Both studies also state that due to their nature this species will not relocate to occupy their entire available habitat and will require constant manual relocation. Still another obstacle sited is the unwary nature of this trout species, which can only withstand very light angling pressure. These documents indicate two other existing populations in Birchim Lake in the John Muir Wilderness and the other in Cabin Creek in the White Mountains. Birchim Lake is an excellent habitat protected by the wilderness status with no established trails, no range allotments, no mining activity, and sparse recreational use. There have also been reports that this trout has attained lengths of 18 inches in this drainage but the DFG suspects that this population has been introgressed by other species. The other location, Cabin Creek, is also an excellent habitat with the existing spawning gravel, no beaver populations, no vehicular access, sparse recreational use, and meeting all requirements while allowing angling. The DFG suspects that this population was inadvertently introgressed during preparations for the relocation of this species

In light of the considerable shortcomings and apparent expense 
of managing the lower portions of Cottonwood Creek as a Paiute Cutthroat Trout habitat, we feel that the available manpower and expense would be more wisely utilized by promoting this trout's population in Birchim Lake and Cabin Creek. Another possible location might be the Inyo National Forest Service's proposed Research Natural Area in the White Mountains. The utilization of these other areas might well save this species in the event of some unforeseen catastrophic event which damages the cottonwood

- Creek drainage habitat. We are very strongly opposed to the extermination of the existing trout populations in lower Cottonwood creek because it is the best vehicle accessible recreational fishery in the White Mountains and it is used as one of the few recreational opportunities of the residents of the remote Fish Lake and Deep Springs Valleys.

We wish to stress that we are not opposed to the formation of these HMA's, but we are concerned that they may not be managed appropriately and unnecessary vehicular closures may be enacted.

\section{Multiple Use Class Designation-ammendment \#6}

We wholeheartedly support your prefered alternative of accepting this ammendment and feel that this would aici in ensuring the multiple-use of this area. We are however, opposed to the closure of any of the existing vehicular routes in this vicinity.

5. Change the Multiple Use Class of Two Parcels in Homewood Canyonammendment \#7

We support the acceptance of this proposal because these residents developed these parcels and water sources 50 years ago at a time when this was perfectly legal. To deny these people their right to this property is a terrible injustice and we urge you to grant these people free and clear title to their property.

6. Recreation-ammendment \#9

We energetically support this ammendment and at the present time we do not have any suggestions to further this concept. We do, however, feel that this proposal is a step in the right direction but falls short of what could be accomplished. We would very much like to see this trend continued in future plans.

\section{Utility Corridor-ammendment \#11}

Due to a current cease and desist order from the Lahotan Water Resources Board, this utility corridor is desperately needed to 
allow the sale of waste water to the Kerr McGee Facilities near Trona. This is consistent with the need to recycle as much as possible our natural resources and would serve to protect the environment and water supply of the Indian Wells Valley while ensuring that possible water sources near Searles Valley do not require explortation. There is also a very possible future need to transport domestic water from the Los Angeles Department of Water and Power Aquaduct for use in the Indian Wells Valley and we urge your acceptance of this amendment.

We thank you for your valuable time and hope you will consider our concerns in evaluating these proposed ammendments to the desert plan.

Con diluter

Ron Schiller, chairman

Roger Nickels, Co-chairman

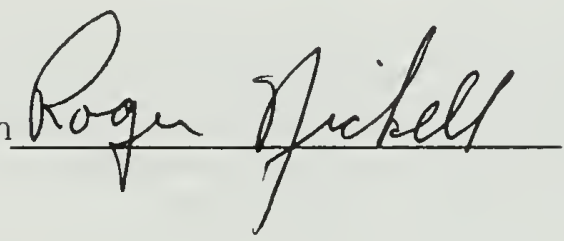

Mary Grimsley, secretary mary, o arimoley

95

(6) 
Response to High Desert Multiple-Use Coalition

Response $31-1$

This proposed amendment affects public lands managed by the BLM on the lower eastern slopes of the White Mountains and does not apply to the entire Inyo-White Mountains Deer Herd Management Area which also includes lands within the Inyo National Forest.

Due to the overlap of the deer winter range and livestock grazing allotments in this area, and the affinity that cattle have for aquatic and riparian habitats in arid environments, it is expected that development of management plans and actions for enhancing wildlife resources (deer, upland game, songbirds, fish and other aquatic organisms) can result in improved habitat conditions and populations of these animals. The cattle grazing season for a majority of the public lands bordering the portion of the area adjacent to the Inyo National Forest are from spring through summer. This fact coupled lwith the existence of the deer winter range, suggests there is good potential for both social and forage conflicts between cattle and deer in a portion of the allotment. Also, owing to the sparse distribution of water outside the streams and springs in the allotments and absence of any livestock control fences, there is strong potential for unnecessary degradation of aquatic and riparian habitats by cattle. These problems can be studied, documented and corrected through a habitat management plan.

Response 31-2

A wildife habitat management plan would provide for full evaluation of the effects of livestock on wildlife resources in this area on a site specific basis. Literature on mule deer ecology and management indicates there is potential for social impact on deer from cattle.

It is true that deer may use water sources developed for cattle, but this also depends on the location and amount of human and livestock use of the water source. Livestock water developments, if improperly designed and located, may impact natural water sources needed by deer and other wildlife or result in the trampling of necessary vegetation cover next to water sources to the extent that significant impacts to wildlife occur.

Response $31-3$

It is the policy of the BLM to complete wildlife habitat management plans before wildlife introductions occur in an area. Thus, a habitat management plan is needed before reintroduction of bighorn sheep can take place in the Soldier Pass - Piper Mountains area, as well as in the White Mountains on public land managed by the BLM. Habitat management plans are necessary to provide for planning, suitable habitat conditions and monitoring before the wildlife introduction.

The Department of Fish and Game has notified the Bureau of their intent to reestablish bighorn sheep in the Soldier Pass - Piper Mountain area and in a portion of the White Mountains. Introduction of bighorn into the Soldier Pass - Piper Mountain area is a high priority.

Establishment of the proposed Wildife Habitat Management Areas does not include proposals for closure of vehicle routes. 
Cattle water facilities may be used by deer, but not necessarily. The literature on mule deer ecology and management identifies potential impacts to deer and other wildlife due to the improper location and design of livestock water facilities. For example, it is considered improper land management to allow cattle to have access to riparian and aquatic habitat in arid areas for extented periods of time, especially during the growing season, and also to provide water for cattle next to these habitats without proper livestock controls. Likewise, it would be undesirable to develop livestock water facilities in important deer habitats where cattle and deer may be on the range at the same time. The BLM plans to develop water sources for deer in the winter range located in the northeastern portion of the Inyo Mountains between Cowhorn Valley and Waucoba Canyon in order to extend deer use of the habitat farther to the east. The potential locations of these water source developments are not within a cattle grazing allotment.

\section{Response to $31-5$}

Extermination of the trout population in lower cottonwood creek is not planned. Eradication of rainbow and brown trout in Cottonwood Creek above the natural fish barrier is planned by the Department of Fish and Game so that a population of Paiute cutthroat trout can be maintained. According to the Department of Fish and Game, lower Cottonwood Creek will continue to have a population of rainbow or brown trout to meet the needs of the angling public. 


\section{2

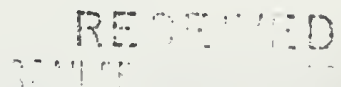

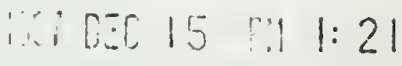 \\ THE WILDERNESS SOCIETY}

CALIFORNIA NEVADA REGION

10 December, 1987

32

Gerald E. Hillier

District Manager

California Desert District

Bureau of Land Management

1695 Spruce Street

Riverside, CA 92507

Re: Proposed 1987 Desert Plan Amendments; Environmental Assessment

Dear Mr Hillier:

Thank you for the opportunity to comment on the abovereferenced amendments to the California Desert Plan.

The Wilderness Society fully supports Amendments 1 - 3, and Amendments $6-12$. We support Amendment 5, but recommend additional action. We express several concerns with Amendment 4 .

Following are brief comments on each amendment.

Amendment $1-3$.

The Wilderness Society applauds the creation of new ACECs in West Mesa and Short Canyon as well as the boundary adjustment in the Great Falls Basin ACEC.

Amendment 4.

The Wilderness Society is concerned about this particular amendment.

While respectful of the skills of BLM Archaeologists who have conducted recent surveys, it is difficult to accept that an area was which was deemed culturally significant in the 1980 Plan now is shown to be absent such resources. Particularly in view of the fact that there is clearly an ORV conflict in the Larea. 
Gerald Hillier

10 December, 1987

p. 2

Finally, it is troubling that the BLM has allowed

32-2 $\begin{aligned} & \text { extensive ORV use of the Coyote Mountains ACEC, including } \\ & \text { organized competitive events each year. }\end{aligned}$

Amendment 5.

We support the creation of the following five Habitat Management Areas (HMA): East Slope White Mountains HMA, Soldier Pass - Piper Mountain HMA, Last Chance Range HMA, and Cowhorn Waucoba HMA. Additionally, we recommend the creation of the Sylvania Mountains HMA.

Creation of the above HMAs would provide useful management tools to assist in the protection of important wildlife species such as: the Black Toad (Bufo exsul), Chukar Partridge (Alectoris chukar), Mule Deer (Odocoileus hemionus), Desert Bighorn Sheep (Ovis canadensis nelsoni)_and others.

It is important to note that the boundaries of the five HMAs overlap to varying degress with the following wilderness Study Areas: White Mountains (WSA 103), Sylvania Mountains (WSA-111), Last Chance Mountains (WSA-112), Piper Mountain (WSA-115), Saline Valley-WSA 117, and North Coso Range (WSA131). With regard to these six WSA's, the BLM's preliminary wilderness recommendations in the CDCA include only the saline Valley WSA for wilderness. It appears that a portion of the Cowhorn-Waucoba Habitat Management Area is within the recommended Saline Valley Wilderness. The other five WSAs are proposed for BLM or National Park wilderness in The California Desert Protection of 1987, (S. 7 and H.R. 371).

Section 4 (b) of the Wilderness Act (P.L. 88-577) requires that wildlife management activities in designated wilderness be performed in accordance with the so-called "minimum tool principle". Additionally, the Interim Management Policy for Lands Under Wilderness Review, or (IMP) discuss wildlife management activities in lands under wilderness review at $\mathrm{Ch}$. III (E). The fact that WSAs are effected by this amendment is not mentioned in the document, nor are the above-mentioned requirements. In planning wildlife management activities in these HMAs, the Bureau is urged to plan each action in accordance with the requirements of the IMP and the wilderness Act. 
Gerald Hillier

10 December, 1987

p. 3

Amendment 6 .

The Wilderness Society supports the classification of 2,164 acres of undesignated lands adjacent Red Rock Canyon State Park to Multiple Use Class L. Important raptor species including the Golden Eagle (Aquila chrysaetos), Prarie Falcon (Falco mexicanus), Barn Owl (Tyto alba) and Great Horned Owl

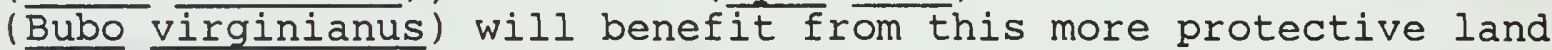
classification.

Amendment 7 .

We support the rejection of this amendment. The integrity of the Great Falls Basin ACEC is best served by rejection.

Amendment 8 .

We support the recommended changes in Multiple Use class.

Amendment 9.

The wilderness Society supports the development of a new component to the Desert Plan's Recreation Element that provides for special populations.

Amendment 10.

The Wilderness Society supports the rejection of Amendment 10. Denial of the change in Multiple Use Class in the Piute Valley Grazing Allotment will benefit wildlife and botanical resources in the Piute Range.

Amendment 11.

We support this amendment as it represents a logical and appropriate concentration of development activities.

Amendment 12 .

The Wilderness Society extends it's strong support of the proposed vehicle closure in the San Sebastian Marsh ACEC. 
Gerald Hillier

10 December, 1987

p. 4

The area supports outstanding natural resources including cultural history, wildlife resources including habitat for both an endangered species, Desert Pupfish (Cyprinodon macularius) and three candidate species; Flat-tailed Horned Lizard (Phrynosoma mcallii, Colorado Desert Fringe-toed Lizard (Uma notata), and the San Felipe Leopard Frog (Rana cf pipiens).

Additionally, the ACEC supports 107 bird species and several important habitats provide critical wildlife habitat in the ACEC.

Thank you for incorporating our comments into the public record on the 1987 Desert Plan Amendments. Please retain our office on the mailing list for the final document.

Sineerely,

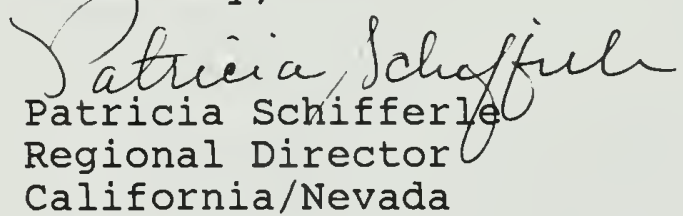




\section{$\underline{\text { Respose } 32-1}$}

The Coyote Mountains ACEC was established as a precaution to protect suspected cultural resource values. Deletion of this ACEC follows one prescription in the Desert Plan. According to Appendix C of the CDCA Plan, this ACEC would be subject to intensive cultural resource inventory, since existing data only contained two prehistoric sites. A recent 300 acre inventory revealed only sparse cultural materials considered unworthy of ACEC stature.

\section{Response $32-2$}

Althought most of the Coyote Mountains ACEC has been designated as open to OHV use for many years, it is relatively undisturbed owing to the difficult terrain which limits vehicle use. The BLM has permitted desert motorcycle races to cross the eastern portion of the ACEC. These were preceeded by field exams for cultural resources. Additionally, an enduro race was permitted this year across an existing course through the ACEC. 
State of Califormia

DEFAFTMENT OF PAFKS AND RECFEATION

High Desert District

4555 West Avenue b

Lancaster CA 9.550
The fiescurces Apency

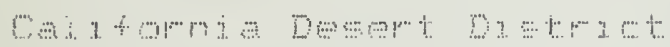

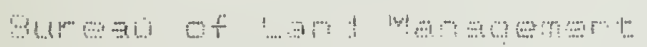

ATTH: Fir. Amencmento.

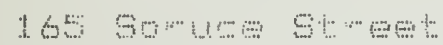

a ver $=1$ is:

ection

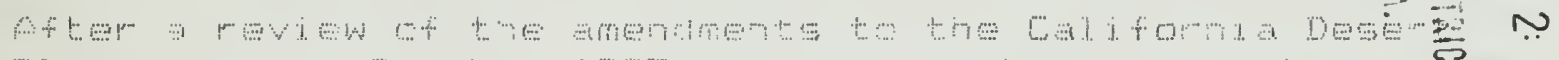

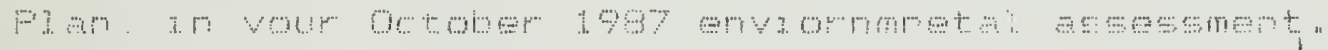

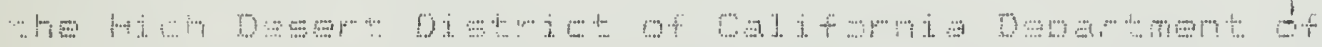

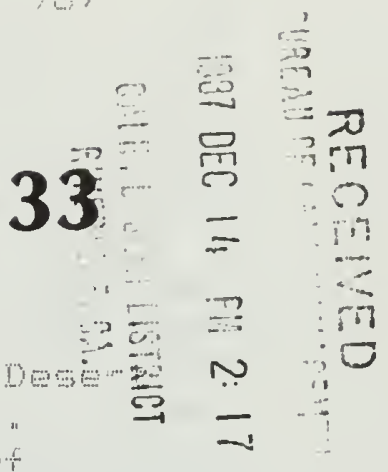

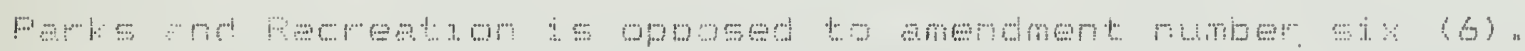

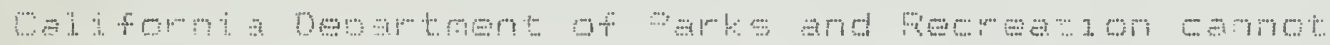

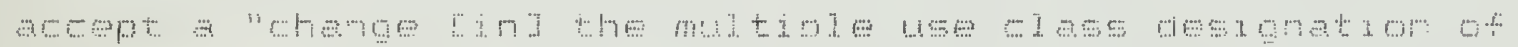

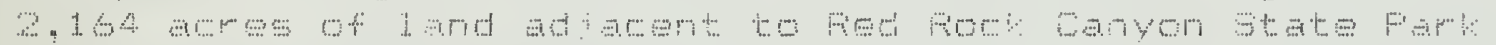

fyom "Umol as

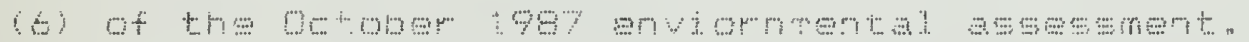

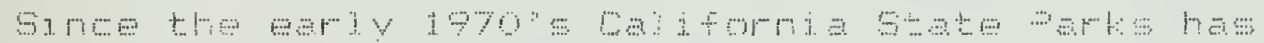

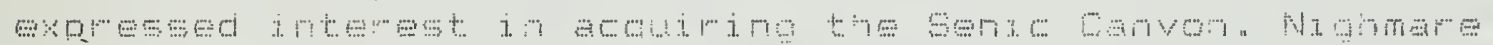

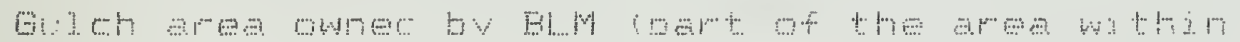

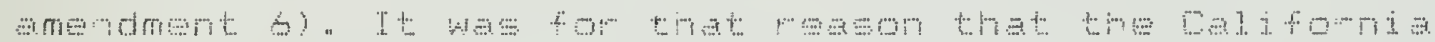

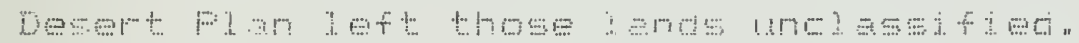

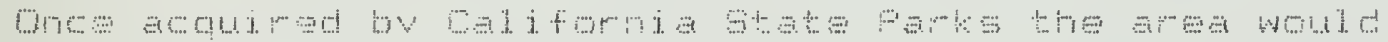

be operated as a otate park.

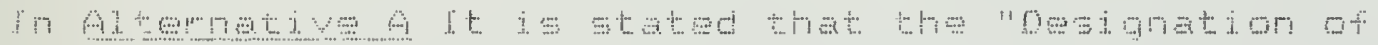

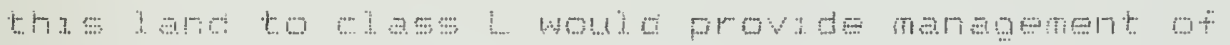

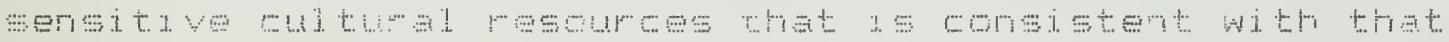

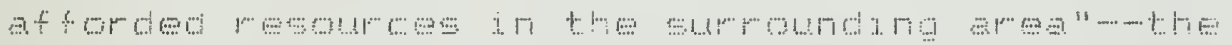

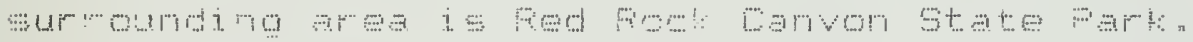

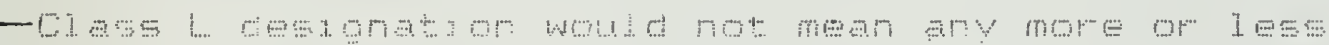

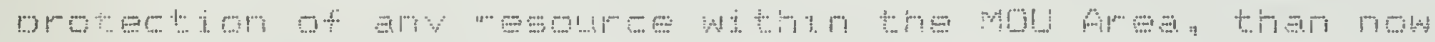

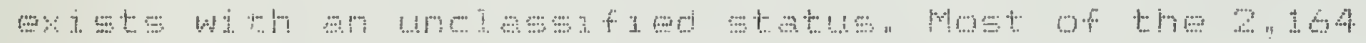

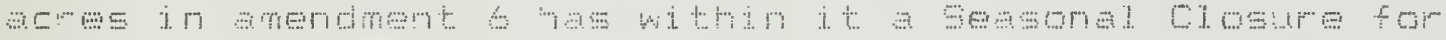

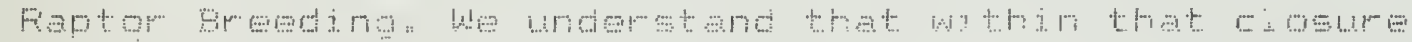

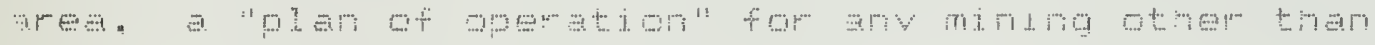

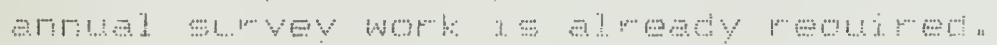

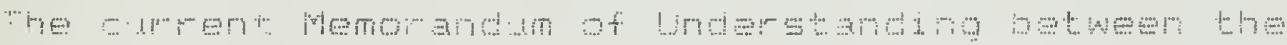

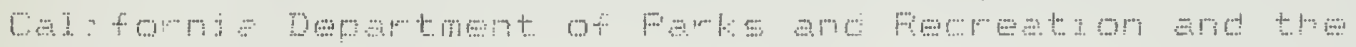

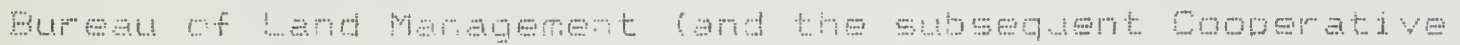
Managenent Agreement provides protection for most

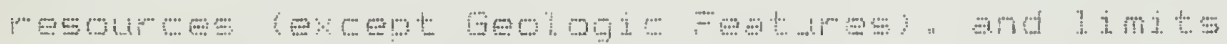
venicujer use to eoectied routes ourmo desoneted use

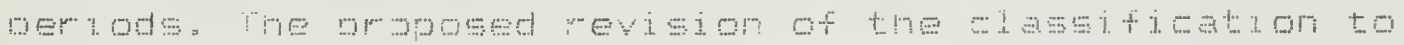

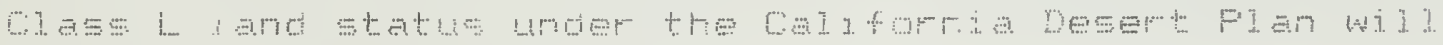
not provide any greater arotection for the ande in 


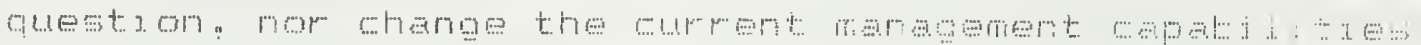
of the property.

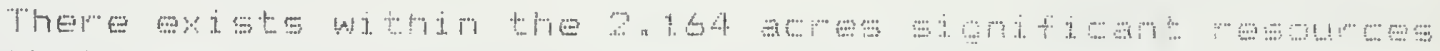

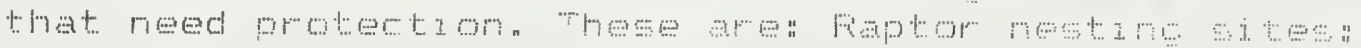

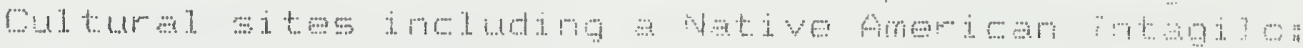

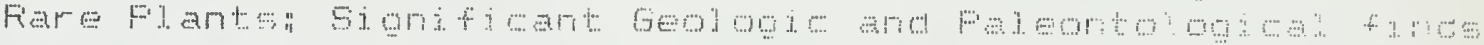

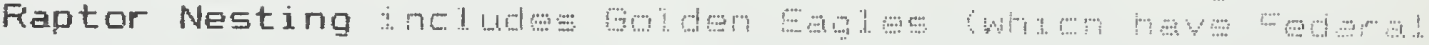

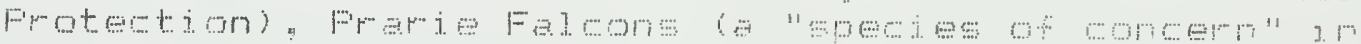

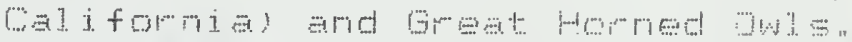

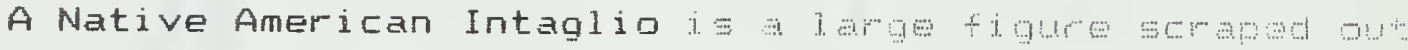

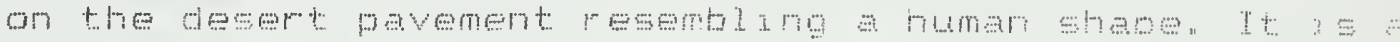

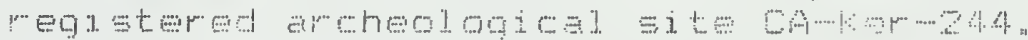

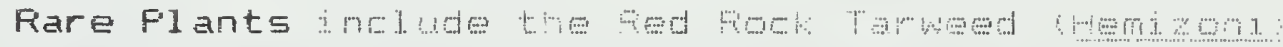

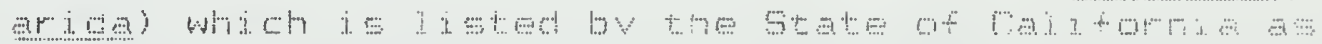

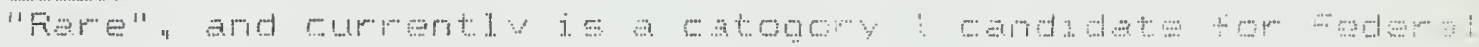

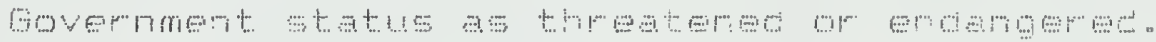

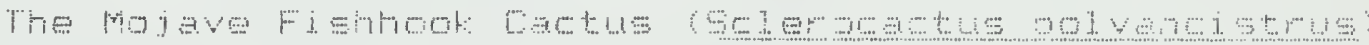

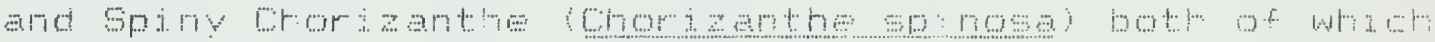

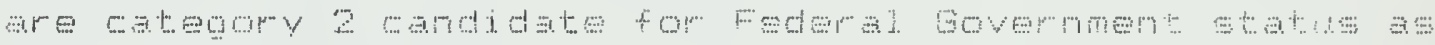

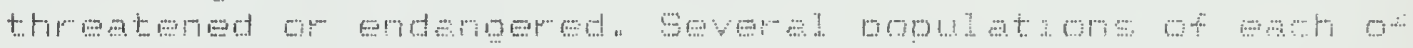

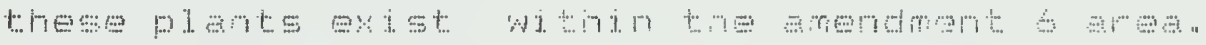

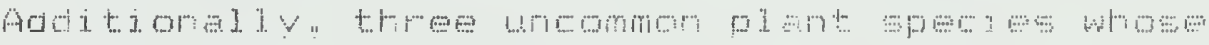

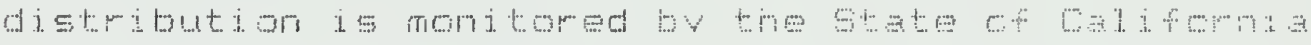

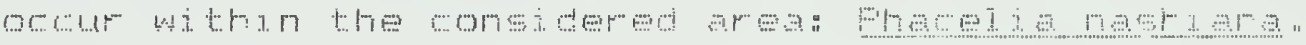

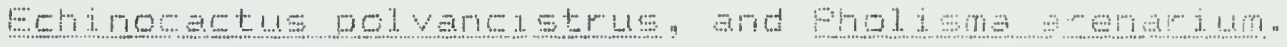

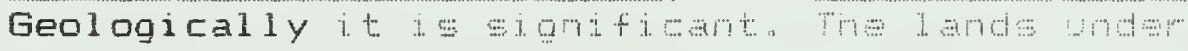

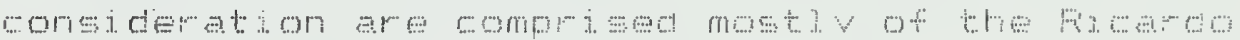

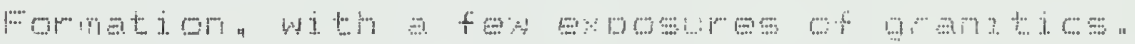

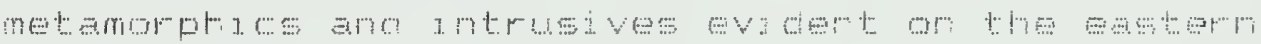

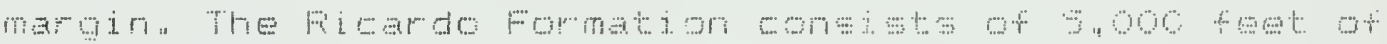

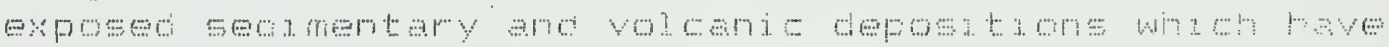

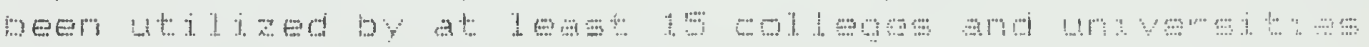

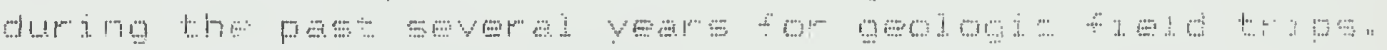

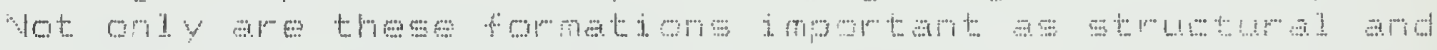

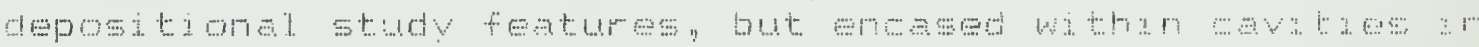

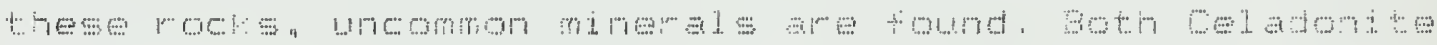

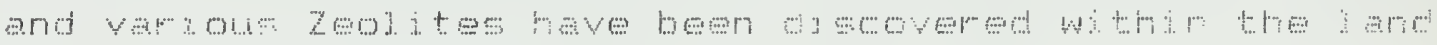

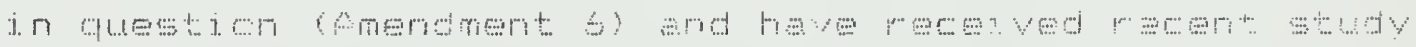

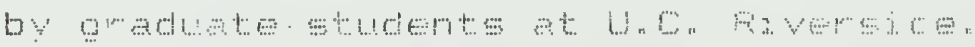

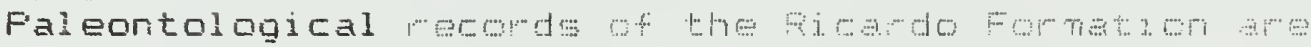

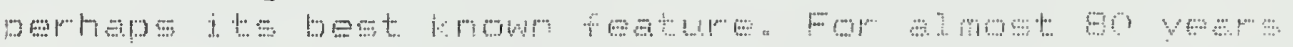

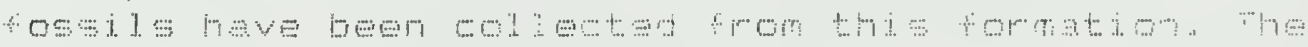

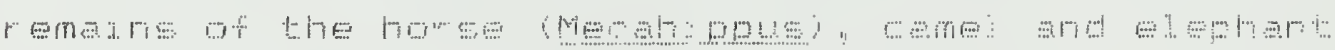

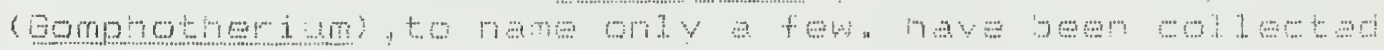

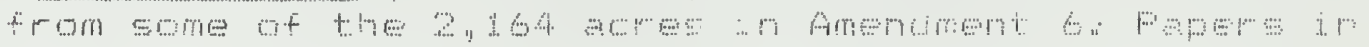

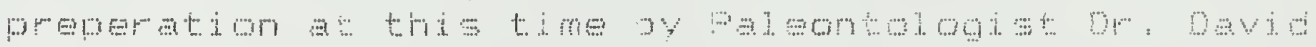
Wh

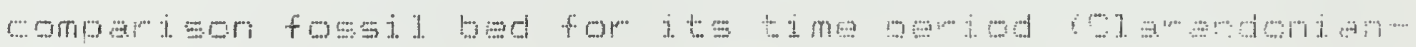

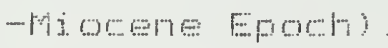

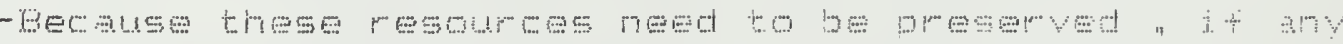
C. Area of Critical Enviornmental Coneern would be protected more. 
- (7) of the pe

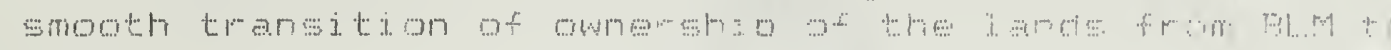

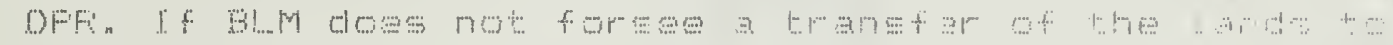

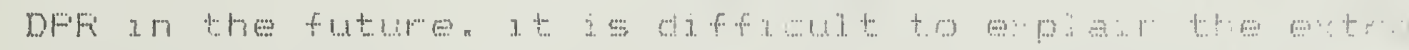

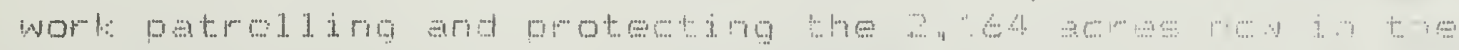
Mil.....

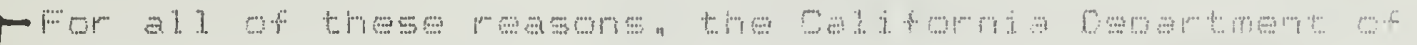
Fer

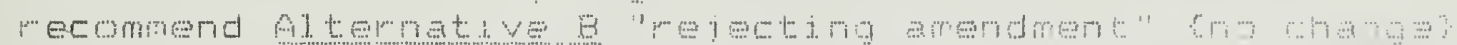

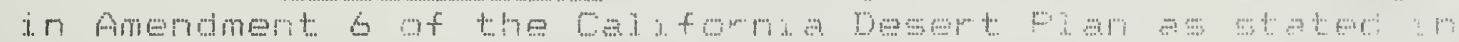

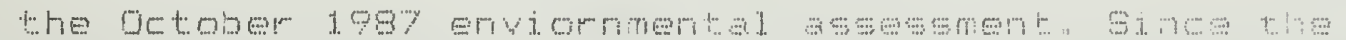

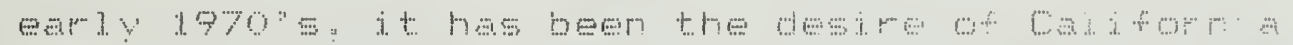

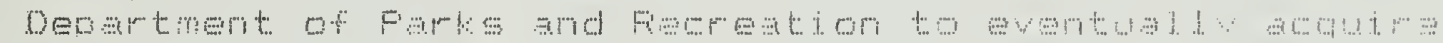

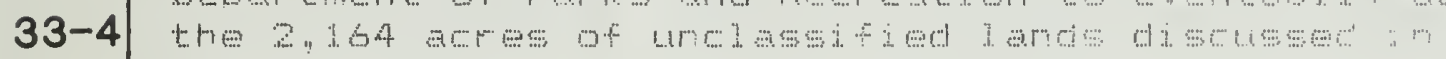

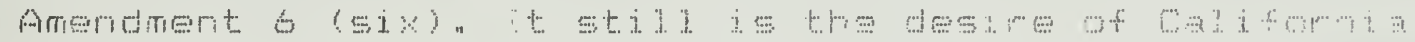

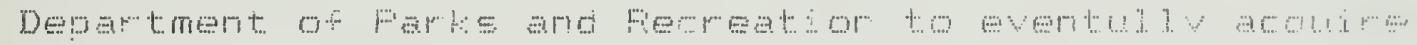

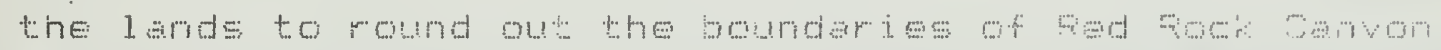

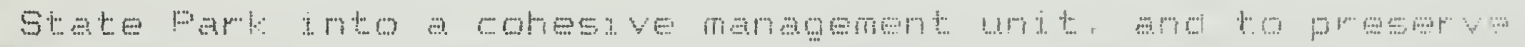
t..he land for post.er ity

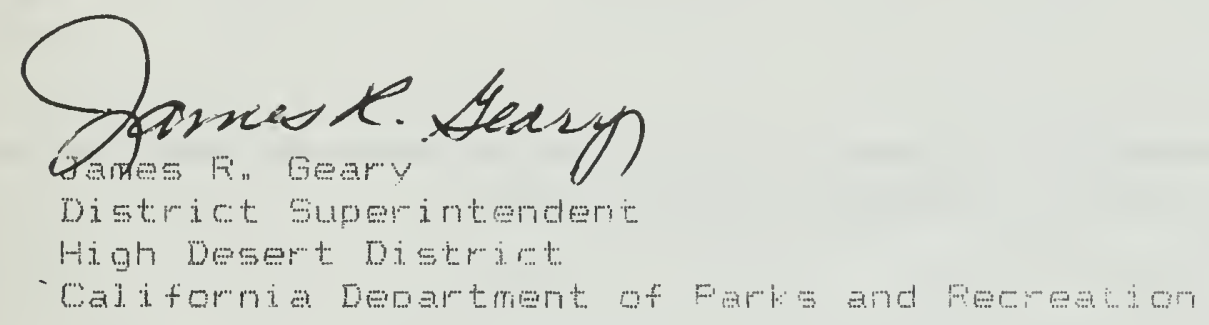


Response to High Desert District, Department of Parks and Recreation

Response $33-1$

The change in the multiple-use classification from "unclassified" to Class L will allow the BLM to apply the more restrictive management guidelines. Since the 2,164 acres are identified for retention, the Class L designation will provide for protective management of the resource values.

Response $33-2$

An ACEC designation is not justified at this time. Although the area does have notable resource values, the Class L designation will provide for protective management, particularly regarding mining, grazing and ORV use.

Response 33-3

The purpose of the MOU is to manage the public lands consistent with park management. The MOU does not address retention or future land transfer. See also Response 33-4 and letter 038, third paragraph.

\section{Response $33-4$}

In the future, the Department of Park and Recreation can submit an application under the R\&PP regulations for transfer of public lands. 


\section{तथ \\ DESERT \\ SURVIVORS}

December 8, 1987

$87 E A \quad 035$

Gerald E. Hillier, District Manager

California Desert District

Bureau of Land Management

ATTN: Plan Amendments

1695 Spruce Street

Riverside, California 92.507

Re: Proposed 1987 Plan Amendments to the California Desert Plan--Environmental Assessment

Dear Mr. Hillier:

Desert Survivors supports Bureau of Land Management recommendations for

all proposed amendments except numbers 4 and 5 . We support a slight extension of the proposed action in \#5 and take no position on \#4.

Areas of Critical Environmental Concern. Desert Survivors strongly supports the creation of new ACECS in West Mesa and Short Canyon, and the boundary adjustment to the Great Falls Basin ACEC (Ams. 1-3). We particularly support the vehicle closure in the San Sebastian Marsh ACEC as a positive action to protect the values of that area (Am. 12). The rejection of the Homewood Canyon land sale proposal similarly serves the long-term interest of the Great Falls Basin ACEC (Am. 12).

While we defer to the archaeologists who have conducted recent field research in the Coyote Mountains ACEC, we find it remarkable that cultural values deemed significant enough to warrant ACEC status in the 1980 Plan have failed to materialize in the face of an off-road vehicle conflict. Deferral of a final decision on this amendment might be appropriate (Am. 4).

Wildlife and grazing. We support the creation of Habitat Management Areas in the northern Mojave, but recommend that the Sylvania Mountains HMA be adopted as well to protect the wildlife of that remote yet accessible range (Am. 5). We support the rejection of the proposed Piute Valley Grazing Allotment classification change in favor of protecting the wildlife and botanical resources in the Piute Range (Am. 10).

Miscellaneous. Desert Survivors supports the Recreation Element goal of improving oppprtunities for enjoyment of the desert by special populations 
as a priority which speaks for itself (Am.9). We support Amendments 8 and 11 as appropriate concentrations of impairing activities.

Thank you for considering these comments.

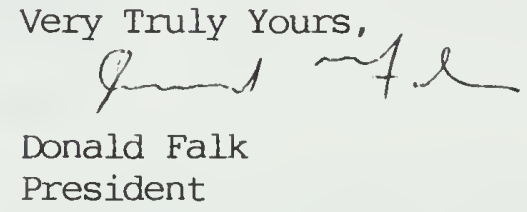


Response to Desert Surviors

Response $34-1$

See Response 32-1. 


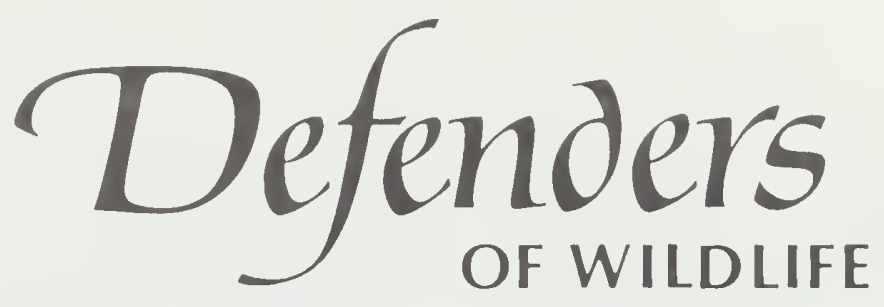

December 10, 1987

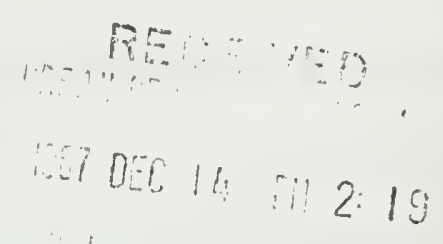

.....ilct

Gerald E. Hillier, District Manager California Desert District

U.S. Bureau of Land Management

ATTN: Plan Amendments

1695 Spruce Street

Riverside, California 92507

Dear Mr. Hillier:

Defenders of Wildife submits this letter as our comments and recommendations on the proposed 1987 Amendments to the California Desert Conservation Area Plan and Environmental Assessment.

Please consider our input, and include this letter in the appropriate public record.

We have reviewed the 12 recommended Amendments, and we generally concur with BLM's Preferred Alternatives for these Amendments. Indeed, we are pleased that many of these suggested Amendments would increase protection for important wildlife populations and habitats.

In particular, we support BLM's Preferred Alternatives for proposed Amendments Nos. 1, 2, 3, 5, 6, 7, 10, and 12. We concur with BLM's reasoning for its Preferred Alternatives.

We urge BLM to implement its Preferred Alternatives for these Desert Plan Amendments as soon as possible.

Thank you very much for considering our views.

Sincerely,

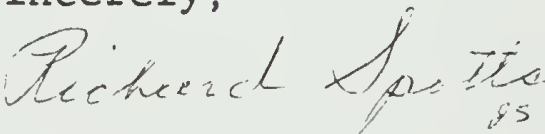

Richard Spotts

California Representative

Defenders of Wildlife

RS/js

cc: Ed Hastey, State Director

Interested parties 
OFFICE OF HISTORIC PRESERVATION DEPARTMENT OF PARKS AND RECREATION POST OFFICE BOX 942896 SACRAMENTO, CALIFORNIA 94296-0001

Mr. Gerald E. Hillier

Bureau of Land Management

California Desert District

1695 Spruce Street

Riverside, CA 92507

Dear Mr. Hillier:

RE: Proposed 1987 Plan Amendments to the California Desert Plan; BLM 871119 A-L

Thank you for requesting my comments on the above cited project. The additional information you provided in your letter of November 17, 1987, was very helpful in making my determination of effect. I concur with your determination that the proposed amendments to the California Desert Plan will have no effect on cultural resources.

While I am willing to concur in your determination of no effect, I would like to bring one point to your attention. Amendment No. 11, to establish a utility corridor, lack the kind of information necessary to make an informed decision. Based on discussions with your staff, I am willing to concur in your determination primarily on the basis that existing utility activities already occur within the proposed corridor.

I certainly agree with the premise behind corridor planning. The need to focus impacts is very important for sound management and reducing impacts to the full range of heritage resources.

However, the information provided in the document does not allow me to determine if there might not be another alternative that would have less of an effect on cultural resources. I would very much appreciate it if you could keep this in mind when future corridors are proposed. 
Once again, thank for requesting my comments. If my staff can be of any further assistance, please contact Dwight Dutschke at (916) $322-9624$.

Sincerely

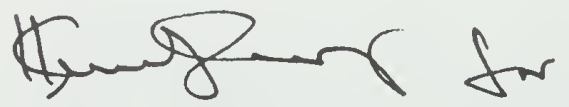

Kathryn Gualtieri

State Historic Preservation officer 


\section{DEPARTMENT OF THE AIR FORCE \\ HEADQUARTERS AIR FORCE FLIGHT TEST CENTER (AFSC) EDWARDS AIR FORCE BASE, CALIFORNIA 93523}

11 December 1987

\section{7}

Gerald E. Hillier, District Manager

California Desert District

Bureau of Land Management

ATTN: Plan Amendments

1695 Spruce Street

Riverside, California 92507

Dear Mr Hillier:

The Air Force Flight Test Center (AFFTC) at Edwards Air Force Base has reviewed the proposed 1987 plan amendments and environmental assessment and has no comments or concerns at this time. We would appreciate, however, a status report on the 1986 plan amendment recommending removal of burros from the Base proper.

Please send all information regarding the above to me at AFFTC/XRX, Edwards Air Force Base, California, 93523-5000. If we can be of any assistance in the future, please feel free to contact myself or Wendy Waiwood, of my staff, at (805) 277-3837.

The AFFTC appreciates the efforts of your agency in assuring compatible land uses throughout southern California.

Sincerely,<smiles>CCCCCCCON1CCCCC1</smiles>

ROBERT D. JQHSTONE, Chief

Plans and Policies Division 
Resources Building

1416 Ninth Street 95814

(9 16) $445-5656$

TDD (916) 324-0804

California Conservation Corps Department of Boating and Waterways Department of Conservation Department of Fish and Game Department of Forestry Department of Parks and Recreation Department of Water Resources
GEORGE DEUKMEJIAN GOVERNOR OF CALIFORNIA

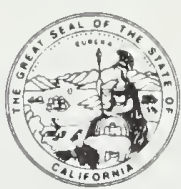

THE RESOURCES AGENCY OF CALIFORNIA SACRAMENTO, CALIFORNIA
Air Resources Board

California Coastal Commission California Tahoe Conservancy California Waste Management Board

Colorado River Board

Energy Resources Conservation and Development Commission San Francisco Bay Conservation and Development Commission State Coastal Conservancy

State Lands Division

State Reclamation Board

State Water Resources Control Board

Regional Water Quality Control Boards

\section{8}

$\mathrm{Mr}$. William Haigh

Bureau of Land Management

December 29, 1987

1695 Spruce Street

Riverside, CA 92507

Dear Mr. Haigh :

The State has reviewed the Environmental Assessment, Proposed 1987 Plan Amendments to the California Desert Plan, Southern California, submitted through the Office of Planning and Research.

Review of this document was coordinated with the State Lands Commission, the Colorado River Basin Regional Water Quality Control Board and the Departments of Conservation, Fish and Game, Health Services, Parks and Recreation and Transportation.

The Office of Historic Preservation in the Department of Parks and Recreation has commented directly to Mr. Gerald Hillier of your office by letter of December 17, 1987. In addition to those comments, the Department of Parks and Recreation (DPR) has comments on the proposed amendments as they relate to Red Rock Canyon State Park. DPR concurs with BLM's amendment 6 to change 2,164 acres of unclassified land adjacent to Red Rock Canyon State Park to "Class L". The current Memorandum of Understanding between the State and BLM for that area reflects this classification.

The District Superintendent and Chief Ranger at Red Rock Canyon State Park have indicated that there are archeological sites within the area that should be protected under an Area of Critical Environmental Concern (ACEC) designation (i.e.: CEA KER-244) DPR's Southern Region archeologist is studying the area to determine a recommendation of specific sites.

The contact person for DPR on this project is James Doyle, Supervisor, Environmental Review Section, P.0. Box 942896, Sacramento, CA 94296-0001, telephone (916) 324-6421. 
Comments that the Department of Fish and Game has provided are attached for your consideration.

Thank you for providing an opportunity to review this document.

Sincerely,

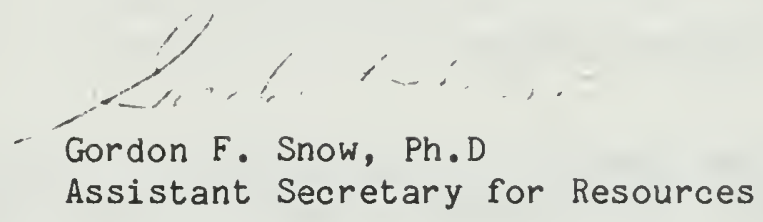

Att achment

cc: Office of Planning and Research 1400 Tenth Street

Sacramento, CA 95814

(SCH 87120401 ) 


\section{Memorandu m}

To

Honorable Gordon K. Van Vleck

Date

December 21,1987

Secretary for Resources

1416 Ninth street

Sacramento, CA 95814

Attn: Gordon F. Snow,

Projects Coordinator

$38 A$

From : Department of Fish and Game

Subject: Proposed 1987 Plan Amendments, California Desert Conservation Area - Bureau of Land Management (BLM), SCH 87120401

The Department of Fish and Game (Department) has reviewed the Draft Environmental Assessment (EA) for the proposed 1987 amendments to the California Desert Plan. The EA describes the environmental effects of accepting or rejecting each of the 12 proposed amendments accepted by the BLM for review. We have comments on the following amendments:

Amendment 1, Designate an ACEC for Wildlife, Botanical, and Cultural Resources in the West Mesa Area of Imperial County.

The Department supports BLM's decision to accept this amendment because such a designation will increase the protection of flat-tailed horned lizard habitat and other desert biological resources.

Amendment 5, Designate Six New Habitat Management Areas in Mono and Northern Inyo Counties.

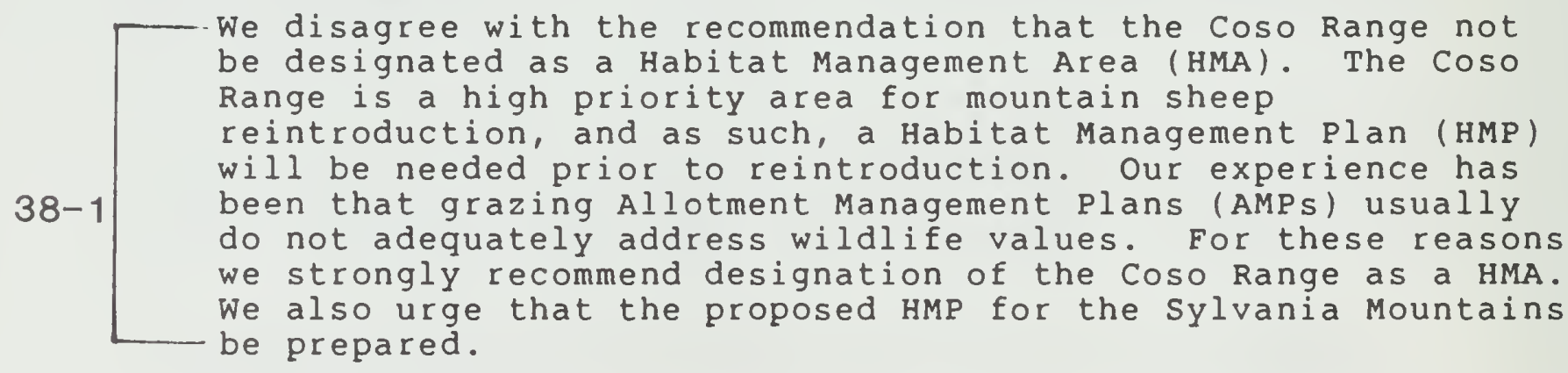

Amendment 8, Change T 12S, R l6E, Section 6, from Unclassified to Class L West of Coachella Canal and Class I East of Canal.

The Department requests that the proposed amendment be denied because the changes in Multiple Use Class of this section would encourage increased public use of the biologically sensitive Mammoth Wash area. 
The Department continues to oppose increased public use of the Imperial Sand Dunes Recreation Area. This area supports both deer and desert tortoise populations which would be severely impacted if development and increased use were to occur.

Amendment 10, Change Piute Valley Allotment from Ephemeral to Ephemeral-Perennial, with a 720 AUM's, All Allocated to Cattle.

The Department supports BLM's decision to reject the proposed amendment. Rejection of this amendment and enforcement of the ephemeral status would result in a net beneficial impact on vegetation and wildlife resources of the area. Perennial grasses would increase and overall range conditions for wildlife would improve. If minimum forage production requirements for livestock are not met, livestock would not be allowed to graze. During periods of non-use, water being diverted from Piute creek for livestock use would remain in the stream, increasing the flow further downstream and expanding and enhancing riparian areas associated with this stream. This appears to be particularly true in the area owned by the Department.

Amendment 12, Change Vehicle Access Designation from "Limited to Approved Routes" to "Closed" in a Portion of the san sebastian Marsh ACEC.

The Department supports BLM's decision to accept the amendment (Alternative $A$ ). The Department and BLM have cooperated in the preparation of the San Sebastian Marsh

ACEC. One of the management prescriptions was closure of the area to all vehicle travel. This closure is important to the continued existence of sensitive plant species, and the Colorado desert fringe-toed lizard, the flat-tailed horned lizard, the San Sebastian leopard frog, and the state- and federally-listed endangered desert pupfish.

Table B-2, Amendments Dropped.

We have the following comments regarding BLM's decision to drop the proposed amendments:

Amendment 87-P-19-Prohibit All Grazing South of I-l0 in the Ford Dry Lake Allotment.

38- The Department disagrees with BLM's decision to not consider this amendment: elimination of domestic sheep grazing south of I-lo on the Ford Dry Lake Allotment. 

$\uparrow$ We request this issue be resolved in the habitat management plan being prepared for the Chuckawalla Mountains. We have provided BLM with extensive information relative to the 38-2 potential and existing impacts of livestock disease on bighorn sheep. Continuing domestic sheep grazing in this area may preclude effective management of bighorn sheep in the Chuckawalla Mountains. Therefore, the Department recommends against domestic sheep grazing in this area.

Table B-3, Amendments Deferred.

We have the following comments regarding BLM's decision to defer the following proposed amendment:

Amendment 87-P-17, Eliminate the Lazy Daisy Grazing Allotment for a Period of at Least Five Years.

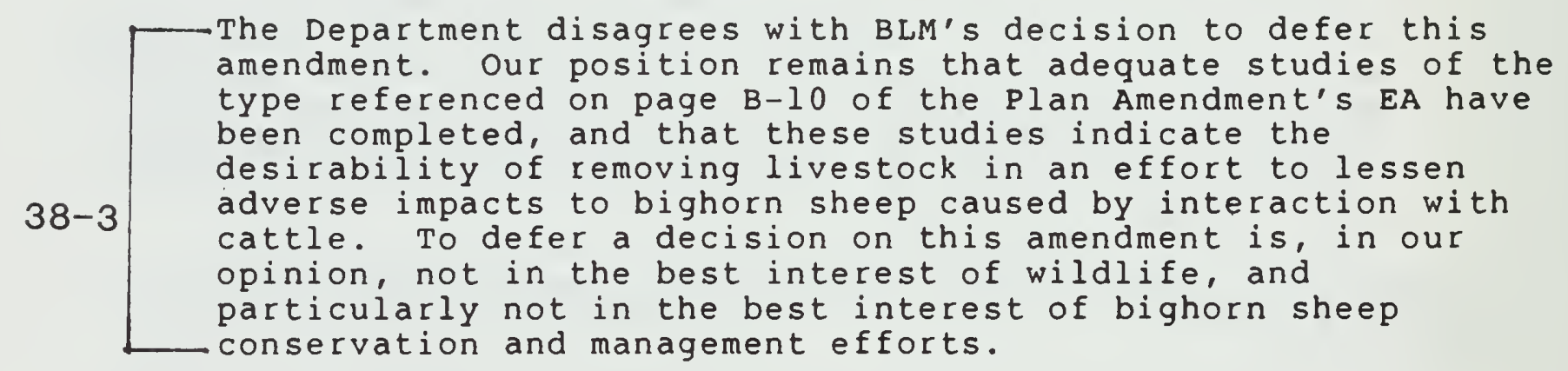

Thank you for the opportunity to review and comment on this EA. If you have any questions, please contact Fred worthley, Regional Manager of Region 5, at $245 \mathrm{~W}$. Broadway, suite 350 , Long Beach, CA $90802-4467$ or by telephone at (213) 590-5113.

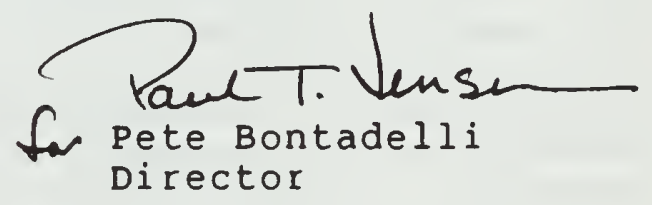


Response to Department of Fish and Game

Response to $38-1$

(left blank)

Response to $38-2$

The issue of grazing south of I-10 was deferred until the 1988 amendments and the habitat management plan for the Chuckwall Mountains is finish.

Response to $38-3$

(left blank) 
. 
APPENDICES

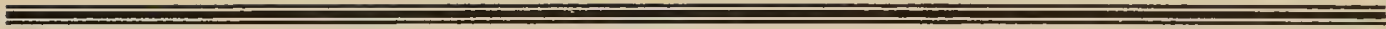



APPENDIX A

RESPONSE TO JOHN D. WEHAUSEN, Ph.D. 



\title{
United States Department of the Interior
}

\author{
BUREAU OF LAND MANAGEMENT \\ CALIFORNIA DESERT DISTRICT \\ 1695 Spruce Street \\ Riverside, California 92507
}

John D. Wehausen, Ph. D.

U.C., White Mountain Research Station

1417 Bear Creek

Bishop, CA 93514

Dear Dr. Wehausen:

Thank you for your thoughtful letter and proposal regarding cattle and bighorn sheep interrelationships in the 0ld Woman Mountains.

Cattle and sheep have been monitored to a limited extent over the past seven years, since the Desert Plan was adopted in 1980. The degree of this monitoring, together with studies of water and expansion of water, has not been to the extent we would have liked given the level of controversy associated with the 0ld Woman Mountains. But staffing and funding for the range management program just haven't been fully available or divertable from other allocations. We are still hopeful of completing these studies, as you have been able to do for the sheep population.

Your letter indicates your belief that current grazing started from a 1981 Plan Amendment. That really isn't quite correct. When the Plan was adopted in 1980, it is true that there was a decision to minimize grazing south of I-40. The specific objective adopted was to do things which would encourage bighorn sheep populations south of I-40. When faced with the fallout of that, however, Assistant Secretary of the Interior Guy Martin specifically directed in the decision document (in a personally handwritten caveat) to assure that the grazing leasee be worked with, and alternatives developed which would not unduly affect Mr. Blair's operation. The grazing allotment in the 0ld Woman Mountains is the only such allotment established.

The 1981 Plan Amendment was an attempt to set in place a plan for assuring some ultimate protection of a limited base while developing waters to help sheep and get the cattle off the higher parts of the mountain.

Your proposal to "experimentally eliminate livestock" for a five-year period would in effect permanently eliminate that use. There is just no alternate location where $\mathrm{Mr}$. Blair could take his operation for a five-year period. Now, while grazing is a privilege, and leases have terms and conditions affecting use, conflicts, and other matters, there is a due process procedure which must be followed in cancelling a lease, even temporarily. This is true even if the lease is being cancelled for wrong doing or a violation. Thus, were we to decide now to eliminate cattle, it well could not happen for as much as two to three years because of appeal rights and the allowance in the Code of Federal Regulations for continuation of activities while an appeal is pending. 
What I'm suggesting, then, is that all studies be done so that a decision, when reached, is fully defensible. You obviously would like, even with appeal rights, that decision process to be implemented this year. Unfortunately, I can neither do that legally nor in good conscience. I cannot "experimentally" put a livestock operation out of business without full cause. While I'm sorry that the data and studies contemplated by 1987 have not yet been completed, hopefully they will be within the next two to three years.

This is not an easy decision, however I believe it sound and just, and at this point, defensible. Currently we have ended grazing in the Clipper Mountains by eliminating that area from the larger part of the Colton Hills Allotment. This decision was also based on cattle-sheep competition. And that decision has been appealed to the Interior Board of Land Appeals (IBLA). Clearly that case will indicate a degree of legal standing. If we aren't sustained in that case, there probably is no way that grazing could be eliminated in the old Woman Mountains either temporarily ("experimentally") or permanently short of gross violation of the regulations or a drought condition reducing forage.

I'm sure I've not satisfied your concerns, but I do hope that you and others will continue to develop that data needed to equitably resolve this long standing issue.

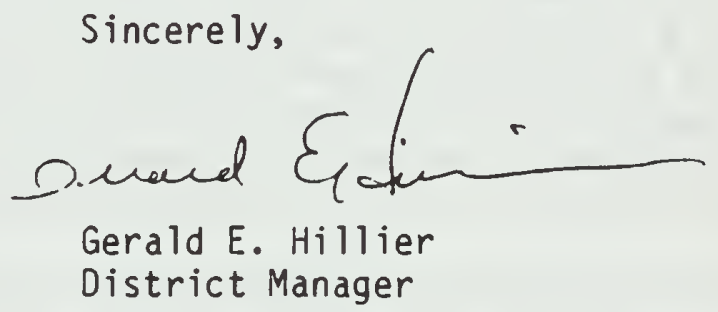


APPENDIX B

AMENDMENTS NOT CONSIDERF:D 


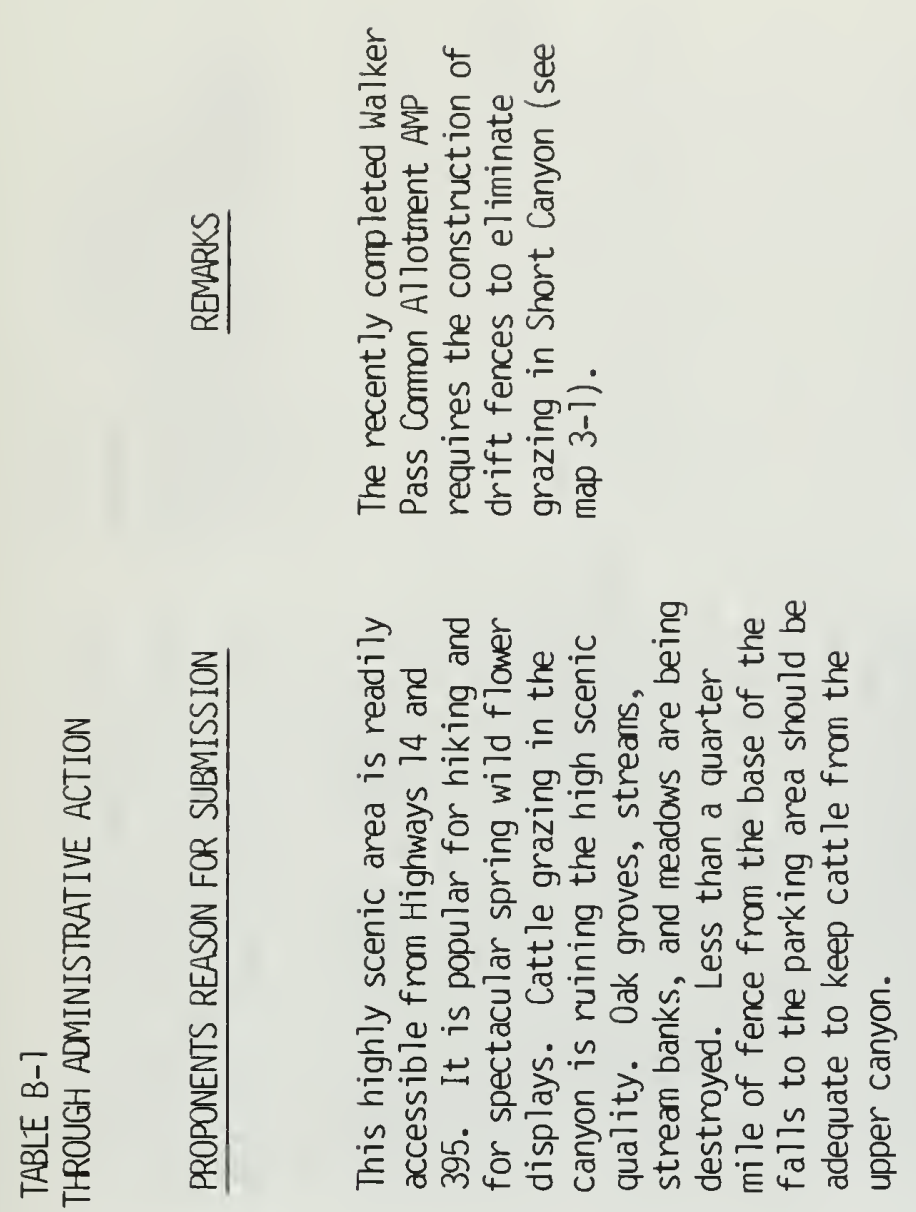

崫

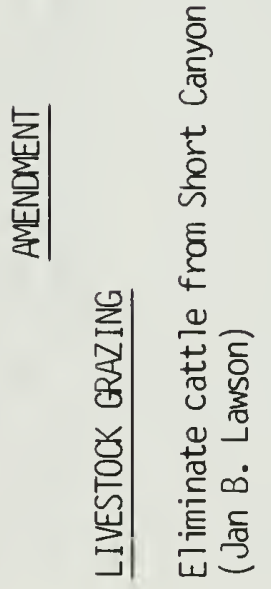

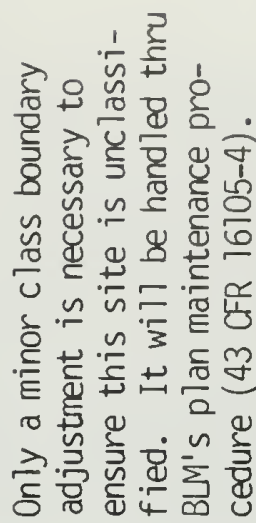

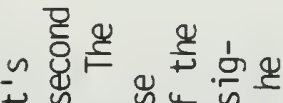

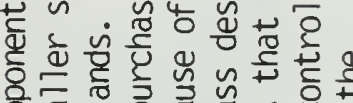
各攵

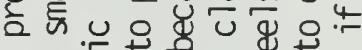
\&

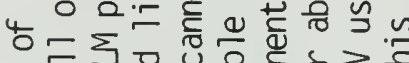

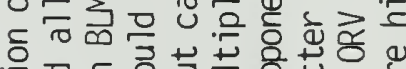

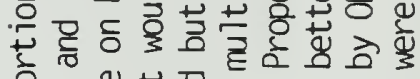

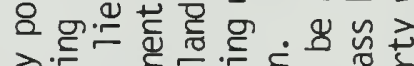

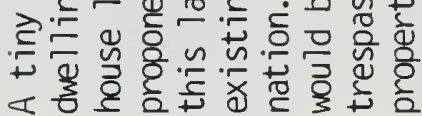

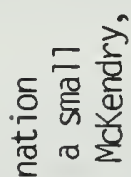

흥 ำ 产 $\bar{z}$

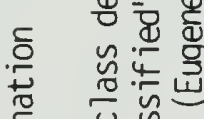
ธ兀

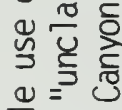

은요웡 ह $=$ 穷 站藏.

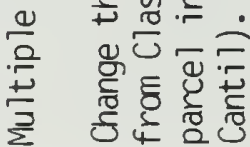

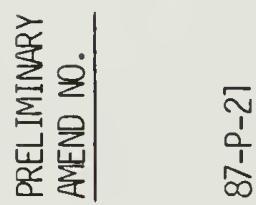

$\frac{\stackrel{2}{1}}{\frac{1}{1}}$ 


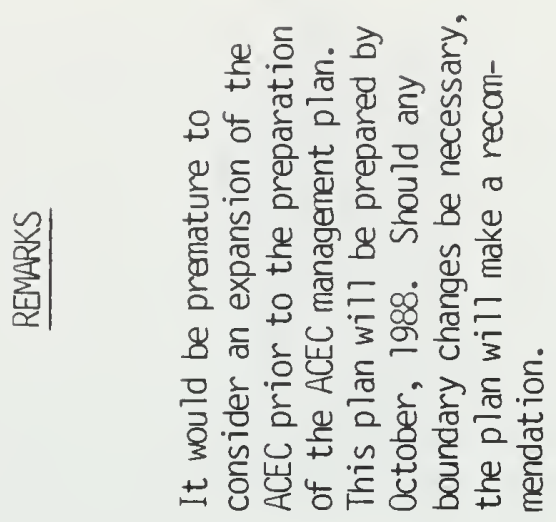

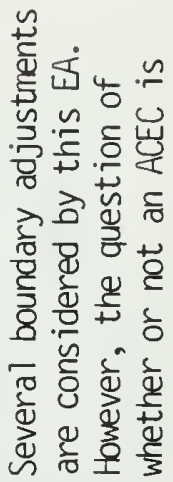
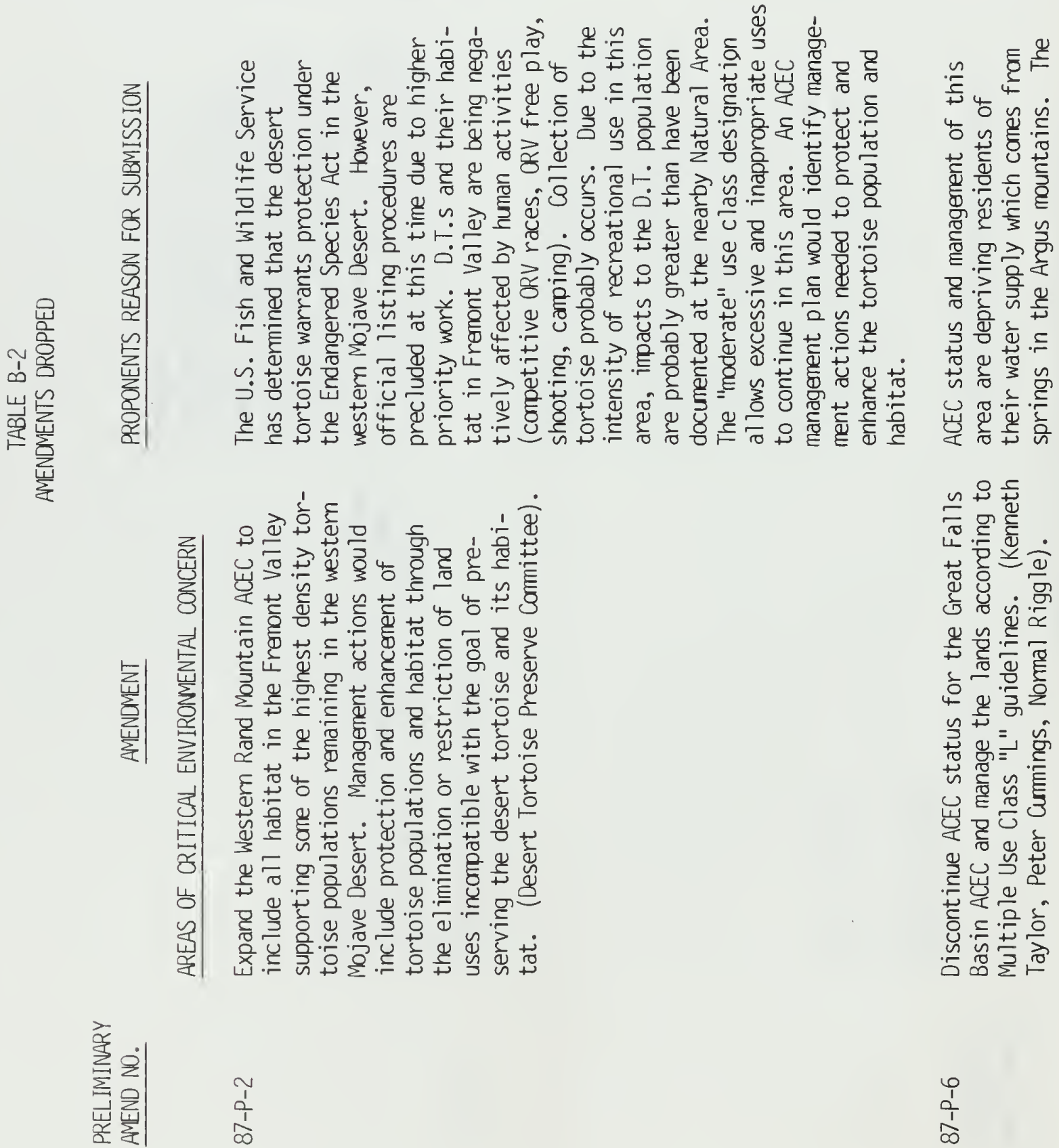

0
$\frac{1}{1}$
$\frac{0}{0}$ 


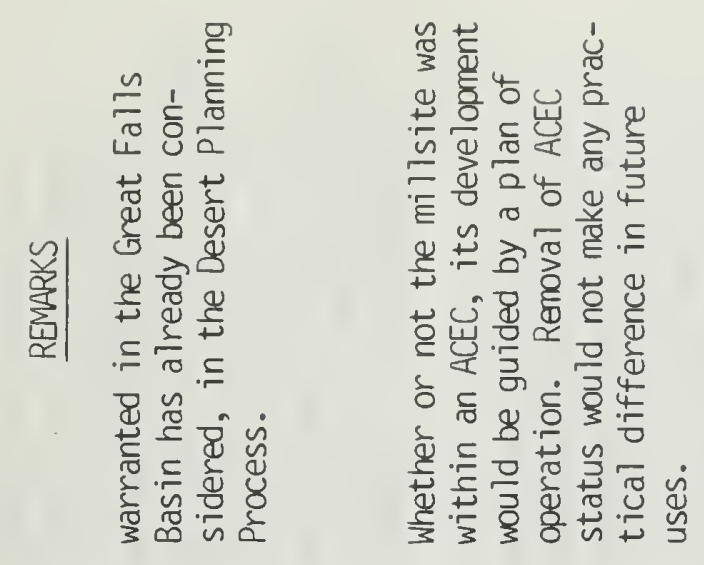

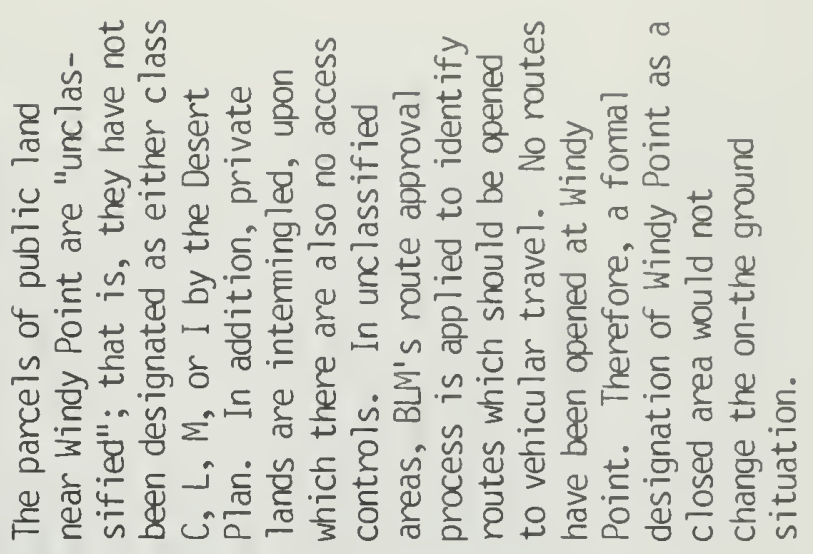
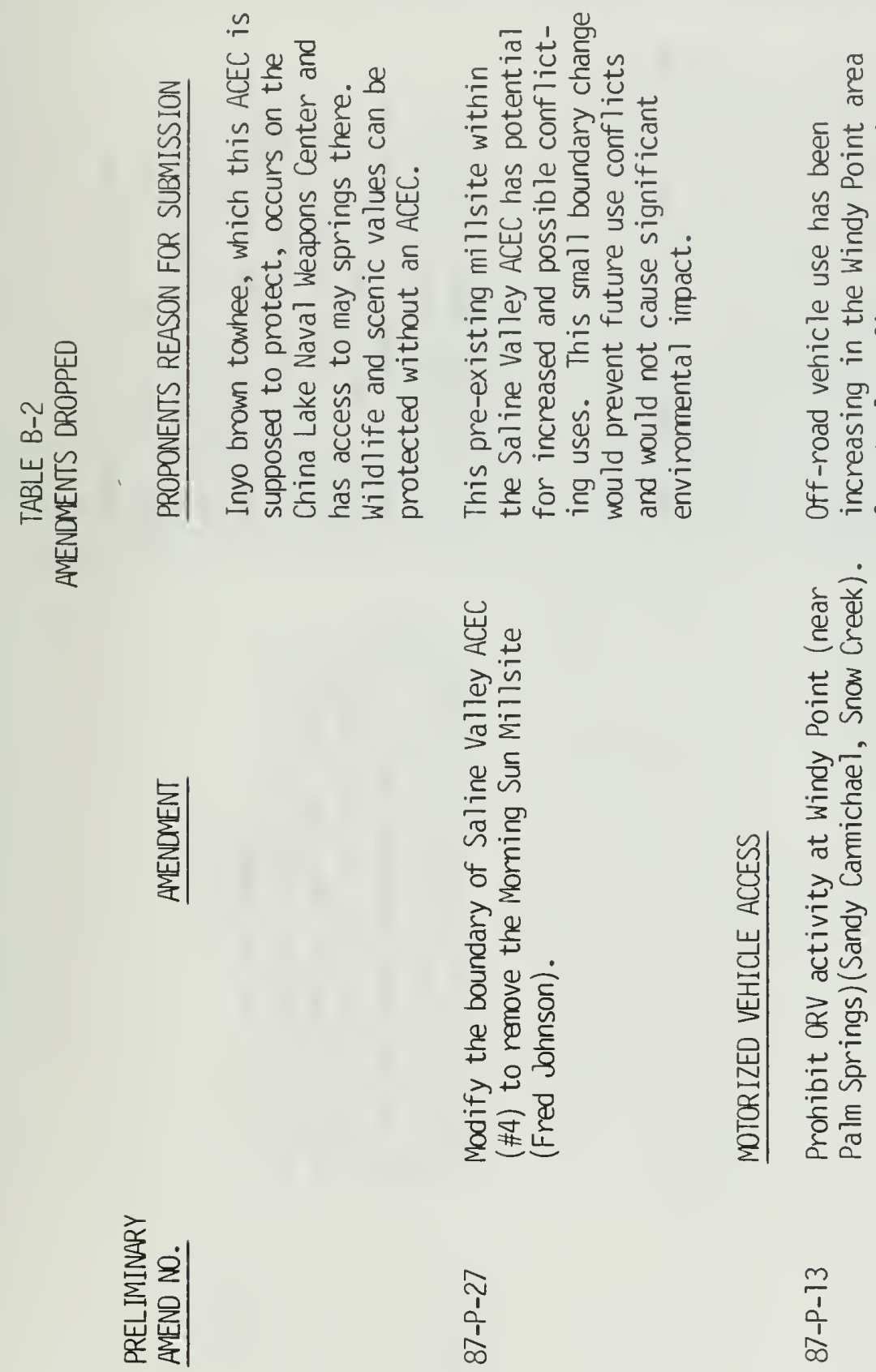

$\frac{\pi}{1}$

$\frac{m}{\frac{1}{1}}$ 


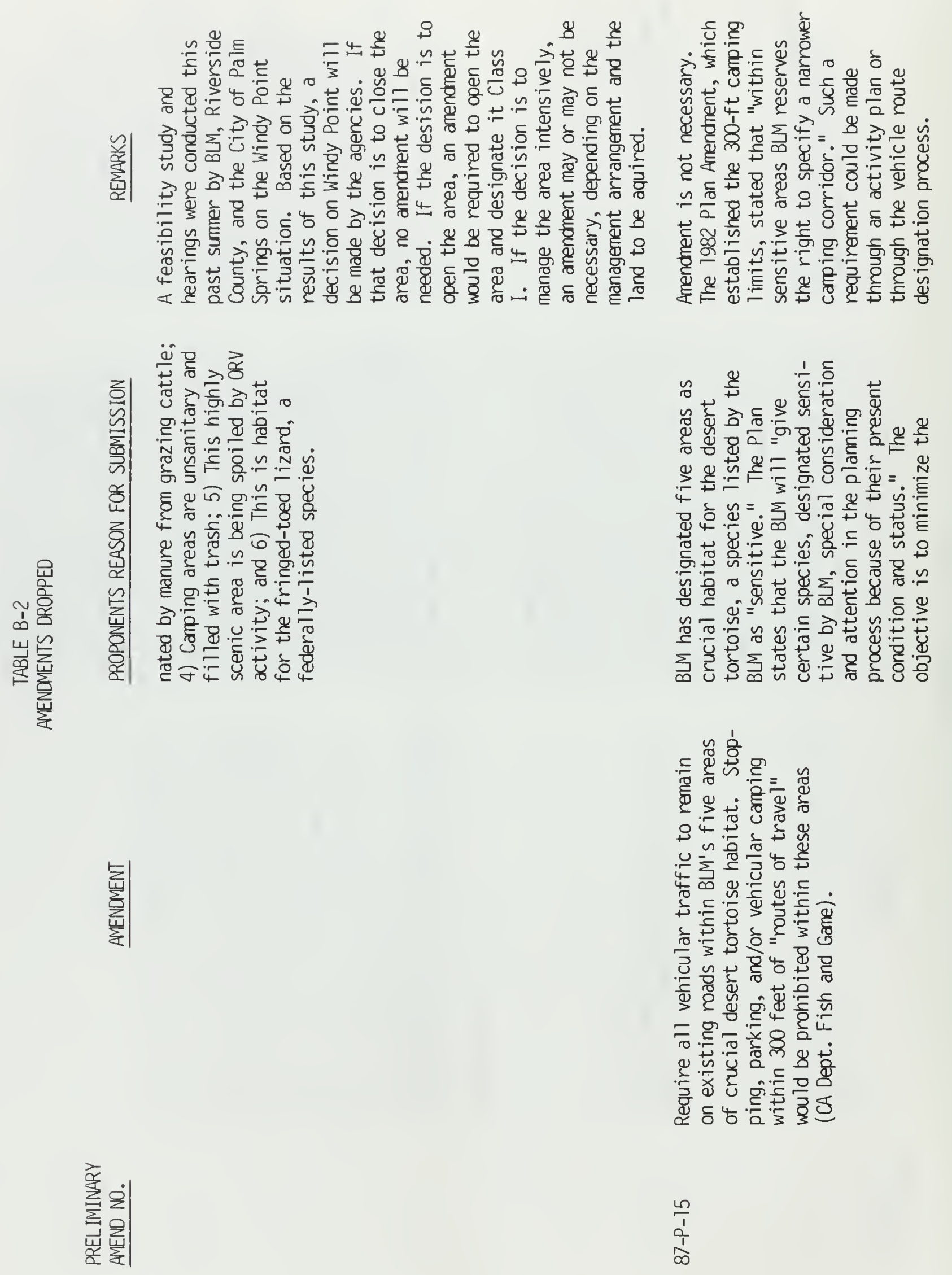


䍗|

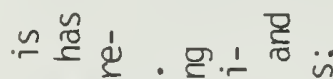

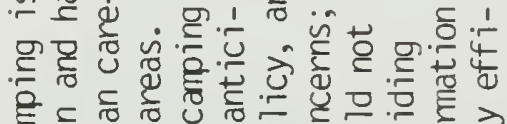

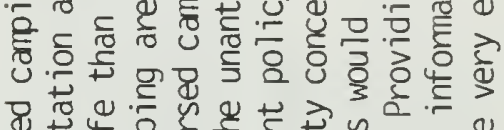

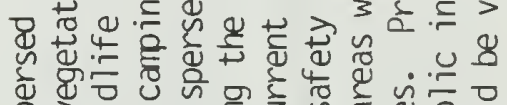

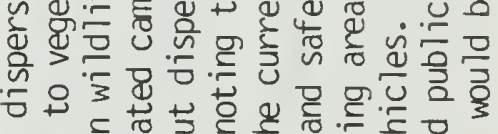
5.

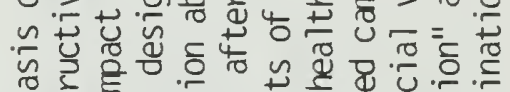

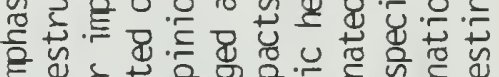
क

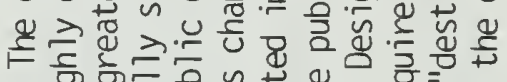

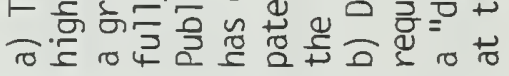

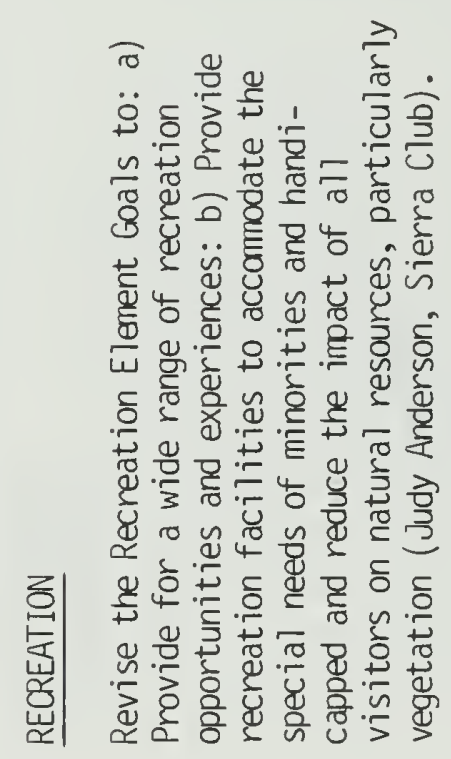

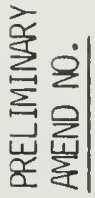

$\frac{6}{\frac{1}{1}} \frac{1}{\infty}$ 


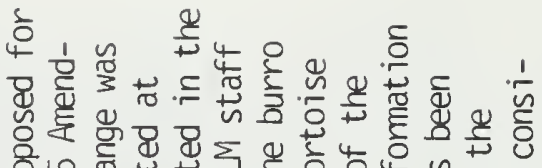

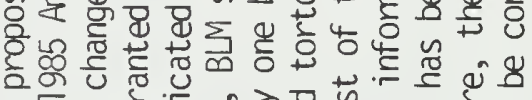

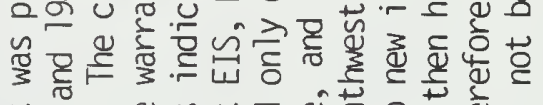

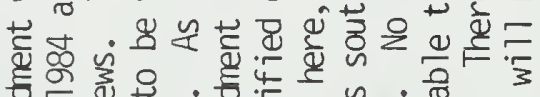

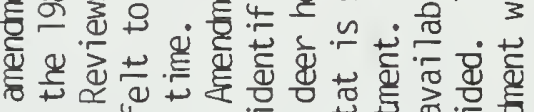

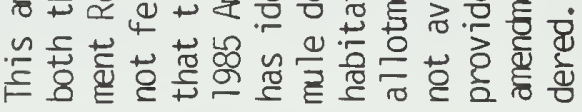

\&่ प्ن.

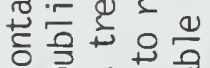

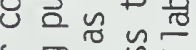

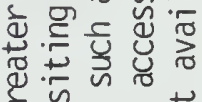
के. $\frac{1}{2} \backsim$ 항

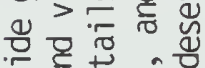

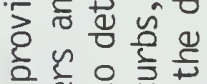

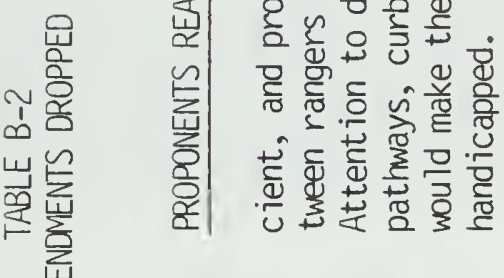

岕
离烎

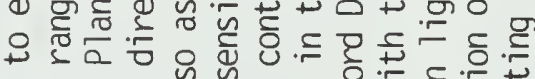

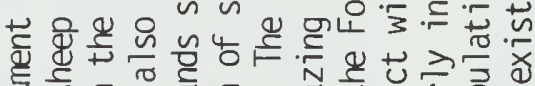

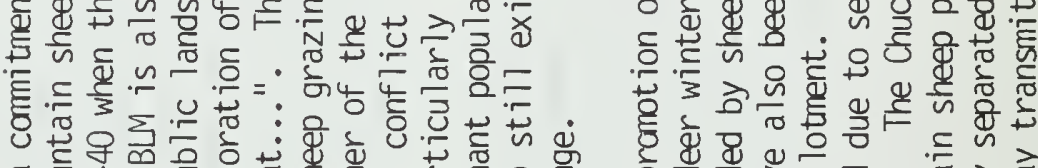
ช

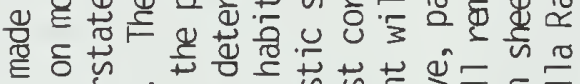

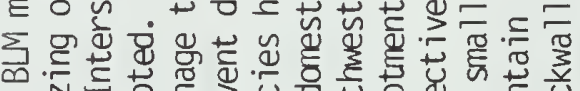

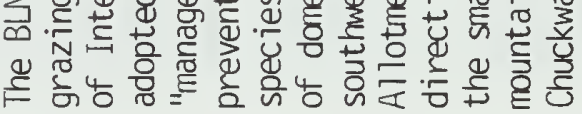

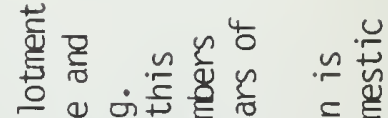

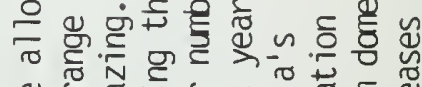

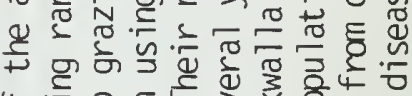

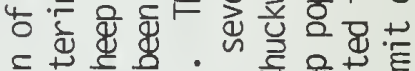

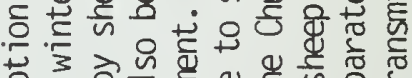
\& ह

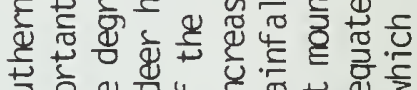

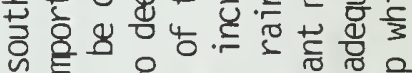

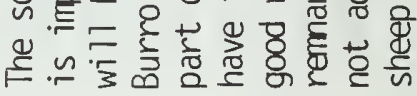

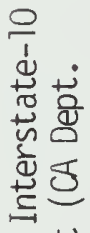

पे

兵告

몯

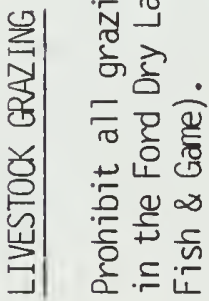

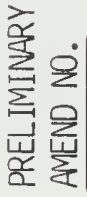

$\frac{a}{\frac{1}{1}}$ 
㩆

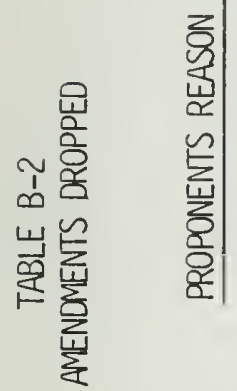

岕|

产是是|

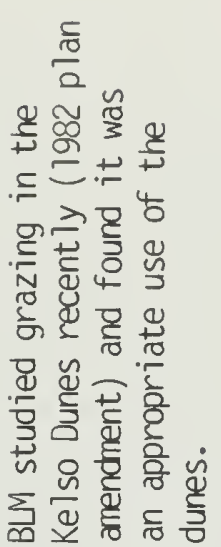

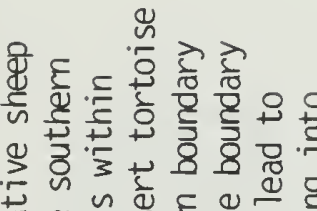

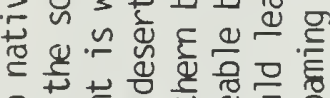

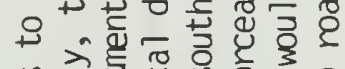

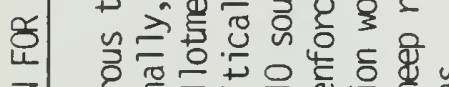

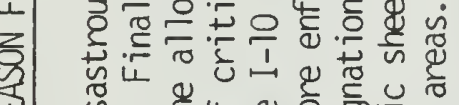

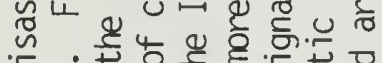

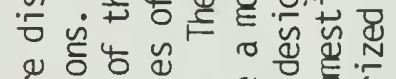

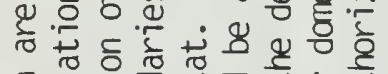
는 $\frac{0}{3}$.

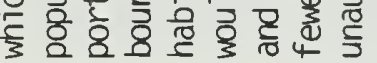

$\cong$

䒕

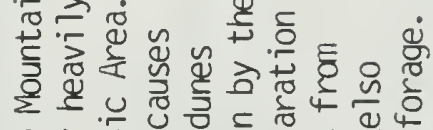

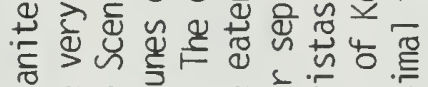

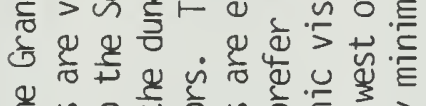

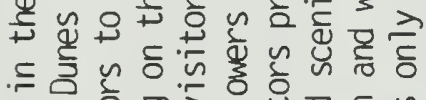
ฯ 우올 몰

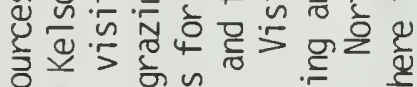
क्षे के थै : Q 巳

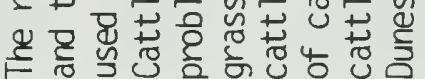

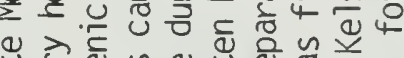

$\frac{4}{4}$

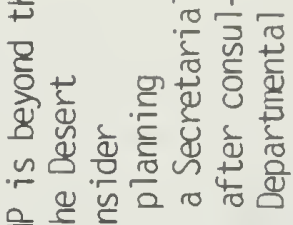

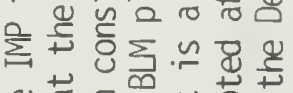

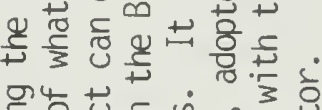

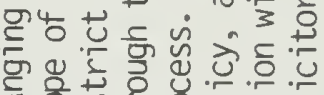
过然范岳 8

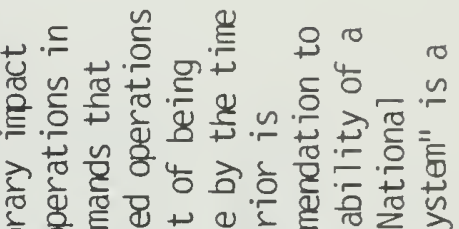

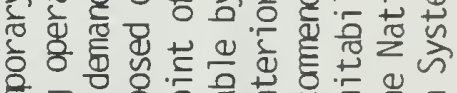
站. б.

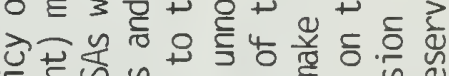

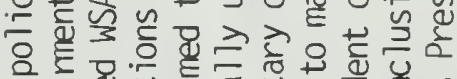

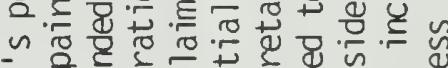

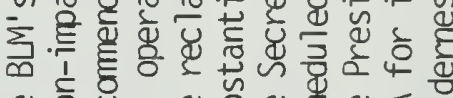

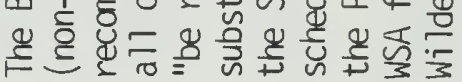

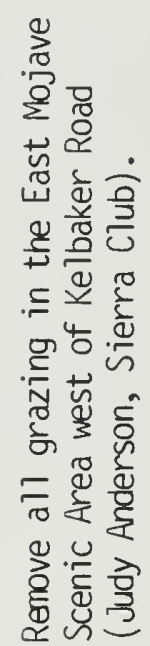

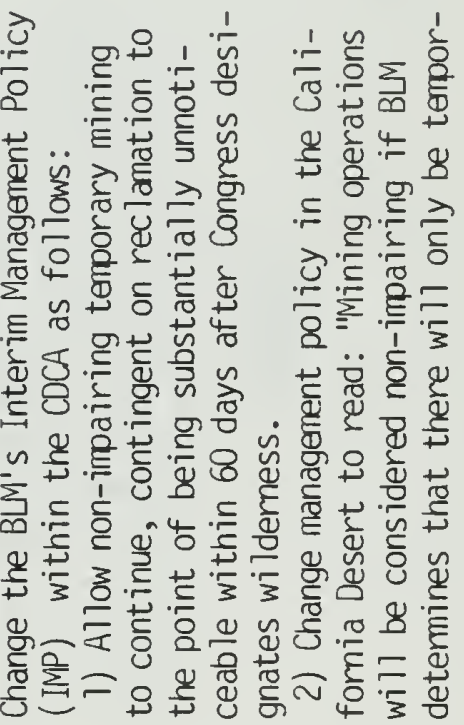

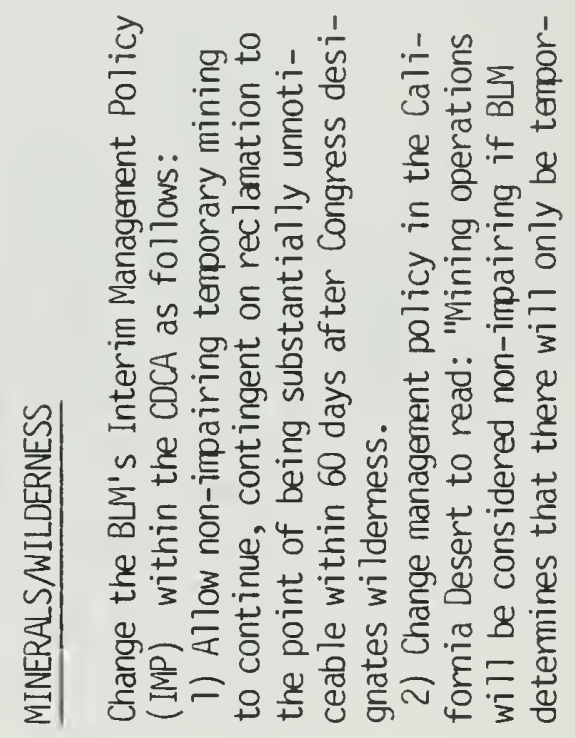

$\frac{\pi}{1}$ 
旁|
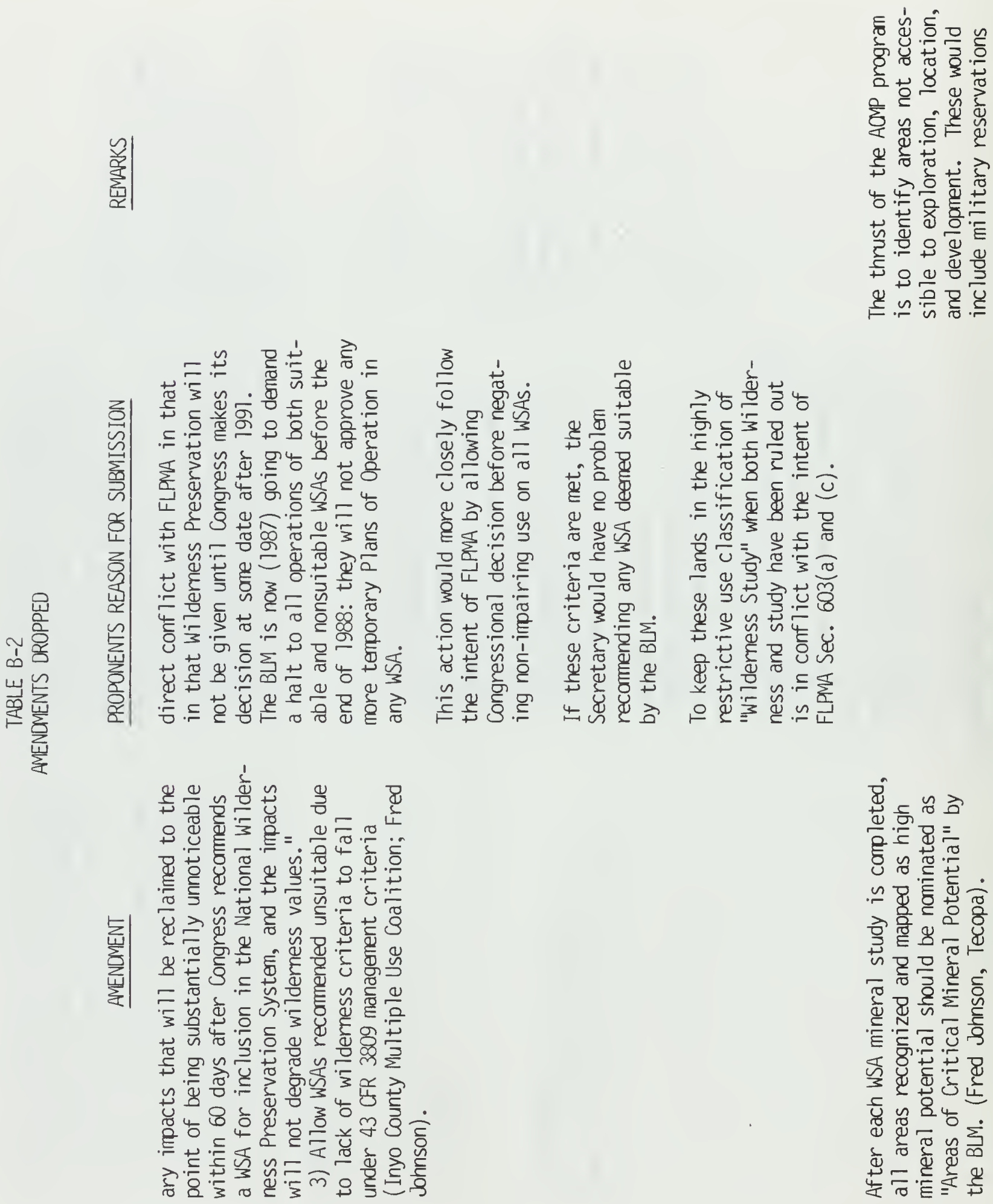

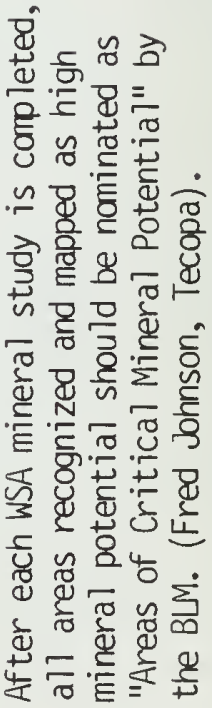

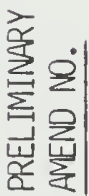

$\frac{0}{1}$
$\frac{1}{\infty}$ 

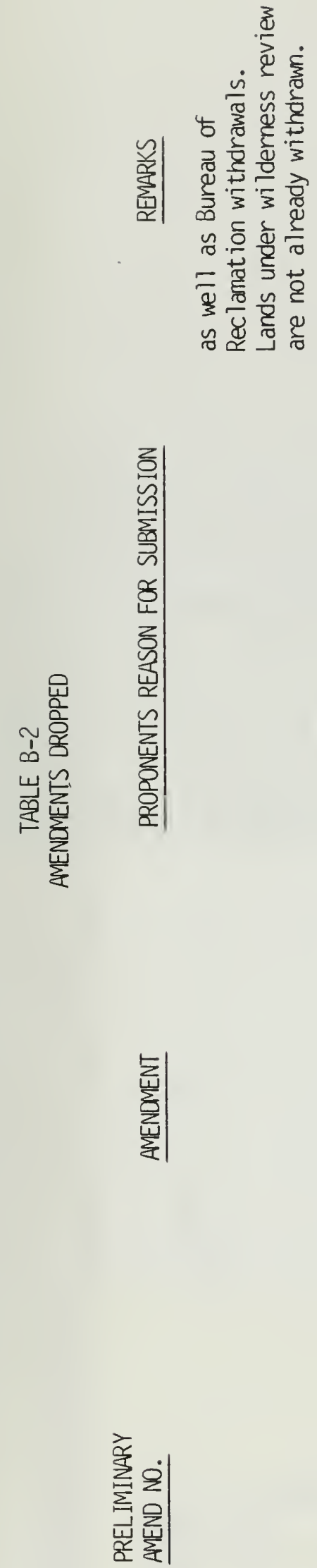


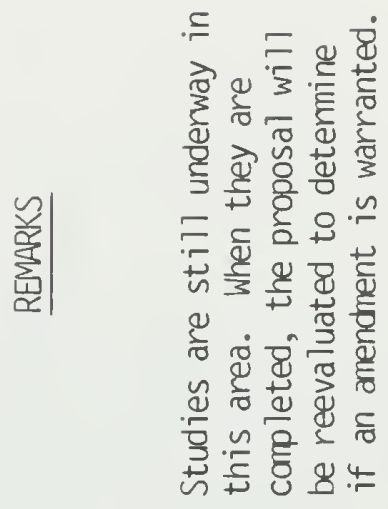

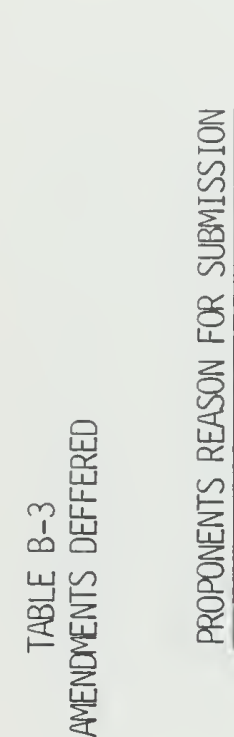

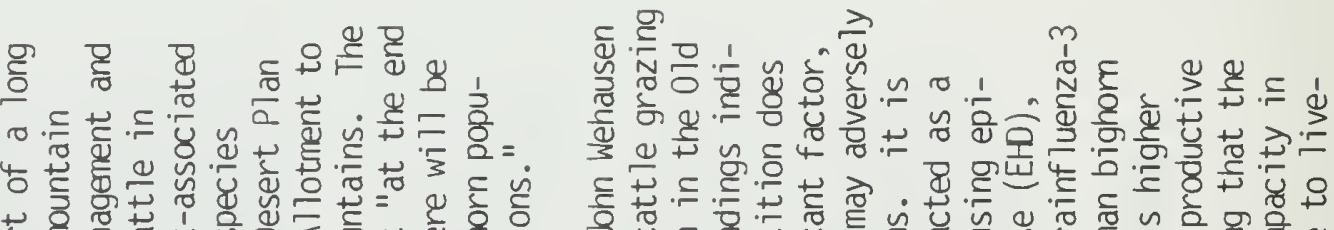

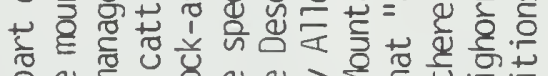
윤

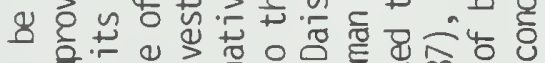

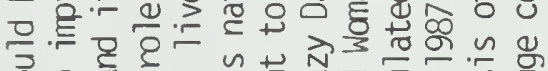
홍요

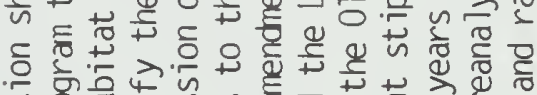

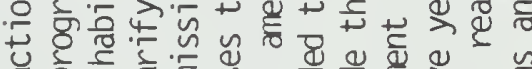

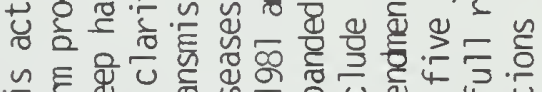

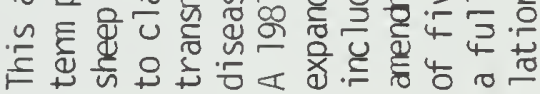

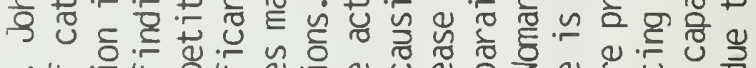

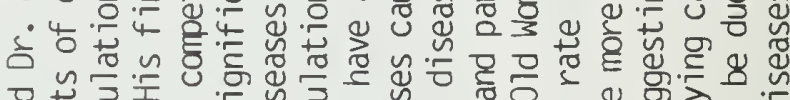

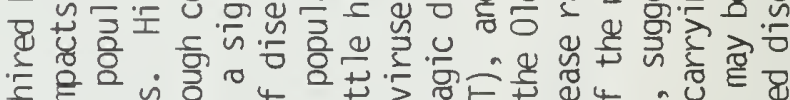

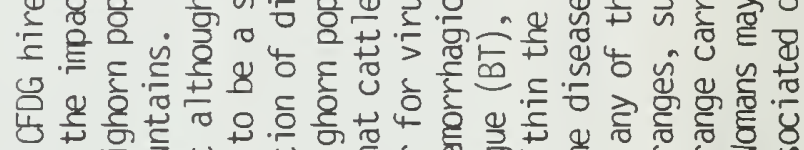

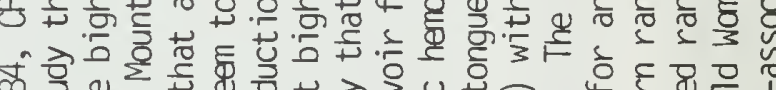

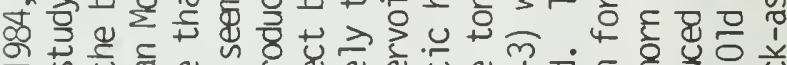
出市

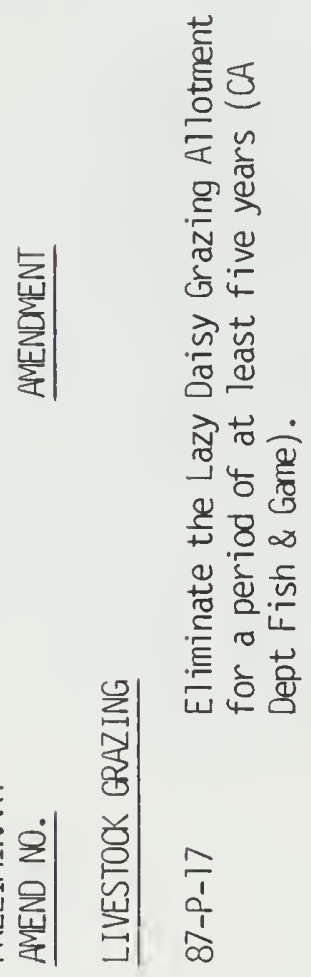



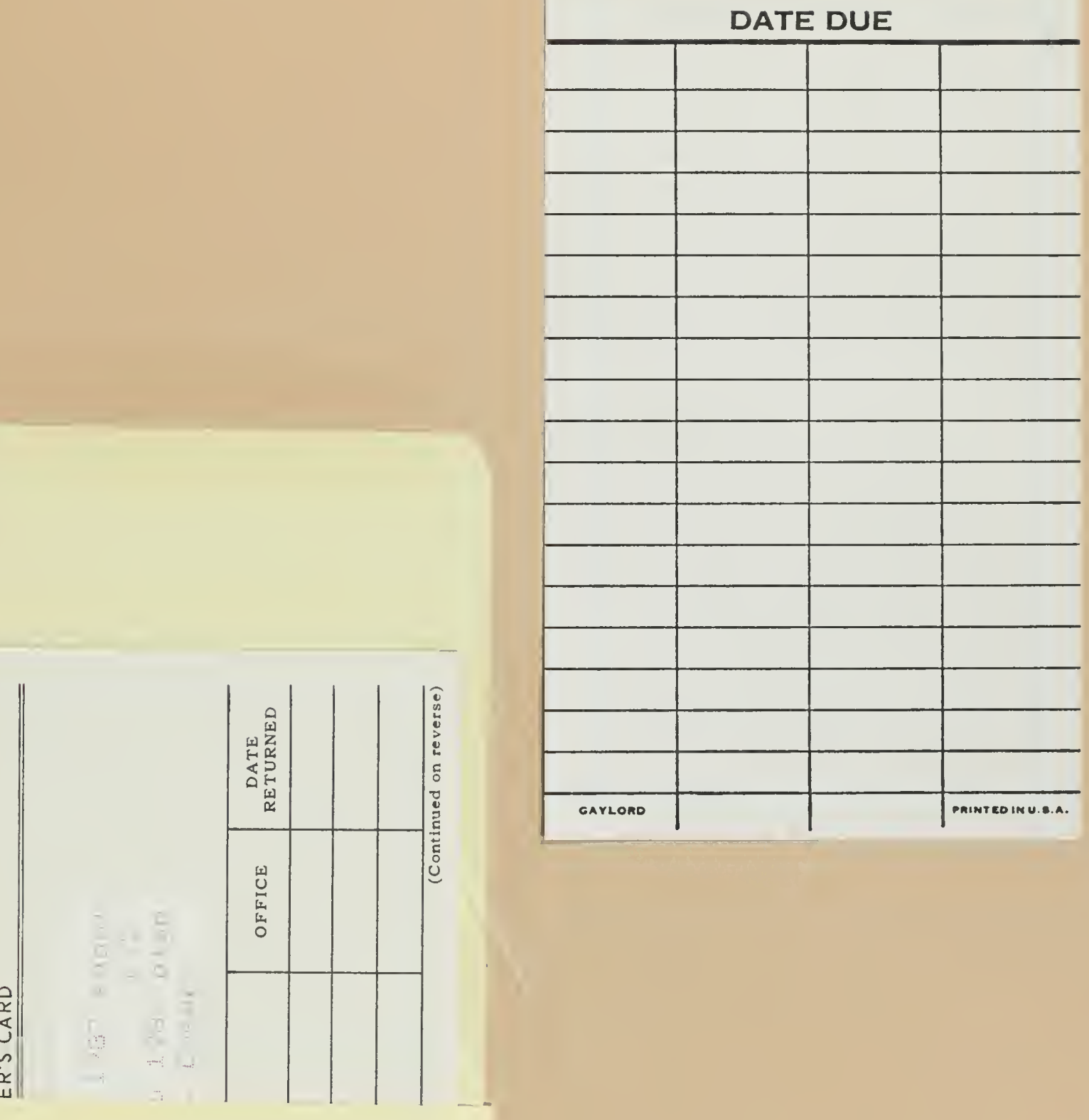

?

$\left\{\begin{array}{l}\text { BLM LIBSA } \\ \text { SC-32 } \\ \text { DE } 50 \\ \text { PE }\end{array}\right.$

$\left\{\begin{array}{lll}P & 0 \% & 01\end{array}\right.$ 
